\title{
Monitoring and Remediation of Environmental Aspects of Fe-rich Soils of Bahariya Oases and their Effects on peanut Quality
}

\author{
Sahar Mohamed Ismail; Sherine Shehata Marid and Doaa Taha Eissa \\ Soil physics and chemistry Department, Water Resources and Desert Soils Division, Desert Research Center, 1 El-Mataria St., Cairo, Egypt. \\ Corresponding authors: Sahar Mohamed Ismail \\ Soil physics and chemistry Department, Water Resources and Desert Soils Division, Desert Research Center, 1 El-Mataria St., Cairo, Egypt. \\ Email: dr.sahar.mohamedi@gmail.com
}

Received date: 15 July 2019, Accepted date: 28 September 2019, Online date: 30 September 2019

Copyright: ( 2019 Sahar Mohamed Ismail et al., This is an open-access article distributed under the terms of the Creative Commons Attribution License, which permits unrestricted use, distribution, and reproduction in any medium, provided the original author and source are credited.

\begin{abstract}
Bahariya Oases is a natural depression located in the western desert of Egypt. The whole region is under hot arid condition. Bahariya soils are rich in $\mathrm{Fe}$, which affects the color of peanut fruits and thus reduces its export value. Quantitative and qualitative monitoring of iron minerals and their chemical forms in Bahariya Oases beside of some organic and inorganic amendments to remove the Fe-red pigment from peanut pods and their validity for export were conducted. In this experiment, three inorganic treatments with three levels: gypsum (400, 500 and $600 \mathrm{~kg} / \mathrm{fed}$.), phosphogypsum $(400,500$ and $600 \mathrm{~kg} / \mathrm{fed}$.), sulphur $(100,150$, and $200 \mathrm{~kg} / \mathrm{fed}$.), and three organic treatments with three levels: rice husk biochar $(1,2,3$ ton/fed.), $\mathrm{K}$ - humate $(50,100$, and $150 \mathrm{~kg} /$ fed.) were incorporated into the top $30 \mathrm{~cm}$ of soil before planting. The soil samples were collected after the peanut harvest. X-ray diffraction, visible/near-infrared (VNIR) reflectance and thermal infrared (TIR) emission spectra for defining spectrally soil important mineral phases were carried out. $\mathrm{X}$-ray fluorescence spectrometer for identification of soil mineral composition was performed. Also fourier transform infrared (FTIR) spectra and characteristics of the used amendments were conducted. The surface morphology of the rice husk biochar sample by electron microscope scanning and the Brunauer, Emmett and Teller (BET) surface area was detected. Extractable soil-Fe, $\mathrm{Mn}, \mathrm{Zn}, \mathrm{Cu}, \mathrm{Ni}$ and Cd were determined. Pods yield $(\mathrm{g} / 100 \mathrm{~m} 2)$ and weight of 100 pods $(\mathrm{g})$ were measured. Also, a follow up the appearance of the red pigment or not in the all treatments was achieved. Total NPK contents in peanut shoot and grains and some heavy metals were determined. Data were statistically analyzed using analysis of variance adopting SAS software analysis. The results of the X-ray diffraction of soil sample revealed primarily iron minerals, goethite and tiny quantities of hematite and gangue minerals represented mainly by quartz, in addition to small quantities of halite and illite. Visible/near-infrared (VNIR) reflectance and thermal infrared (TIR) emission spectra of the soil samples indicated to dominance of crystalline Fe-oxides (hematite and goethite). Thermal Emission Spectroscopy indicated $\sim \mathbf{5 0} \%$ phyllosilicates (dominated by Fe-smectite), $\sim 11 \%$ carbonate, $\sim 11 \%$ quartz, and $\sim 10 \%$ Fe-oxides (combination of hematite and goethite). Also, results indicated that gypsum (600 kg/fed.), phosphogypsum (600 kg/fed.), sulphur (200 $\mathrm{kg} / \mathrm{fed}$.), $\mathrm{RH}$ biochar ( $3 \mathrm{ton} / \mathrm{fed})$ and sugar beet industry waste $(600 \mathrm{~kg} / \mathrm{fed})$ treatments exerted significant effect, while at the same time, caused increases in peanut pod quality, pod yield, 100-pod weights and absence of Fe-red color compared with the control. The applied soil amendments, except for K-humate decreased DTPA-extractable levels of Fe in the soil. Some soil amendments application under this study improved Fe-contaminated soil and reduced the potential environmental availability of soil-Fe.
\end{abstract}

Keywords: Baharyia Oases, Peanut, Fe-rich soil, organic amendments, inorganic amendments, red pods, iron minerals

\section{INTRODUCTION}

The Bahariya Oases is about 320 kilometers southwest of Giza governorate (Figure 1). There are extensive $\mathrm{Fe}^{3+}$-rich ferricrete units (Figure 2) existing within the Bahariya Formation that were initially thought to have formed in relation to change in sea level, although extra researches have recognized so many extra formation process (Salama et al., 2013 and Ciobotă et al. 2012). These extra processes involve contemporary sub-aerial corrosion (laterization) of Fe-bearing sedimentary phases (Catuneanu et al., 2006), the subsurface mobilization and re-precipitation of iron through groundwater mobilization (Tanner \& Khalifa 2010), and iron mineralization through bacterial mediation (Ciobotă et al., 2012). Fe oxides like amorphous Fe (III) oxide as Fe (OH) 3 , goethite $(\mathrm{FeOOH})$, akaganetite $(-\mathrm{FeOOH})$, maghemite $\left(\mathrm{Fe}_{2} \mathrm{O}_{3}\right)$ and magnetite $\left(\mathrm{Fe}_{3} \mathrm{O}_{4}\right)$ are the most dominant metallic oxides in the soils of Bahariya (Bae and Lee 2013). They are a significant problem in soil chemistry and plant nutritional importance, but their low solubility is the primary cause of Fe deficiency (Afia, 2004). To predict the availability of iron in soil, two primary parameters must be regarded: solubility and dissolution rate. Reduction of iron (III) oxides has a significant impact on the geochemistry of anaerobic soils and sediments through immediate microbial mediated mechanism (El-Aref et al., 2005). Amorphous iron (III) oxide is considered to be the predominant form of Fe (III) decreased in sediment environments, because very small amount of iron 
Citation: Sahar Mohamed Ismail; Sherine Shehata Marid and Doaa Taha Eissa Monitoring and Remediation of Environmental Aspects of Fe-rich Soils of Bahariya Oases and their Effects on peanut Quality Australian Journal of Basic and Applied Sciences, 13(9): 66-91. DOI: 10.22587/ajbas.2019.13.9.7

in crystalline iron (III) oxides form (e.g., goethite, hematite) has appeared to be accessible for reduction by Fe(III)-reducing organisms (Roden, 1996). The contaminated soils with heavy metals require unique soil-management procedures to restrict the solubility of the heavy metal. Heavy metal-contaminated soil remediation techniques provide physical and chemical remediation, phytoremediation, and agroecological methods (Chen et al., 2000). For chemical remediation, metal-stabilizing amendments are used to reduce their solubility, leaching, and bioavailability through different mechanisms including adsorption onto mineral surfaces, formation of stable complexes with organic legends, surface precipitation, and ion exchange (Kumpiene et al., 2008). The general goal of in situ amendment techniques is to isolate and stabilize Fe-contaminant in soils or sediments in order to decrease its capacity to partition into water or biota, and thus it's potentiality for transportation and pollution (Guo et al., 2006). The widely used immobilizers include Ca salts such as gypsum, dolomite, and phosphates and incorporation of certain non-toxic organic materials into polluted soils to reduce solubility of heavy metals in soils through precipitation, adsorption, or complexion (Hussain 2000). Phosphogypsum (PG) is consisted primarily of $\mathrm{CaSO}_{4}$, and includes impurities such as $\mathrm{Al}, \mathrm{P}, \mathrm{F}, \mathrm{Si}, \mathrm{Fe}$ and $\mathrm{Mg}$ as well as many of trace elements and has an acidic finely material that contains more than 90\% gypsum (Rutherford et al., 1994). PG is a low-cost source of $\mathrm{Ca}^{2+}$ which can be used as a soil amendment. As shown by Basta et al. (2005), the amendments which have functional groups like amino, hydroxyl and carbonyl groups were efficient in immobilizing heavy metals refer to their abilities to bind or complex metal. Sequestration mechanisms connected with mineral-based soil amendments fall into two wide classifications, surface adsorption and structural integration, each of which may have many molecular-scale variants. Both mechanisms can happen and change with time in complicated mixtures of amendments and soil (Guo et al., 2006). Metal cations tend to create strongly bound, inner-sphere surface complexes with soil minerals such that desorption is removed under typical soil conditions as long as $\mathrm{pH}$ stays high (Athmer et al., 2007). Although adsorption can be an efficient metal contaminant immobilization mechanisms that may undergo changes in speciation but does not degrade, there is an inherent risk that future changes in $\mathrm{pH}, \mathrm{Eh}$, ionic strength, or solution composition may change surface complex equilibria and desorb contaminants (Dragun, 1993). Some amendments react with soil water and minerals to change the composition, $\mathrm{pH}$, or Eh of the system, resulting in dissolution of solids and precipitation of new phases that can structurally integrate the contaminants (Dragun, 1993). Humic substances and semiquinone moieties mitigate the need for direct microbe-mineral surface interactions, raising the rates of $\mathrm{Fe}$ (III) reduction levels are naturally occurring and also anthropogenic derivatives can impact biogeochemistry through their ability to act as electron shuttles for extracellular redox processes such as Fe (III) decrease (Williamson et al., 2013). Based on the above, it is clear that there is a problem in the soil of Baharyia Oasis, namely colouring of the fruits of some crops with red colour (like potatoes and peanuts) especially the fruits that grow under the soil resulting loss of their marketing and export value. There are thousands of feddens cultivated with peanuts in soils of Baharyia Oases for export purpose accompanied by red pigment resulting in significant financial losses in export process, consequently, affecting on the national income. The aim of this study is i) a quantitative and qualitative monitoring of soil iron minerals and their chemical forms in Bahariya Oases, ii) to evaluate the effect of inorganic (gypsum, sulphur and phosphogypsum) and organic (biochar, k-humate and sugar industry waste) amendments on reduce of the Fe (III)-effects on peanut pods color and iii) effect of inorganic and organic soil amendments on soil chemical properties with selection the best of them.

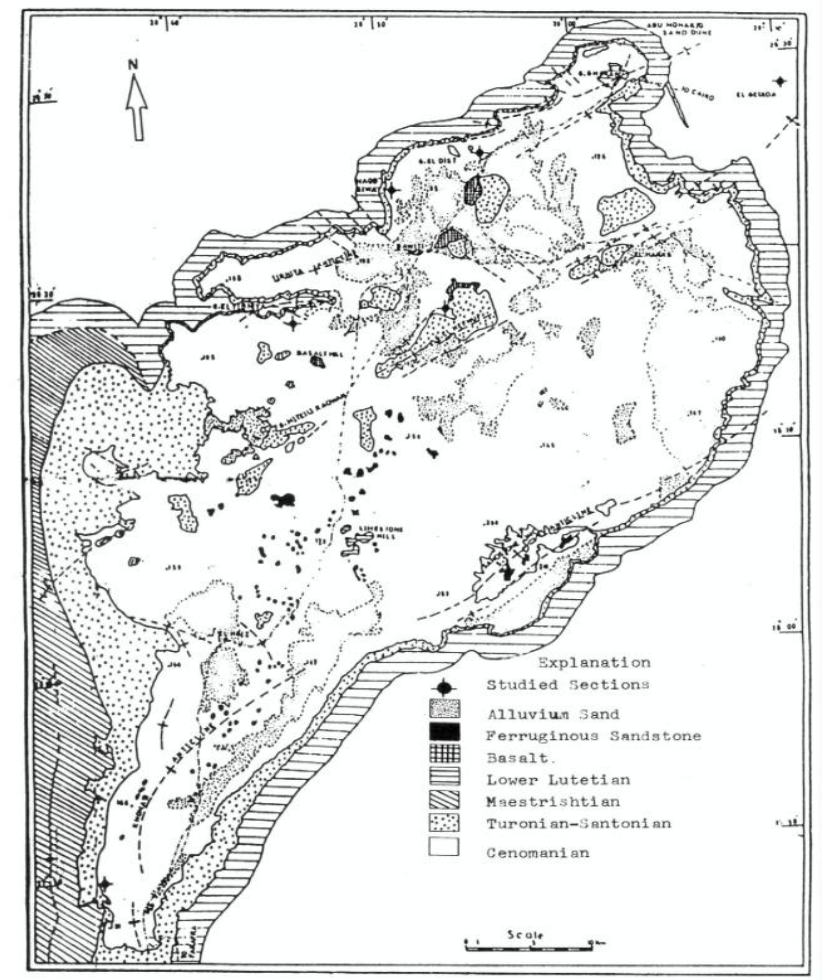

Fig.1 Simplified geologic map of Bahareia Oases according to Ministry of Agriculture and Land Reclamation. 
Citation: Sahar Mohamed Ismail; Sherine Shehata Marid and Doaa Taha Eissa Monitoring and Remediation of Environmental Aspects of Fe-rich Soils of Bahariya Oases and their Effects on peanut Quality Australian Journal of Basic and Applied Sciences, 13(9): 66-91. DOI: 10.22587/ajbas.2019.13.9.7

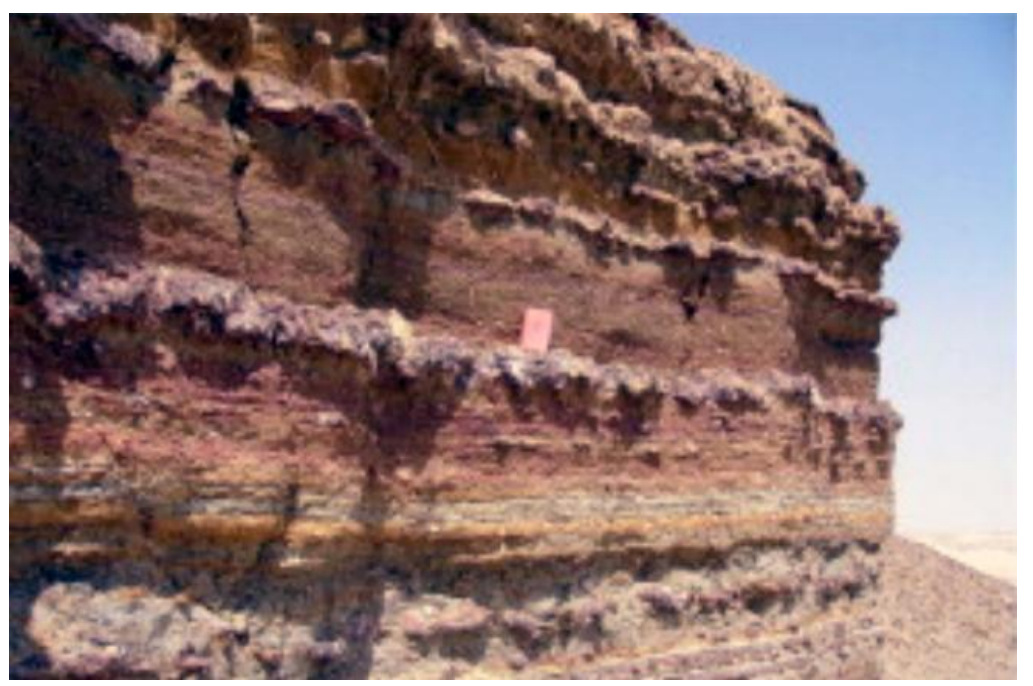

Fig. 2. A sequence of finely interbedded claystones, mudstones, and ferruginous sandstones at Gebel El- Dist in the Bahariya Oasis (Tanner \& Khalifa, 2010).

\section{MATERIALS AND METHODS}

\section{Location of the experiment and its layout}

A field experiment was carried out on the farm of Gannet El-Reda Company located in the northwestern part of Bahariya Oases (Figs. 3a and b) which lies at 365 kilometers South-West of Giza Governorate, Egypt (latitude of $28^{\circ} 0^{\prime}$ and $28^{\circ} 30^{\prime} \mathrm{N}$ and longitude of $28^{\circ} 40^{\prime}$ and $29^{\circ} 10^{\prime}$ E) during the summer season of June 2016 in a sandy red soil. Some physical and chemical properties of the studied soil and the water used for its irrigation were before planting are given in Table 1. Six treatments were applied as follows: Main plots were assigned to the organic and inorganic amendment treatments, i.e. gypsum (obtained from the soils improvement Agency of the Ministry of Agriculture), phosphogypsum (by-product of phosphoric acid industry, at AbuZaable district in Khalubia governorate), elemental sulphur powder (obtained from the soils improvement Agency of the Ministry of Agriculture), biochar (obtained from rice husk residues which were first dried in air and then cut into small pieces less than 4-5 $\mathrm{cm}$; thereafter, inserted into a ceramic vessel of $400 \mathrm{~cm}^{3}$ capacity that is used in a commercial electric furnace "SOMO-01 Isuzu, Japan" and charred for $10 \mathrm{~h}$ at different temperatures from 400 to $800^{\circ} \mathrm{C}$ at a heating rate of $10^{\circ} \mathrm{C} \min ^{-1}$ ), potassium humate (commercially available potassium humate, and designated as CHS) and sugar industry waste, SIW (obtained from sugar refining factory of sugar beet in Salah El-Abd village, El-Bostan region, El-Beheira Governorate, Egypt) as well as control. Subplots were presented as amendment application levels, which were 400, 500 and $600 \mathrm{~kg} \mathrm{fed}^{-1}$ for gypsum; 400,500 and $600 \mathrm{~kg}$ fed ${ }^{-1}$ for phosphogypsum; 100, 150 and $200 \mathrm{~kg} \mathrm{fed}^{-1}$ for sulphur; 1, 2 and 3 ton fed $\mathrm{f}^{-1}$ for biochar; 50,100 and $150 \mathrm{~kg}^{-1}$ fed potassium

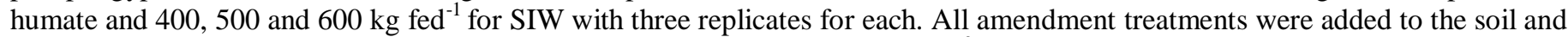
mixed thoroughly with the upper $25 \mathrm{~cm}$ layer. The area of each plot was $100 \mathrm{~m}^{2}$; hence; the total area of the field experiment was $5500 \mathrm{~m}^{2}$. Plants row spacing was $0.75 \mathrm{~m}$, and the distance between each plant was $0.25 \mathrm{~m}$. The used experimental design was complete randomized plots. Peanut grains (Arachis hypogaea L.; Var., Virginia) were cultivated (on 6 June 2016), as shown in Fig. 4a, the recommended doses of fertilizers were added according to leaflet Agriculture Research Centre under this province conditions $\left(200 \mathrm{~kg} \mathrm{~N}, 40 \mathrm{Kg} \mathrm{P}\right.$ and $\left.80 \mathrm{~kg} \mathrm{~K} \mathrm{fed}^{-1}\right)$. Combined fertilizer was added in the form $(20 \mathrm{~N}-10 \mathrm{P}-5 \mathrm{~K})$ from the $2^{\text {nd }}$ week until the $7^{\text {th }}$ week of the plant growth period, whereas, another combined fertilizer in the form (10N-3P-36K) was applied from the $8^{\text {th }}$ week until the end of fertilization programme. After 180 days from cultivation, the peanut was harvested (Fig. 4b).

\section{Preliminary Spectral Analyses for soil and amendments before experiment carrying out:}

The soil samples were collected at the depth of $0-30 \mathrm{~cm}$ for mineralogy determination. X-ray diffraction using Philips Xray diffractometer (Philips 1710) and visible/near-infrared (VNIR) reflectance and thermal infrared (TIR) emission spectra were used for defining spectrally the important minerals (Figs.5 and 6). VNIR spectra $(0.35-2.50 \mu \mathrm{m})$ were obtained from the Zewail City of Science, Imaging and Microscopy Center, Institute of Nanotechnology using an ASD FieldSpec4 spectroradiometer instrument under controlled illumination with an emergence angle of $30^{\circ}$ and an illumination angle of $0^{\circ}$. Using $\mathrm{x}-\mathrm{ray}$ fluorescence spectrometer for soil mineral composition was performed to determine the major and some of the minor components as shown in Table (1). Fourier transform infrared (FTIR) spectra of the used amendments i.e. gypsum (Fig. 7), phosphogypsum (Fig. 8), sulphur (Fig. 9), biochar (Fig. 10), potassium humate (Fig. 11) and sugar industry waste (Fig. 12) was analyzed on a Varian 670-IR (Agilent Technologies Inc., CA) using the pellet method. The broad-band function was used (Guo and Chen, 2014 and $\mathrm{Wu}$ et al., 2012). Surface morphology of the rice husk biochar sample was observed under the Jeol JSM-6400 electron scanning microscope and The Brunauer, Emmett and Teller (BET) surface area for biochar was detected. 
Citation: Sahar Mohamed Ismail; Sherine Shehata Marid and Doaa Taha Eissa Monitoring and Remediation of Environmental Aspects of Fe-rich Soils of Bahariya Oases and their Effects on peanut Quality Australian Journal of Basic and Applied Sciences, 13(9): 66-91. DOI: 10.22587/ajbas.2019.13.9.7

\section{Climatic conditions and irrigation system}

Baharyia Oases has a desert climate and the average summer temperature is $40^{\circ} \mathrm{C}$. The source of irrigation is well water and the irrigation system is a pivot.

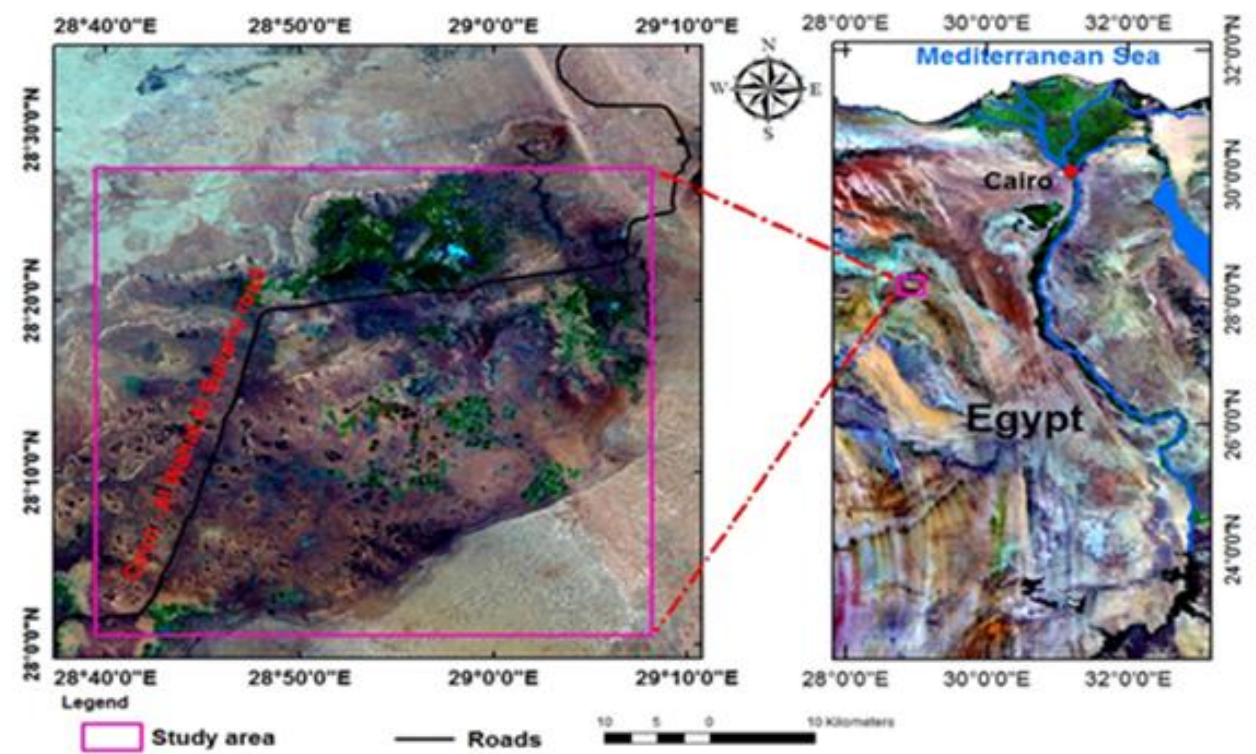

Fig.3a. Location of the study area of Al-Bahariya Oases-Egypt

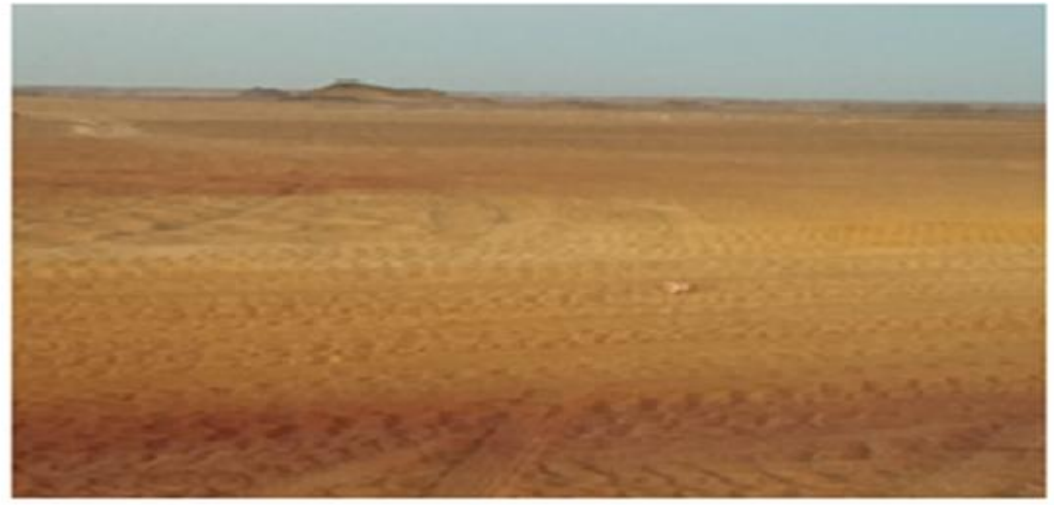

Fig.3b. Original the studied soil before the planting ( Al-Baharyia Oases)

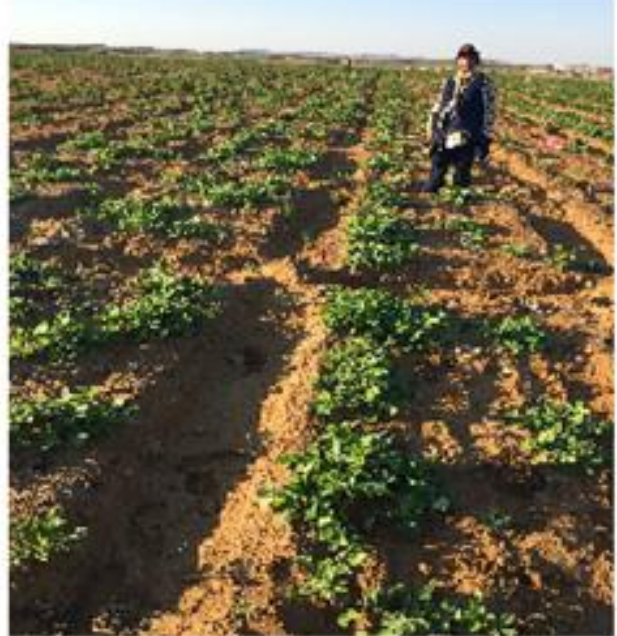

Fig. 4a. Peanut experiment in Bahariya Oases

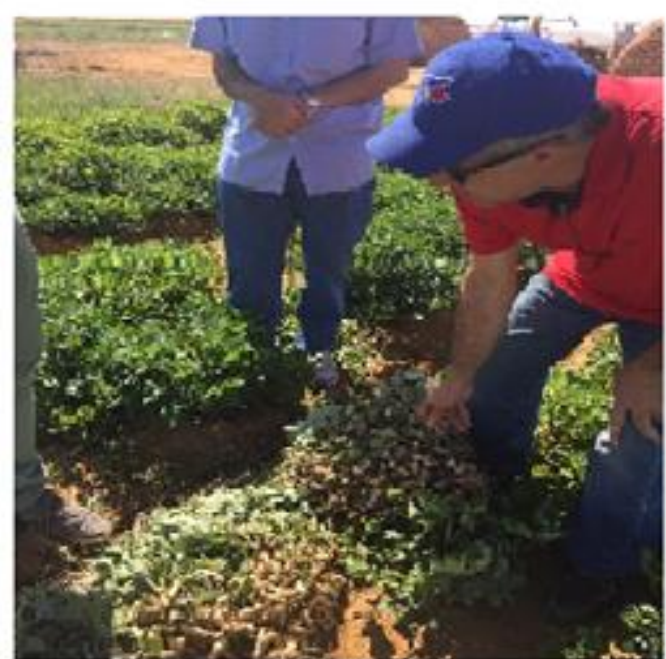

Fig. 4b. Harvest of peanuts in Bahariya Oases 
Citation: Sahar Mohamed Ismail; Sherine Shehata Marid and Doaa Taha Eissa Monitoring and Remediation of Environmental Aspects of Fe-rich Soils of Bahariya Oases and their Effects on peanut Quality Australian Journal of Basic and Applied Sciences, 13(9): 66-91. DOI: 10.22587/ajbas.2019.13.9.7

\section{Soil sampling and analysis after peanut harvest}

Soil samples were collected after peanut harvest at depths of $0-30 \mathrm{~cm}$ and $30-60 \mathrm{~cm}$. The collected samples were air dried, crushed, sieved through a $2 \mathrm{~mm}$ sieve and stored in plastic bags for chemical characteristics determination (Table 2). Soil particle size distribution was conducted using the pipette method as described by Bouyoucos (1962). Total calcium carbonate was determined gas- metrically using Calcimeter according to Mclean, (1982). Soil reaction ( $\mathrm{pH}$ ) was measured in saturated soil paste using combined electrode $\mathrm{pH}$ meter as mentioned by Mckeague, (1978). Total soluble salts were determined by measuring the electrical conductivity in the extract of saturated soil paste in $\mathrm{dS} \mathrm{m}^{-1}$ as explained by Richards (1954). Water-soluble cations (Ca ${ }^{2+}$, $\mathrm{Mg}^{2+}, \mathrm{Na}^{+}$and $\left.\mathrm{K}^{+}\right)$and anions $\left(\mathrm{CO}_{3}{ }^{2-}, \mathrm{HCO}_{3}{ }^{-}\right.$and $\left.\mathrm{Cl}^{-}\right)$were determined in the extract of saturated soil paste by the methods described by Richards (1954), whereas $\left(\mathrm{SO}_{4}{ }^{2-}\right.$ ) ions were calculated as the difference between total cations and anions. Soluble $\mathrm{Ca}^{2+}$ and $\mathrm{Mg}^{2+}$ were determined by titration with standard versenate solution. Soluble $\mathrm{Na}^{+}$and $\mathrm{K}^{+}$ions were determined by using a flame photometer. Soluble $\mathrm{CO}_{3}{ }^{2-}$ and $\mathrm{HCO}_{3}{ }^{-}$ions titration with standardized $\mathrm{H}_{2} \mathrm{SO}_{4}{ }^{2-}$ solution were assessed. Soluble $\mathrm{Cl}^{-}$ion titration with standardized silver nitrate solution was determined. Organic carbon was performed by the Walkley-Black wet combustion method (Nelson and Sommers, 1982), cation exchange capacity (CEC) was extracted by ammonium acetate according to Rhoades (1982). The ammonium bicarbonate diethylenetriaminepenta acetic acid (AB-DTPA) was used for extraction of Fe, $\mathrm{Mn}, \mathrm{Zn}, \mathrm{Cu}, \mathrm{Ni}$ and $\mathrm{Cd}$ as described by Soltanpour (1985). Thereafter, micronutrients in the extracts were measured using atomic absorption spectrophotometer (Perkin Elemer $100 \mathrm{~B}$ ). The used amendments were exposed to some chemical analyses as shown in Table 3 and Table 4.

Table (1): Chemical composition of the upper layer $(0-30 \mathrm{~cm})$ sample of the studied soil

\begin{tabular}{|c|c|c|c|}
\hline Component & Wt. \% & Component & Wt. \% \\
\hline $\mathrm{SiO}_{2}$ & 36.81 & $\mathrm{TiO}_{2}$ & 0.12 \\
$\mathrm{Al}_{2} \mathrm{O}_{3}$ & 0.94 & $\mathrm{SO}_{3}$ & 0.36 \\
$\mathrm{FeO}(\mathrm{Fe})$ & $44.10(34.30)$ & $\mathrm{P}_{2} \mathrm{O}_{5}$ & 0.18 \\
$\mathrm{MgO}$ & 0.14 & $\mathrm{MnO}_{2}$ & 0.21 \\
$\mathrm{CaO}$ & 0.59 & $\mathrm{ZnO}_{2}$ & 0.07 \\
$\mathrm{Na}_{2} \mathrm{O}_{3}$ & 3.70 & $\mathrm{BaO}$ & 0.70 \\
$\mathrm{~K}_{2} \mathrm{O}_{3}$ & 0.01 & $\mathrm{C}$ & 0.14 \\
$\mathrm{Cl}$ & 1.96 & & \\
Total & - & - & 9.90 \\
\hline
\end{tabular}

${ }^{\#}$ Ig: Igneous gases

\section{Plant sampling and analysis after the harvest}

Some morphological measurements of peanut plants, i.e. pods yield $\left(\mathrm{g} / 100 \mathrm{~m}^{2}\right)$, the weight of 100 pods $(\mathrm{g})$ were measured. Also, the appearance of the red pigment or not on the pods was followed up. Total nitrogen content in shoot and grains was determined by Kjeldahl method (Chapman and Pratt, 1978). Total phosphorus content in shoot and grains was determined calorimetrically using vanadate method as described by Page et al. (1982). Total potassium content in shoot and grains was determined by Flame photometer (Page et al., 1982). Total heavy metals $\mathrm{Fe}, \mathrm{Mn}, \mathrm{Zn}, \mathrm{Cu}, \mathrm{Ni}$ and $\mathrm{Cd}$ in the shoots and grains were measured by atomic absorption spectrometer (Page et al., 1982). Data were statistically analyzed using analysis of variance adopting a SAS software package (SAS Institute, 1996).

\section{RESULTS AND DISCUSSION}

\section{Preliminary Spectral Analyses Data of Soil Upper layer Samples and their chemical composition at the beginning of the trial}

According to the pattern of X-ray diffraction shown in (Fig. 5), the soil samples consisted primarily of iron minerals, goethite and tiny quantities of hematite and gangue minerals represented mainly by quartz, in addition to small quantities of halite and illite. These minerals are recognized according to their strong diffraction lines given in Fig. 5. Also, visible/near-infrared (VNIR) reflectance and thermal infrared (TIR) emission spectra of the Bahariya Oases soil samples indicated the dominance of crystalline Fe-oxides (hematite and goethite, Fig. 6a) at wavelengths less than $1.0 \mu \mathrm{m}$. TIR spectra $\left(2000-200 \mathrm{~cm}^{-1}\right)$ were obtained by thermal Emission Spectroscopy using a Nicolet Nexus 670 spectrometer according to the methods of Ruff et al. (1997) and unmixed using the non-negative least squares model according to Rogers and Aharonson (2008) as shown in Fig. 6b. Un-mixing of a ferruginous sandstone indicated $\sim 50 \%$ phyllosilicates (dominated by Fe-smectite), $\sim 11 \%$ carbonate, $\sim 11 \%$ quartz, and $\sim 10 \%$ Fe-oxides (combination of hematite and goethite), in agreement with x-ray diffraction spectrum (Fig. 5). These findings indicate that both VNIR and TIR analyses are precious additions to the study of Fe-oxide-bearing lithologies from the Bahariya Oases. The chemical analysis of the studied soil samples indicated that the iron oxide and silica are the primary components representing four-fifths $(80.91 \%)$ of the soil $\left(44.10 \% \mathrm{FeO}\right.$ and $\left.36.81 \% \mathrm{SiO}_{2}\right)$, which can be ascribed to the dominance of iron oxy-hydroxides and quartz. In this case the iron constituted $34.30 \%$ of the sample, while the other components were found in small quantities, in 
particular, chloride and sodium refer to the presence of halite, aluminium due to the presence of clay minerals, sulphur refer to the presence of very small percentage of pyrite, manganese due to the presence of small amount of Mn oxides and barium ascribed to the presence of small percentage of barite (Tables 1 and 2).

\section{Preliminary Spectral Analyses Data of Soil amendments and their chemical composition at the beginning of the trial 2.1. Soil inorganic amendments}

a. Gypsum

The FT-IR technique is a key tool for identifying some significant functional groups. The gypsum sample FTIR spectrum (Fig. 7) revealed the existence of typical calcium sulphate hydrate vibration bands, frequently referred to as gypsum $\left(\mathrm{CaSO}_{4} \cdot 2 \mathrm{H}_{2} \mathrm{O}\right)$, centred at 1109,669 , and $596 \mathrm{~cm}^{-1}$ besides the stretching and deformation vibrations of the $\mathrm{O}-\mathrm{H}$ water bond at $3525,3492,3401 \mathrm{~cm}^{-1}$ and at 1692 and $1627 \mathrm{~cm}^{-1}$, respectively.

Table (2): Some chemical and physical characteristics of the studied soil and the water used for its irrigation (Well source)

\begin{tabular}{|c|c|c|}
\hline Character & Soil & water \\
\hline \multicolumn{3}{|l|}{ Particle size distribution $\%$} \\
\hline Sand & 84.55 & \\
\hline Silt & 9.76 & \\
\hline Clay & 5.69 & \\
\hline Textural class & Sandy & \\
\hline Field capacity (\%) & 10.70 & \\
\hline \multicolumn{3}{|l|}{ Soil chemical properties } \\
\hline Calcium carbonate $\left(\mathrm{g} \mathrm{kg}^{-1}\right)$ & 850 & \\
\hline $\mathrm{OC}, \mathrm{g} \mathrm{kg}^{-1}$ & 10.20 & \\
\hline $\mathrm{OM}, \mathrm{g} \mathrm{kg}^{-1}$ & 17.60 & \\
\hline $\mathrm{CEC}, \mathrm{cmol} \mathrm{kg}^{-1}$ & 45.00 & \\
\hline $\mathrm{pH}$ (soil paste) & 7.84 & 7.20 \\
\hline $\mathrm{EC}_{\mathrm{e}}, \mathrm{dS} \mathrm{m}^{-1}$ & 6.18 & 6.52 \\
\hline \multicolumn{3}{|l|}{ Soluble ions, $\mathrm{mmol}_{\mathrm{c}} \mathrm{L}^{-1}$} \\
\hline $\mathrm{Ca}^{2+}$ & 13.75 & 12.46 \\
\hline $\mathrm{Mg}^{2+}$ & 11.25 & 10.73 \\
\hline $\mathrm{Na}^{+}$ & 33.68 & 38.88 \\
\hline $\mathrm{K}^{+}$ & 2.44 & 3.05 \\
\hline $\mathrm{HCO}_{3}^{-}$ & 10.65 & 7.11 \\
\hline $\mathrm{Cl}^{-}$ & 39.21 & 42.00 \\
\hline $\mathrm{SO}_{4}{ }^{2-}$ & 11.30 & 16.06 \\
\hline${ }^{*}$ SAR & 3.53 & 3.40 \\
\hline${ }^{* * *}$ ESP, $\%$ & 5.58 & - \\
\hline \multicolumn{3}{|c|}{ Total content of microelements, $\mathrm{mg} \mathrm{kg}^{-1}$} \\
\hline $\mathrm{Fe}$ & 42000 & 966 \\
\hline $\mathrm{Mn}$ & 1100 & 86 \\
\hline $\mathrm{Zn}$ & 195 & 12 \\
\hline $\mathrm{Cu}$ & 186 & 6.5 \\
\hline \multicolumn{3}{|c|}{ Chemically available heavy metals, $\mathrm{mg} \mathrm{kg}^{-1}$} \\
\hline $\mathrm{Fe}$ & 14.70 & \\
\hline $\mathrm{Mn}$ & 41.60 & \\
\hline $\mathrm{Zn}$ & 18.80 & \\
\hline $\mathrm{Cu}$ & 8.06 & \\
\hline
\end{tabular}

*SAR: Sodium Adsorption Ratio: $\left.\mathrm{Na}^{+} / \sqrt{(\mathrm{Ca}}+\mathrm{Mg}\right) / 2 \quad$ *ESP: calculated by equation $1.95+1.03$ SAR (Mohsen, 2009).

Table (3): Some characteristics of the used inorganic amendments

\begin{tabular}{|c|c|c|c|}
\hline Character & Gypsum & Character & Phosphogypsum \\
\hline $\mathrm{pH}(1: 2.5)$ & 4.22 & $\mathrm{P}_{2} \mathrm{O}_{5}, \%$ & $0.3-1.3$ \\
\hline ECe, $\mathrm{dS} \mathrm{m}^{-1}(1: 2.5)^{\#}$ & 2.62 & $\mathrm{pH}(1: 2.5)^{\#}$ & 4.46 \\
\hline Organic carbon, $\%$ & n.d. & Calcium sulphate, $\mathrm{g} \mathrm{kg}^{-1}$ & 900 \\
\hline Organic matter, \% & n.d. & Calcium oxides, $\%$ & $28-36$ \\
\hline \multicolumn{2}{|c|}{$\mathrm{C} / \mathrm{N}$ ratio } & Silicon, & 11.68 \\
\hline & & Aluminium, $\%$ & 0.88 \\
\hline \multicolumn{2}{|c|}{ Total content of macronutrients, \% } & Iron, $\%$ & 0.32 \\
\hline $\mathrm{Ca}$ & 20.70 & $\mathrm{SiO}_{2}, \%$ & $1.2-2.6$ \\
\hline $\mathrm{Mg}$ & 3.75 & $\mathrm{Al}_{2} \mathrm{O}_{3}, \%$ & $0.1-0.2$ \\
\hline $\mathrm{N}$ & 0.05 & $\mathrm{Na}_{2} \mathrm{O}+\mathrm{K}_{2} \mathrm{O}, \%$ & 0.17 \\
\hline $\mathrm{P}$ & 0.02 & $\mathrm{Fe}_{2} \mathrm{O}_{3}, \%$ & $0.1-0.3$ \\
\hline K & 0.15 & $\mathrm{~F}, \%$ & 0.24 \\
\hline \multicolumn{2}{|c|}{ Total content of heavy metals, $\mathrm{mg} \mathrm{kg}^{-1}$} & $\mathrm{MgO}, \%$ & 0.21 \\
\hline $\mathrm{Fe}$ & 81.00 & $\mathrm{SO}_{3}, \%$ & $52-61$ \\
\hline Mn & 19.00 & Specific surface area, $\mathrm{cm}^{2} \mathrm{~g}^{-1}$ & 4670 \\
\hline $\mathrm{Zn}$ & 5.20 & Specific gravity & 2.96 \\
\hline $\mathrm{Cu}$ & 2.80 & & \\
\hline
\end{tabular}


Citation: Sahar Mohamed Ismail; Sherine Shehata Marid and Doaa Taha Eissa Monitoring and Remediation of Environmental Aspects of Fe-rich Soils of Bahariya Oases and their Effects on peanut Quality Australian Journal of Basic and Applied Sciences, 13(9): 66-91. DOI: 10.22587/ajbas.2019.13.9.7

\begin{tabular}{|c|c|c|c|}
\hline $\mathrm{Ni}$ & 1.12 & Character & Sulpher \\
\hline $\mathrm{Cd}$ & 0.49 & Sulfur element $(\mathrm{S})$ & $95 \%$ \\
\hline \multicolumn{2}{|c|}{ Chemically available heavy metals, $\mathrm{mg} \mathrm{kg}^{-1}$} & $\mathrm{pH}(1: 1)$ & 3.70 \\
\hline $\mathrm{Fe}$ & 2.50 & $\mathrm{EC}_{\mathrm{e}}(1: 1)$ & 0.44 \\
\hline Mn & 1.70 & $\mathrm{Ca}^{2+}, \mathrm{mg} \mathrm{kg}^{-1}$ & 64 \\
\hline $\mathrm{Zn}$ & 1.30 & Gypsum, \% & 0.0036 \\
\hline $\mathrm{Cu}$ & 1.27 & Carbon, $\%$ & 0.12 \\
\hline $\mathrm{Ni}$ & 0.57 & Clay, $\%$ & 1.50 \\
\hline \multirow[t]{2}{*}{$\mathrm{Cd}$} & 0.12 & Hydrocarbons, \% & 0.06 \\
\hline & & Diameter, mesh & 325 \\
\hline
\end{tabular}

n.d. $=$ Not detected $\quad(1: 2.5)^{\#}=$ Amendment: water ratio

Table (4): Some characteristics of the used organic amendments

\begin{tabular}{|c|c|c|c|}
\hline Character & $\begin{array}{l}\text { Biochar (Rice husk) } \\
\text { at } 500{ }^{\circ} \mathrm{C}\end{array}$ & Character & Sugar industry waste \\
\hline biochar yield, \% & 8.60 & $\mathrm{pH}(1: 5)$ & 8.39 \\
\hline volatile content, $\%$ & 22.00 & $\mathrm{EC}(1: 5), \mathrm{dSm}^{-1}$ & 0.69 \\
\hline $\mathrm{pH}\left(\mathrm{H}_{2} \mathrm{O}\right)$ & 7.40 & $\mathrm{CaCO}_{3}, \%$ & 44.96 \\
\hline $\mathrm{CEC}\left(\mathrm{cmol}_{\mathrm{c}} \mathrm{kg}^{-1}\right)$ & 32.34 & & \\
\hline Exchangeable K (mg/100 biochar) & 1.92 & Ashes, $\%$ & 75.25 \\
\hline Phosphorus, $\mathrm{P}\left(\mathrm{mg} \mathrm{kg}^{-1}\right)$ & 0.93 & & \\
\hline BET surface area, $\mathrm{m}^{2} \mathrm{~g}^{-1}$ & 23.20 & Total nitrogen, $\%$ & 0.15 \\
\hline Organic-C $\left(\mathrm{g} \mathrm{kg}^{-1}\right)$ & 319.20 & $\mathrm{C} / \mathrm{N}$ ratio & 5.60 \\
\hline $\mathrm{C}(\%)$ & 45.90 & & \\
\hline $\mathrm{H}(\%)$ & 2.50 & Particle size $(\mu \mathrm{m})$ & 5.07 \\
\hline $\mathrm{N}(\%)$ & 0.14 & Mineral oxide, $\mathrm{mg} \mathrm{kg}^{-1}$ & \\
\hline $\mathrm{O}(\%)$ & 16.32 & $\mathrm{CaO}, \%$ & 46 \\
\hline $\mathrm{O} / \mathrm{C}$ ratio & 3.55 & $\mathrm{MgO}, \%$ & 1.98 \\
\hline $\mathrm{C} / \mathrm{N}$ ratio & 32.78 & $\mathrm{SiO}_{2}, \%$ & 1.34 \\
\hline \multirow[t]{2}{*}{$\mathrm{H} / \mathrm{C}$ ratio } & 0.54 & $\mathrm{Al}_{2} \mathrm{O}_{3}, \%$ & 0.40 \\
\hline & & $\mathrm{Fe}_{2} \mathrm{O}_{3}, \%$ & 0.28 \\
\hline Charcter & K-humate & $\mathrm{Na}_{2} \mathrm{O}, \%$ & 0.22 \\
\hline $\mathrm{pH}(1: 1)$ & 8.00 & $\mathrm{~K}_{2} \mathrm{O}, \%$ & 0.11 \\
\hline $\mathrm{EC}, \mathrm{dSm}^{-1}$ & 0.04 & $\mathrm{P}_{2} \mathrm{O}_{5}, \%$ & 0.30 \\
\hline Organic matter, g kg-1 & 215 & & \\
\hline \multicolumn{4}{|l|}{ Total nutrients } \\
\hline Nitrogen, $\%$ & 3.71 & & \\
\hline Potassium, $\%$ & 6.25 & & \\
\hline Calcium, \% & 0.80 & & \\
\hline Magnesium, $\%$ & 0.024 & & \\
\hline Sulphur, \% & 0.55 & & \\
\hline Zinc, $\mathrm{mg} \mathrm{g}^{-1}$ & 42 & & \\
\hline Copper, $\mathrm{mg} \mathrm{g}^{-1}$ & 20 & & \\
\hline Iron, $\mathrm{mg} \mathrm{g}^{-1}$ & 24 & & \\
\hline Manganese, $\mathrm{mg} \mathrm{g}^{-1}$ & 13 & & \\
\hline
\end{tabular}

\section{b. Phosphogypsum}

Using FT-IR spectroscopy, the functional groups of phosphogypsum samples were defined and their spectra are shown in Figure (8). The infrared spectra of phosphogypsum studied from terraces I-IV were almost similar. Hydroxyl functional groups were assigned by the strong broad band that specified around wavenumbers 3395, 1681 and $1618 \mathrm{~cm}^{-1}$. The two distinct peaks at wavenumbers about $1681,1619 \mathrm{~cm}^{-1}$, and strongly doubled peak at wavenumber $3395 \mathrm{~cm}^{-1}$ of the studied samples indicate that the -OH functional groups could be found in the hydrated form of phosphogypsum owing to bonded crystalline water (Balintova, 2016). Bands at wavenumbers 1681 and $1619 \mathrm{~cm}^{-1}$ in the phosphogypsum samples are refer to the existence of two kinds of water molecules in gypsum. The tetrahedral sulphate anion displays nine ordinary modes (Farmer, 1974) with a symmetric stretch of $v 1$ $\left(1000 \mathrm{~cm}^{-1}\right)$, a doubly degenerate symmetric bending of $\vee 2\left(500-400 \mathrm{~cm}^{-1}\right)$, a triply degenerate asymmetric stretching of $\vee 3$ $\left(1250-1050 \mathrm{~cm}^{-1}\right)$, and a triply degenerate bending of $v 4\left(700-500 \mathrm{~cm}^{-1}\right)$. Sulphate functional groups could be referred to the strong wide band at wavenumber $1090 \mathrm{~cm}^{-1}$ and deformations at wavenumbers 666, 596, and $457 \mathrm{~cm}^{-1}$. The phosphogypsum FTIR spectra were comparable whatever the sample composition might be. The distinctive bands for phosphate groups are present at wavenumbers $1120-1020,960,600-550$, and $460 \mathrm{~cm}^{-1}$ (Raynaud, 2002). These standard absorption deformations of the hydrogen phosphate ions were overlaid on those of the sulphate ion. However, it could be deduced from the acquired spectra that hydrogen phosphate has an absorption deformation area represented at wavenumber $1250-1050 \mathrm{~cm}^{-1}$ which is followed by stretching to a width of the otherwise typical sharp asymmetric stretching of sulphate ions. The silicon is defined by the existence of $\mathrm{SiO}_{4}$ tetrahedral units. The standard IR spectrum of silica reveals the existence of the two transverse optical modes of the $\mathrm{Si}-\mathrm{O}-\mathrm{Si}$ groups: the bending $\mathrm{Si}-\mathrm{O}$ vibration specified around $800 \mathrm{~cm}^{-1}$ (Junakova and Balintova, 2013) and the asymmetric Si-O stretching mode situated in the range $1300-1000 \mathrm{~cm}^{-1}$ (Serra, 2003). In this case, the asymmetric $\mathrm{Si}-\mathrm{O}$ stretching mode is covered by the functional groups of sulphate and phosphate with higher concentrations. 


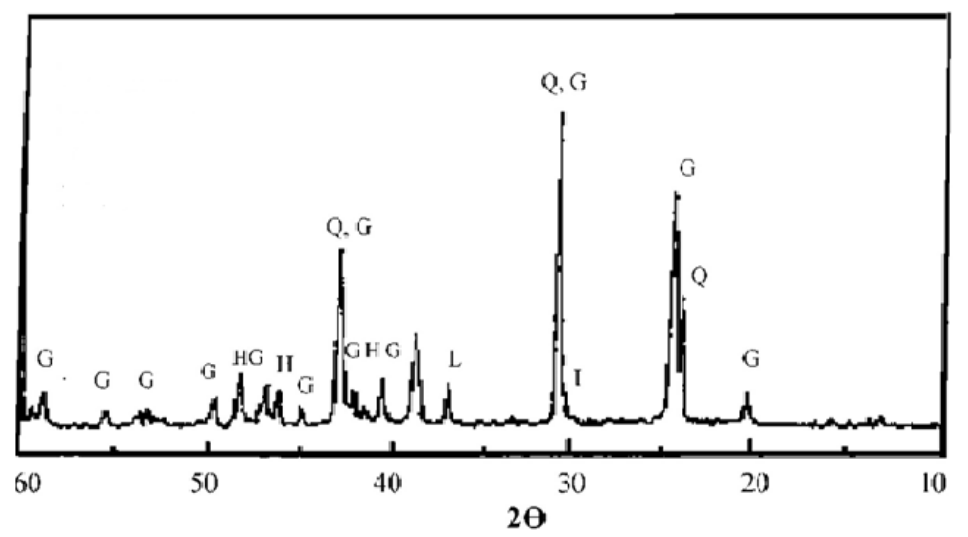

Fig. (5): X-ray diffraction pattern of the studied soil of Bahariya Oases, (G): goethite; II: hematite; Q: quartz; L: halite; I: illite.
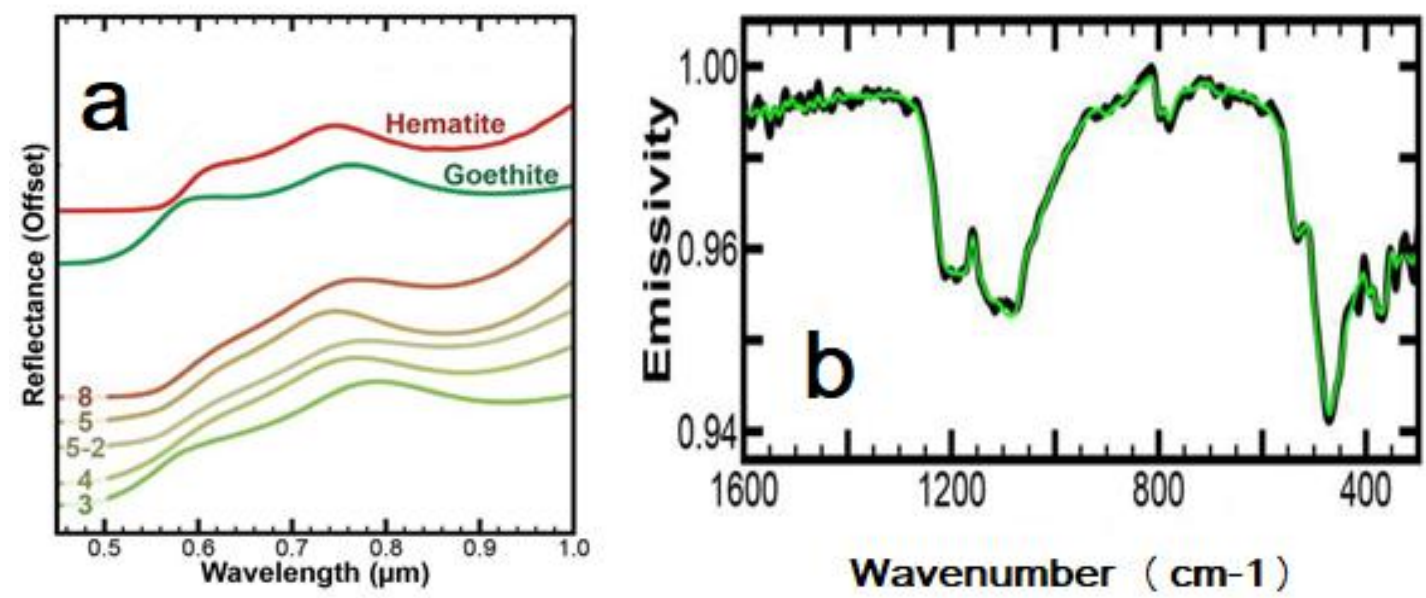

Fig. (6): (a) Speciation of iron oxides of the samples from the experimental soil by VNIR spectra with pure hematite and goethite for comparison. The color of the Bahariya spectra reflect the relative spectral similarity to hematite (red) and goethite (green). Numbers next to each Bahariya spectrum correspond to sample numbers. (b) A TIR spectrum of a ferruginous sandstone from the Bahariya Formation (black) with the result of a linear un-mixing analysis overlain (green).

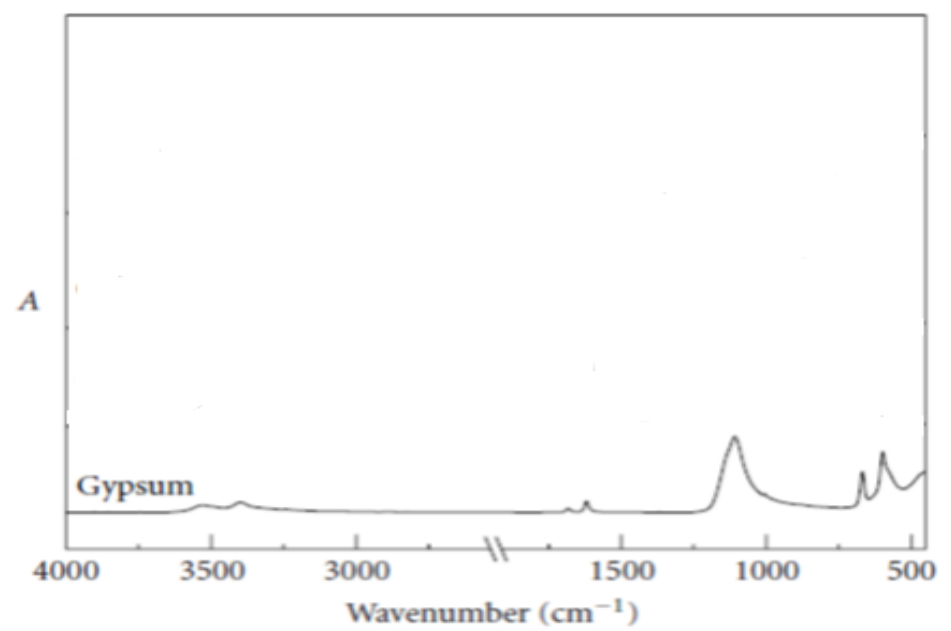

Fig. (7). Fourier transform infrared (FTIR) spectrum of gypsum in the range of wave length 4000 to $500 \mathrm{~cm}^{-1}, A$ is absorbance. 


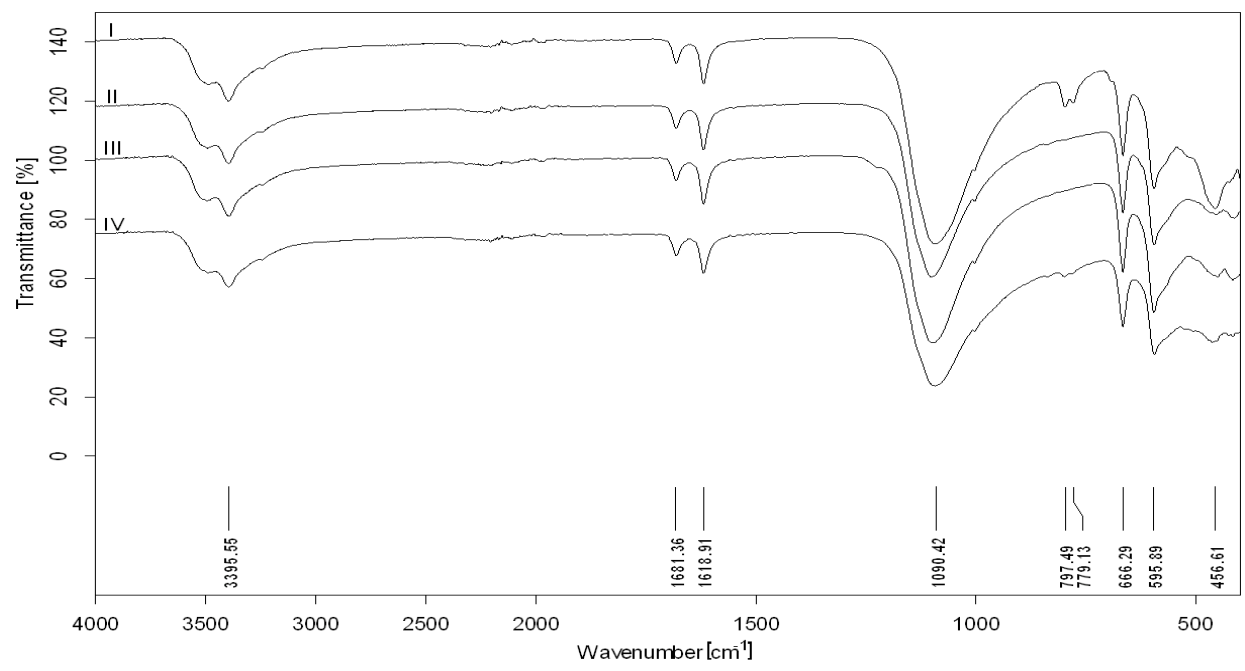

Fig. (8). Fourier transform infrared (FTIR) spectra of phosphogypsum in the range of wave length 4000 to $500 \mathrm{~cm}^{-1}$.

\section{c. Sulphur}

Figure (9) demonstrates the FT-IR spectrum of original sulfur particles and indicates that there is a symmetric $\mathrm{O}=\mathrm{S}=\mathrm{O}$ stretching mode found in the range of wavenumbers $1100-1400 \mathrm{~cm}^{-1}$ (Serra, 2003), while, the distinctive bands are found in the range of wavenumbers $600-1000 \mathrm{~cm}^{-1}$ for some aromatic, alkyne and alkene groups.

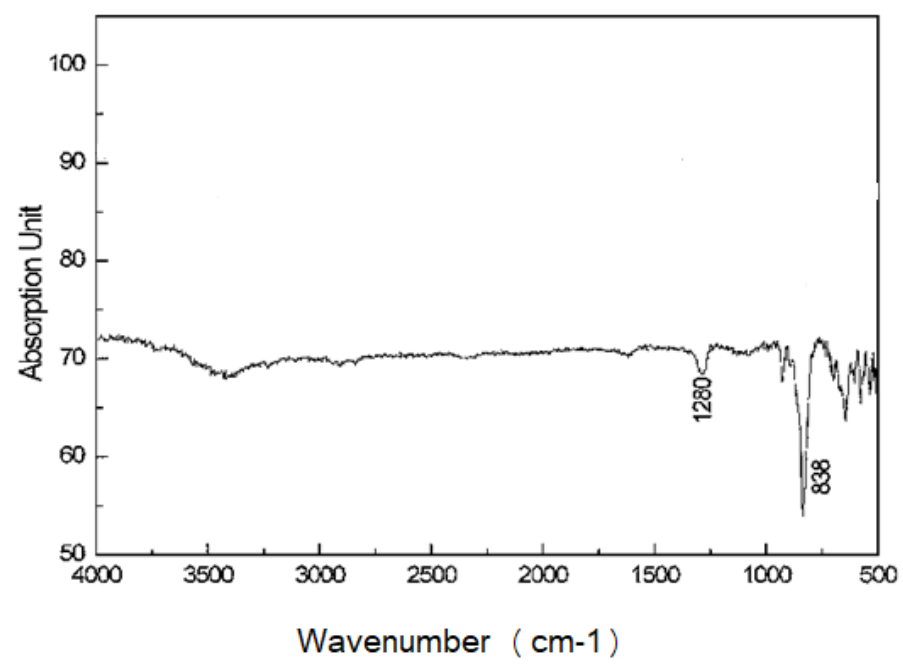

Fig. (9). Fourier transforms infrared (FTIR) spectrum of original sulfur powder in the range of wavelength 4000 to $500 \mathrm{~cm}^{-1}$.

\subsection{Soil organic amendments \\ a. Biochar}

As shown in Figure (10), the nature of the raw material was expressed by the existence of bands around 460, 800, and 1040-1100 $\mathrm{cm}^{-1}$, which were defined as $\mathrm{SiO}_{2}$. In-plant physiology science, silica is considered as the most main component for plant phytoliths, because it protects the plant carbon from degradation (Parr, 2006). Actually, $\mathrm{SiO}_{2}$ is a significant component in the chemical structure of rice material. In the rice husk $(\mathrm{RH})$ biochar which was assigned to the aromatic compounds during the biochar production, it was observed a shoulder around $1600 \mathrm{~cm}^{-1}$. Guo and Chen (2014) suggested a novel silicon-carbon model that could provide a new viewpoint for the assessing of the biochar stability. Some scientists (Qian et al., 2016) noted that the organic and inorganic functional groups were dominated by $-\mathrm{OH}\left(3405 \mathrm{~cm}^{-1}\right)$, ester $\mathrm{C}=\mathrm{O}\left(1732 \mathrm{~cm}^{-1}\right.$ and $\left.1162 \mathrm{~cm}^{-1}\right)$, aromatic $\mathrm{C}=\mathrm{C}\left(1651 \mathrm{~cm}^{-1}\right), \mathrm{C}-\mathrm{O}\left(1200-1060 \mathrm{~cm}^{-1}\right)$ at low temperatures, while the organic functional groups were either reduced or eliminated as the temperature increased. With pyrolysis temperature, the elemental content increased as more organic material volatilized proportionally, while most of the minerals stayed in the biochar as shown in Table 4 (Buss et al., 2016). The content of components such as $\mathrm{Ca}, \mathrm{K}$ and phosphorus $(\mathrm{P})$, surface area, $\mathrm{pH}$, and biochar $\mathrm{C} / \mathrm{N}$ and $\mathrm{C} / \mathrm{O}$ ratios improved with higher pyrolysis temperatures and these were in agreement with Saifullah et al. (2018). Overall it can be said that the biochar produced at comparatively elevated pyrolysis temperatures is efficient in the sorption of organic contaminants by enhancing the surface area, micro-porosity and hydrophobicity. In contrast, the biochar produced by low-temperature pyrolysis is accessible to remove inorganic/organic pollutants, which depends on the functional groups containing oxygen, electrostatic attraction, and precipitation (Ahmad et al., 2014). Méndez et al. (2014) deduced that biochar produced at $500{ }^{\circ} \mathrm{C}$ could decrease the amount of mobile, leached 
Citation: Sahar Mohamed Ismail; Sherine Shehata Marid and Doaa Taha Eissa Monitoring and Remediation of Environmental Aspects of Fe-rich Soils of Bahariya Oases and their Effects on peanut Quality Australian Journal of Basic and Applied Sciences, 13(9): 66-91. DOI: 10.22587/ajbas.2019.13.9.7

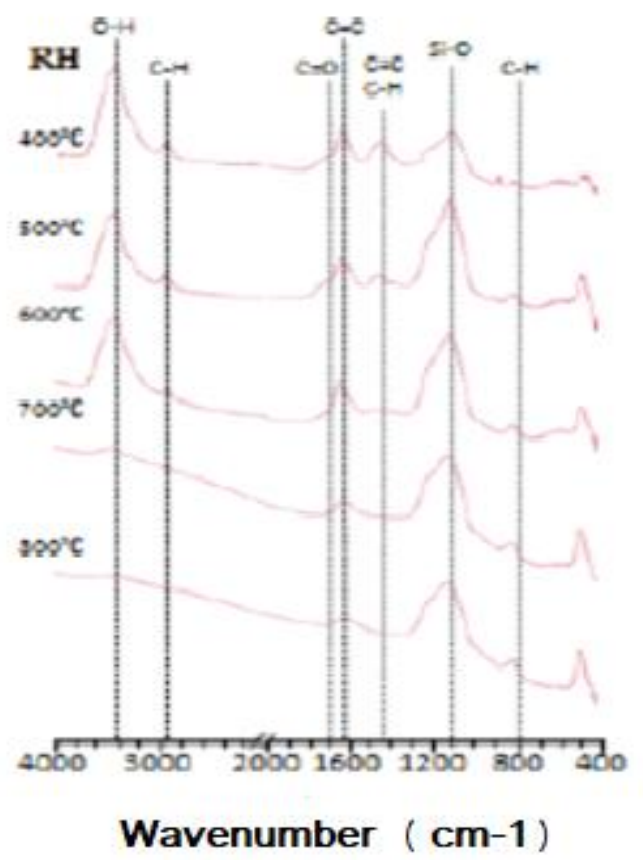

Fig. (10). Fourier transform infrared (FTIR) spectra of rice husk (RH) biochar in the range of wavelength 4000 to $400 \mathrm{~cm}^{-1}$

and bio-available contaminants and at the same time reduce soil $\mathrm{CO}_{2}$ emissions. The chemical composition of the low-temperature biochar $\left(500^{\circ} \mathrm{C}\right)$ is similar to that of the raw materials used for pyrolysis, whereas the properties of biochar produced at $500{ }^{\circ} \mathrm{C}$ (Table 4) showed that the $\mathrm{H} / \mathrm{C}$ ratio pointed out the carbonization rate. The decrease of this ratio was referred to the increase of aromaticity as indicated by Chen and Chen (2009). In addition, a reduced $\mathrm{O} / \mathrm{C}$ and $(\mathrm{O}+\mathrm{N}) / \mathrm{C}$ ratios represented a lower biochar polarity, which is also connected to the biochar stability as explained by Janus et al. (2015). Thus, biochar produced at lesser temperatures with lower aromaticity consisted primarily of lignin and cellulose, but the biochar produced at greater temperature was a kind of aromatic compound-rich material with smaller polarity (Sun et al., 2011). We chose the rice husk biochar produced at $500^{\circ} \mathrm{C}$ to $\mathrm{Fe}$ immobilization. From observation on the SEM image (Fig. 11), biochar generally exhibits macro-pores with internal diameter size of $10 \mu \mathrm{m}$. The macro-porosity $(>50 \mathrm{~nm})$ of biochar are relevant for soil aeration and water movement (Troeh and Thompson, 2005). Macro-pores also facilitate the root movement through the soil and act as the habitats for soil microbes (Saito and Muramoto, 2002). Hence, biochar has the ability to improve soil physical characteristics such as soil water retention and porosity. Basso et al. (2013) reported that the addition of biochar to sandy loam soil increased the water- holding capacity by $23 \%$ compared to the non-amended soil. Glaser et al. (2002) also found an increase in the soil field capacity with an increase of the biochar surface area and porous structure.

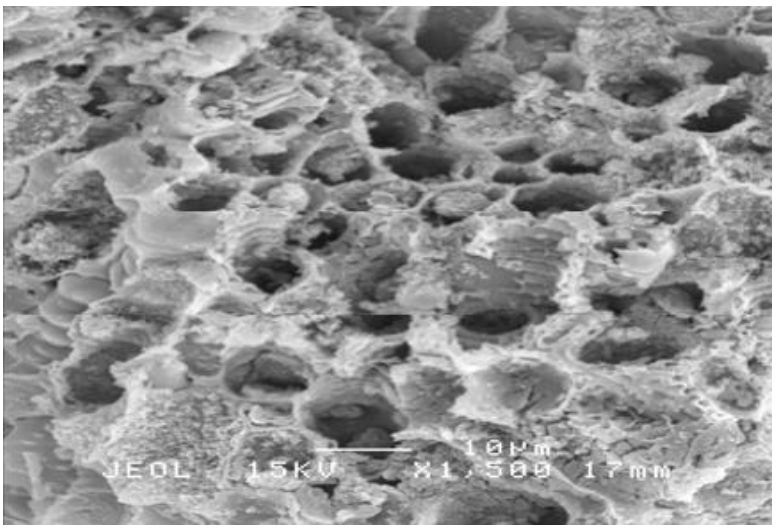

(a)

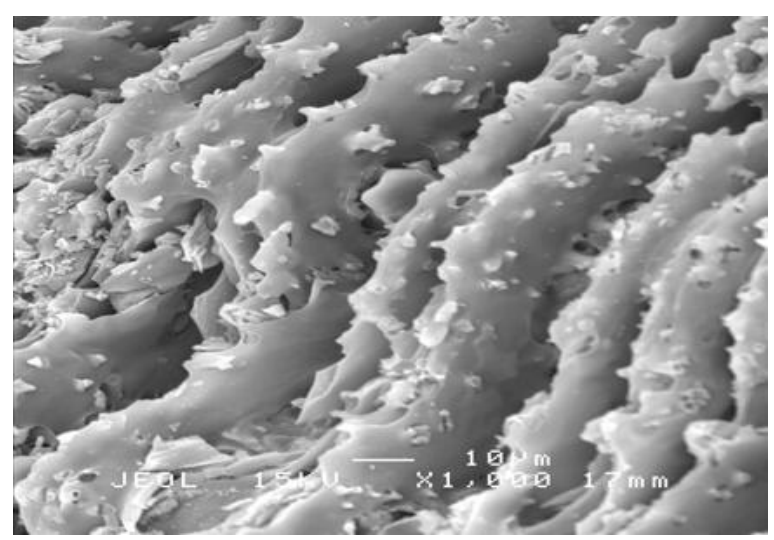

(b)

Figure (11). SEM image of rice husk biochar at (a) 1500 and (b) $1000 \mathrm{x}$ magnification

The Brunauer, Emmett and Teller (BET) surface area of biochar points out the physical changes in biomass during the pyrolysis process. The surface area relies largely on the carbon $(\mathrm{C})$ mass removed during the processing and creating pores in the materials (Zabaniotou et al., 2008). The sorption capacity of biochar can be determined from its surface area, where high surface area will increase the sorption capacity. Surface area and porosity of rice husk biochar are presented in Table 5. 
Citation: Sahar Mohamed Ismail; Sherine Shehata Marid and Doaa Taha Eissa Monitoring and Remediation of Environmental Aspects of Fe-rich Soils of Bahariya Oases and their Effects on peanut Quality Australian Journal of Basic and Applied Sciences, 13(9): 66-91. DOI: 10.22587/ajbas.2019.13.9.7

Table 5: BET surface area and porosity of Rice husk biochar

\begin{tabular}{|lcccc|}
\hline Biochar diameter & $\begin{array}{c}\text { BET surface area } \\
\left(\mathbf{m}^{\mathbf{2}} / \mathbf{g}\right)\end{array}$ & $\begin{array}{c}\text { Pore volume } \\
\left(\mathbf{c m}^{\mathbf{3}} / \mathbf{g}\right)\end{array}$ & $\begin{array}{c}\text { Pore surface } \\
\text { area }\left(\mathbf{m}^{\mathbf{2}} / \mathbf{g}\right)\end{array}$ & $\begin{array}{c}\text { Average pore } \\
(\mathbf{n m})\end{array}$ \\
\hline Rice husk & 23.22 & 0.01 & 1.41 & 4.34 \\
\hline
\end{tabular}

Biochar produced from RH had a large surface area. The high surface area of RH-biochar may indicate the adsorption capacity of heavy metals. In general, biochar surface area can be influenced by biochar's micropore volume, type of feedstock and pyrolysis processing condition (Boateng et al., 2007). The micropore volume of RH-biochar was $\sim 0.01 \mathrm{~cm}^{3} / \mathrm{g}$. The internal surface area of biochar representing the pore on the inner wall resulting from the interior crack was attributed to as micropore area. Meanwhile, the average pore diameter for biochar are in the range of mesopores diameters, with the internal pore width between 2 to $50 \mathrm{~nm}$. This indicates the potential of adsorption capacity RH-biochar in liquid-solid adsorption (Bagreev et al., 2001).

\section{b. Potassium humate}

The typical K-humate FT-IR spectrum in Fig. 12 is defined by the appearance of two strong Si-O-C bonding absorption bands at 1100 and $1050 \mathrm{~cm}^{-1}$. The sharp peak of carboxylate in the parental humate (CHS-K) spectrum at $1560 \mathrm{~cm}^{-1}$, indicating a large contribution of amide $>\mathrm{C}=\mathrm{O}$ (amide I) normally located at $1630-1695 \mathrm{~cm}^{-1}$. The presence of amide bond is also revealed by high peak strength at $1560 \mathrm{~cm}^{-1}$ (amide II and carboxylate) and a weak band at $1265 \mathrm{~cm}^{-1}$ (amide III) and those are in agreement with El-Hendawy, 2006.

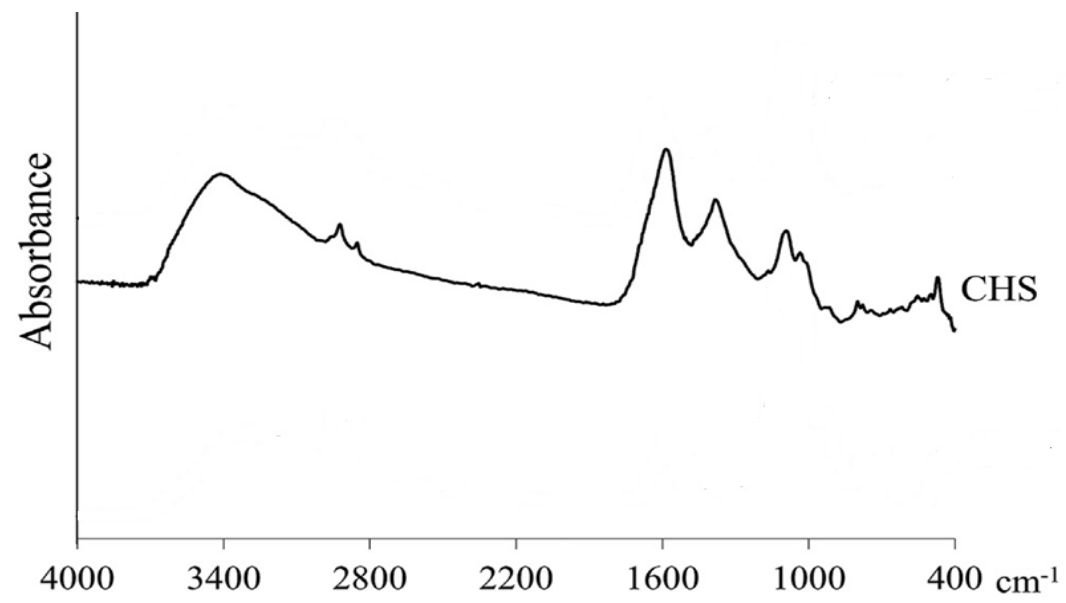

Fig. (12). Fourier transform infrared (FTIR) spectrum of potassium humate, CHS in the range of wave length 4000 to $400 \mathrm{~cm}^{-1}$.

\section{c. Sugar industry waste}

The X-ray diffraction pattern and FT-IR spectrum of sugar industry waste (SIW) are shown in Figure (13). A chemical composition of SIW is given in Table 4. Calcium is the main component of SIW, $46 \%$ of $\mathrm{CaO}$. The chemical composition of SIW was confirmed by XRD diffraction analysis. The XRD patterns are presented in Fig. 13a. The XRD pattern showed that $\mathrm{CaCO}_{3}$ was dominant in the sample that similar as mentioned by Wu Che-Ming and Lin Chun, 2005. The reflection intensities (I) and inter- planar spacing $(\mathrm{d}, \mathrm{nm})$ for SIW almost completely coincide with published data for calcium carbonate by Wu Che-Ming and Lin Chun, 2005. IR study has confirmed the results of X-ray diffraction analysis. IR spectra of the sample showed bands corresponding to $\mathrm{CaCO}_{3}$ that this is in consistent with results of Nakamo TO K., 1986. A strong band at $3300 \mathrm{~cm}^{-1}$ shows the likelihood of the hydroxyl linkage. This figure indicates a wide band between 3000 and $3800 \mathrm{~cm}^{-1}$ with little about 2900 and 2500 $\mathrm{cm}^{-1}$ indicating the existing on the surface of both free and hydrogen bonded $\mathrm{OH}$ groups and $\mathrm{Si}-\mathrm{OH}$ group, respectively. This stretching is refer to the surface silanol groups $(\mathrm{Si}-\mathrm{OH})$. The IR spectra noted that at about $1700 \mathrm{~cm}^{-1}$, weak and broad peaks linked to $-\mathrm{CO}$ and $-\mathrm{C}-\mathrm{OH}$ groups acquired from aldehydes and ketones. The transmittance in the region of $1100 \mathrm{~cm}^{-1}$ shows the existence of lactones. The band at $870 \mathrm{~cm}^{-1}$, which could be assigned to $\mathrm{T}-\mathrm{OH}$ bond $(\mathrm{T}=\mathrm{Si}$ or $\mathrm{Al})$, was discovered in the amorphous material precursor of zeolite. The signal focused at 623,626 and $668 \mathrm{~cm}^{-1}$ is assigned to inner vibration of ( $\mathrm{Si}$, $\left.\mathrm{Al}\right)-\mathrm{O}$ symmetric stretching according to Moisés et al., 2013. The Si-O stretching vibrations were noted at $710,712,668$ and $623 \mathrm{~cm}^{-1}$ indicating the existence of quartz, this is in agreement with findings of Marel and Bentelspacher, 1976. Bands in the regions 1400 $-700 \mathrm{~cm}^{-1}$ and $2500-1800 \mathrm{~cm}^{-1}$ can be attributed to the presence of $\mathrm{CO}_{3}{ }^{2-}$ and $\mathrm{CH}(\mathrm{CO})$ groups, respectively. IR results were very useful for identifying of different forms of minerals found in the samples. Table 4 demonstrates the compositions of different element oxides based on weight percentage (Wt. \%) of the samples. This analysis indicated that the sugar industry waste sample includes comparable and substantial amount of basic elements and several required properties that can justify their suitability as a pigment adsorbent by using therapy techniques in Fe-contaminated soil. 
Citation: Sahar Mohamed Ismail; Sherine Shehata Marid and Doaa Taha Eissa Monitoring and Remediation of Environmental Aspects of Fe-rich Soils of Bahariya Oases and their Effects on peanut Quality Australian Journal of Basic and Applied Sciences, 13(9): 66-91. DOI: 10.22587/ajbas.2019.13.9.7

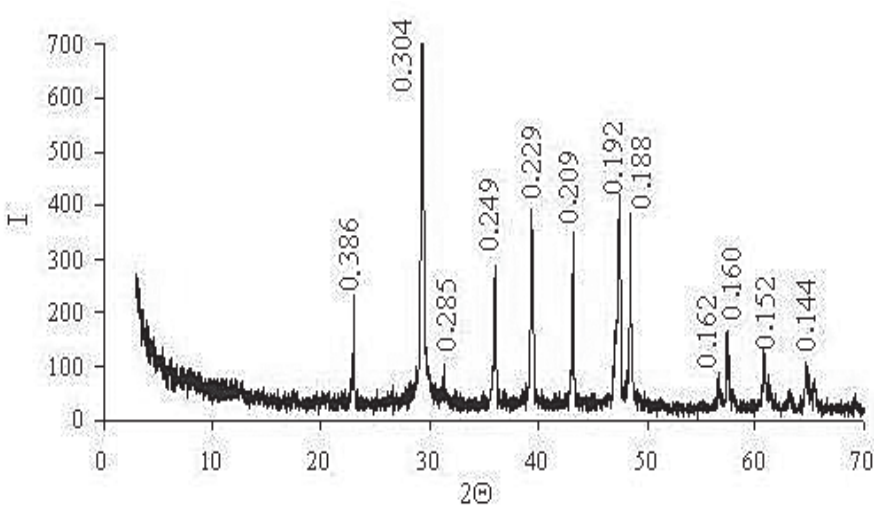

(a)

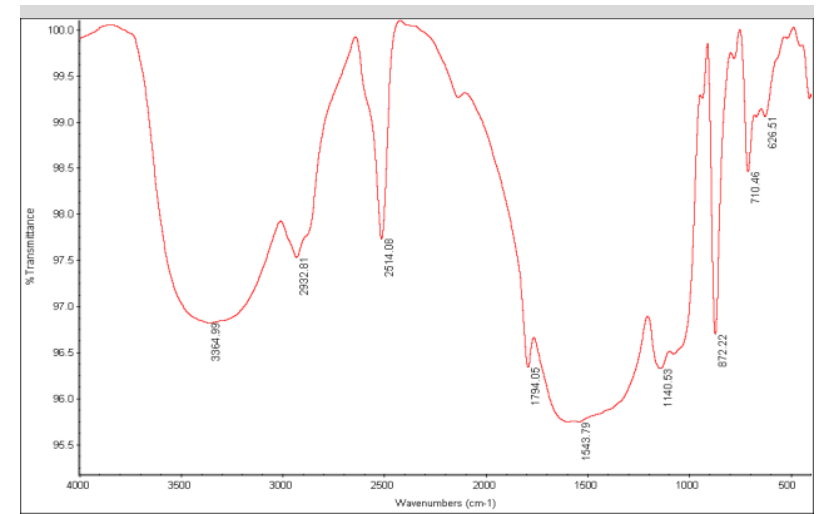

(b)

Fig. (13). X-ray diffraction pattern (a) and (b) Fourier transform infrared (FT-IR) spectrum of Sugar beet industry waste (SIW).

\subsection{Effect of different applied soil inorganic amendments on the removal of Fe-red pigment from peanut pods:}

\subsubsection{Gypsum treatment}

As shown in Fig. 7, the gypsum contained the stretching and deformation vibrations of the $\mathrm{O}-\mathrm{H}$ water bond at 3525 , 3492, $3401 \mathrm{~cm}^{-1}$ and at 1692 and $1627 \mathrm{~cm}^{-1}$, respectively. The hydroxyl groups demonstrated efficacy in immobilizing the Fe (III), this is clear in Fig. 14a, because of its ability to bind or complex with Fe-metal. This finding is in agreement with Basta et al., 2005. However, the precipitation appears to be predominant process of Fe (III) immobilization in the soil in the presence of anions such as sulfate $\left(\mathrm{SO}_{4}{ }^{2-}\right)$, especially when their concentration is high (Adriano 2001). This has actually led to the removal of red pigment from the peanut pods especially with higher additions of gypsum compared with the smaller ones and the control which led to a slight red Fe-pigment (Fig. 14b and c).

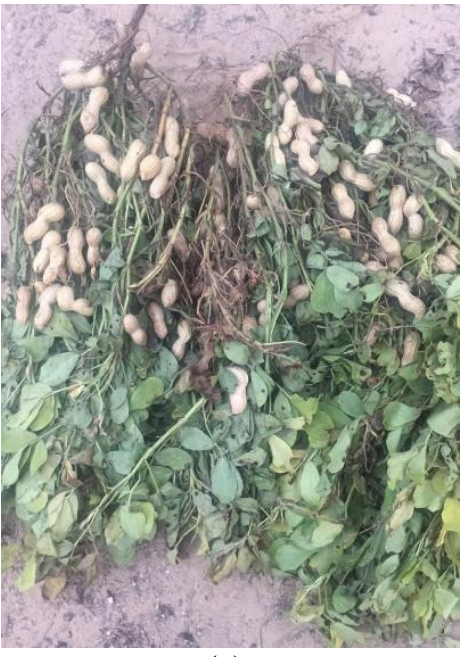

(a)

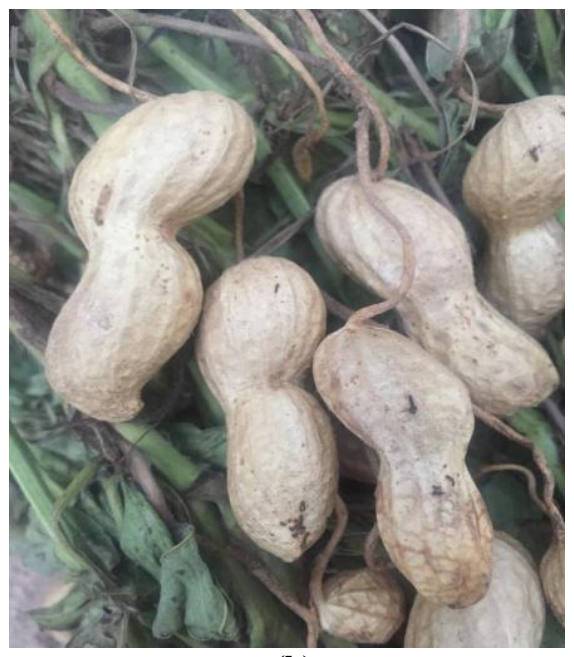

(b)

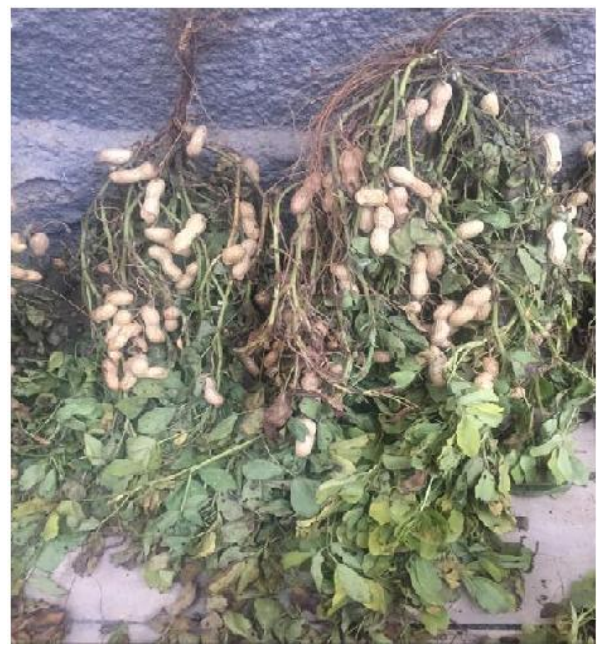

(c)

Fig. (14). Fe (III) immobilization as affected by the applied soil gypsum levels compared with control. Peanut pods without red- Fe (III) pigment at higher gypsum addition, $600 \mathrm{~kg} \mathrm{fed}^{-1}$ (a). Peanut pods with slight red-Fe (III) pigment at gypsum addition $500 \mathrm{~kg}^{-1}$ fed $^{-1}$ (b). Peanut pods without gypsum additions with red-Fe (III) pigment as control (c).

As shown in Table 6, the gypsum applications also improved clearly soil properties. The soil differed in $\mathrm{pH}$, electrical conductivity (ECe), sodium adsorption ratio (SAR), and exchangeable sodium percent (ESP) in the two depths compared with the control. The $\mathrm{pH}$ is non-significantly decrease in gypsum treated soil, may be referred to the replacement of exchangeable $\mathrm{Na}^{+}$by $\mathrm{Ca}^{2+}$ during $\mathrm{Na}^{+}-\mathrm{Ca}^{2+}$ exchange and the subsequent leaching of $\mathrm{Na}^{+}$ions. The reduction in $\mathrm{EC}_{\mathrm{e}}$ reached 5.86 and $17.26 \%$ due to application of the gypsum at the rates of 400 to $600 \mathrm{~kg}$ gypsum fed $^{-1}$, respectively, (Table 6). Sodium adsorption ratio (SAR) had significant $(\mathrm{P} \leq 0.05)$ reduction in all treatments compared with control (Table 6) ranging from $38.81\left(400 \mathrm{~kg} \mathrm{fed}^{-1}\right)$ to $61.84 \%$ $\left(600 \mathrm{~kg} \mathrm{fed}^{-1}\right)$. This reduction could be referred to replacement of $\mathrm{Na}$ as monovalent on the exchange complex by $\mathrm{Ca}^{2+}$ from the soil solution (Gharaibeh et al., 2009). Exchangeable sodium percentage (ESP) was significantly ( $\leq 0.05)$ lowered from 17.6 (control) to percentages of values ranging from 11.5 to 7.9 (Table 6) i.e. reduction percentages of $34.66,40.91$ and $55.11 \%$ occurred, due to application of 400,500 and $600 \mathrm{~kg}_{\text {gypsum }} \mathrm{fed}^{-1}$, respectively. The decreased ESP could be ascribed to desalinisation resulting from increased exchangeable efficiency of $\mathrm{Ca}^{2+}$ on the exchange complex (Amstrong and Tanton, 1992). As noticed in Table 7, gypsum treatments significantly decreased extractable $\mathrm{Fe}, \mathrm{Zn}, \mathrm{Cu}$, and $\mathrm{Cd}$ in post-peanut soil, with the decrease being great $\left(32.46,29.85,9.68\right.$ and $58.87 \%$ ) owing to application of gypsum at a rate of $400 \mathrm{~kg}^{-1}$ and least decrease $(1.33,15.11,1.27$ and $42.31 \%)$ due to application gypsum at rate of $600 \mathrm{~kg} \mathrm{fed}^{-1}$. This means that sandy soil attained lower concentrations of $\mathrm{Fe}, \mathrm{Zn}, \mathrm{Cu}$ and $\mathrm{Cd}$ due to gypsum addition at a rate of $400 \mathrm{~kg}^{-1}$. DTPA-extractable Mn concentration 
Citation: Sahar Mohamed Ismail; Sherine Shehata Marid and Doaa Taha Eissa Monitoring and Remediation of Environmental Aspects of Fe-rich Soils of Bahariya Oases and their Effects on peanut Quality Australian Journal of Basic and Applied Sciences, 13(9): 66-91. DOI: 10.22587/ajbas.2019.13.9.7

significantly increased in the postharvest soil with gypsum due to application of gypsum rates of 500 and $600 \mathrm{~kg}^{-1} \mathrm{compared}^{-1}$ to the control. No significant change occurred in Ni concentration due to application of gypsum (Table 7). Also, the applicat ion of gypsum caused significant increase in N, P, K, Fe, Mn, Zn in the shoots (Table 8). Generally, at the greater levels of gypsum, the greater the uptake of these elements owing to additional availability of plant nutrients from sparingly soluble hydroxide as well as from its own decomposition. On the other hand, it seems that gypsum treatments reduced $\mathrm{Cu}$ and Ni concentrations in the shoots, probably due to complexion of gypsum with $\mathrm{Cu}$ and $\mathrm{Ni}$ metals, which affected slow availability over longer time, and this indirectly also promoted plant growth (Nardi et al. 2002). The $\mathrm{Fe}, \mathrm{Mn}, \mathrm{Cu}, \mathrm{Ni}$ and Cd concentrations decreased in peanut grains (Table 8) with the gypsum additions, which might be due low translocation of these elements from shoot to grains (Cao et al. 2003). According to Bolan et al. (2003), $\mathrm{Ca}^{2+}$ addition as gypsum inhibited the translocation of these metals from root to shoot as these metals are accumulated primarily on cell walls of roots with only limited amounts translocated to shoot and grains. For N, P, $\mathrm{K}$ and $\mathrm{Zn}$, their concentrations significantly increased in the grains with high gypsum additions compared to the control referring to high translocation from shoot to grains with increasing rate of the applied gypsum (Table 8). The productivity per fedden of peanuts also increased with higher gypsum additions compared to control, where the rate of increase reached to 1.165 ton at 600 $\mathrm{kg} \mathrm{fed}^{-1}(61.11 \%)$ compared to the control $\left(0.72\right.$ ton fed $\left.{ }^{-1}\right)$. Also, the size of pod increased (i.e. pod quality) from $42 \mathrm{pod} / 100 \mathrm{~g}$ in control to $36 \mathrm{pod} / 100 \mathrm{~g}$ due to the highest gypsum addition $\left(600 \mathrm{~kg} \mathrm{feed}^{-1}\right)$. This is related to corresponding increase in pod densities that express the pod fullness degree (Table 8), i.e. pod quality increased markedly with increasing of gypsum additions.

\subsubsection{Phosphogypsum treatment}

From Figure 8, we can conclude that phosphate immobilized Fe. Phosphate-induced Fe deficiency in soil could be explained by (i) phosphate-induced immobilization of $\mathrm{Fe}^{3+}$ adsorption; and (ii) precipitation of $\mathrm{Fe}$ as $\mathrm{Fe}(\mathrm{OH})_{3}$ and $\mathrm{FePO}$. Several mechanisms can be advanced for phosphate-induced $\mathrm{Fe}^{3+}$ adsorption observed in this study. These include (i) increase in $\mathrm{pH}$; (ii) increase in surface charge; (iii) co-adsorption of phosphate and $\mathrm{Fe}$ as an ion pair; and (iv) surface complex formation of Fe on the phosphate. Specifically sorbed anions, such as phosphate, hydroxyl, and sulfate form complexes with the surface until cations are adsorbed onto the adsorbed anions (Bolland et al. 1977). Hence, surface complexation has also been suggested as a mechanism for the immobilization of Fe by phosphogypsum (Xu et al. 1994). Although there was no direct evidence of $\mathrm{Fe} \mathrm{PO}_{4}$ formation even at the highest level of phosphogypsum, it did not preclude the formation of mixed $\mathrm{Ca}-\mathrm{Fe}$ phosphate or the amorphous Fe phosphate compounds with different solubility product. In general, the solubility of $\mathrm{Fe} \mathrm{PO}_{4}$ has been shown to be too high to control the concentration of Fe in soil as indicated by Soon (1981). Thereby, effectively reducing red-Fe pigment on peanut pods with higher addition of phosphogypsum occurred (Fig. 15a) compared to smaller additions and control (Fig. 15b and c). These complexes may be formed because of the interaction of $\mathrm{Fe}$ with surface sites of oxides such as $\mathrm{Ca}-\mathrm{OH}, \mathrm{Fe}-\mathrm{OH}, \mathrm{Al}-\mathrm{OH}$ and $\mathrm{Si}-\mathrm{OH}$ found in PG. PG supplies appreciable of phosphorous to the soil in addition to increasing the $\mathrm{Ca}^{2+}$ levels (Alcordo and Rechcigl, 1993). In addition, the PG used in the study also contained $\mathrm{Mg}, \mathrm{Ca}, \mathrm{Si}$ and $\mathrm{Al}$. This refers to the presence of the inorganic components, which may be involved in the adsorption of Fe (III) and are bound lightly by those ions that form strong, complex OH groups on the surface of minerals. Qadir et al. (2013) found that the application of calcium supplying PG to soil significantly improved quality and productivity of this soil as indicated in Table 8. The phosphogypsum treatments improved soil chemical properties more than gypsum treatments that caused a slight decrease in soil $\mathrm{pH}$ (Table 6) with increasing application rates of PG. Our results pointed out that the soil $\mathrm{pH}$ decreased from 7.91 (control) to 7.80 with higher PG addition (Table 6), which is in agreement with Jarak et al. (2003). Soil electrical conductivity $\left(\mathrm{EC}_{\mathrm{e}}\right)$ was reduced by $14 \%$, due to increasing rate of the applied phosphor-gypsum from 400 to $600 \mathrm{~kg} \mathrm{PG} \mathrm{kg}^{-1}$ (Table 6) indicating moderate PG solubility (Mishra et al., 2003). Lee et al. (2009) have noticed enhanced levels of available $\mathrm{P}, \mathrm{SO}_{4}$ exchangeable $\mathrm{K}, \mathrm{Ca}$ and $\mathrm{Mg}$ with increasing rate of $\mathrm{PG}$ application. The phospho-gypsum increased the $\mathrm{S}_{-} \mathrm{SO}_{4}{ }^{2-}$ levels (Table 6). These results confirm those found by Michalovicz et al. (2014) and Pauletti et al. (2014). Increase the soil sulphate content has various implications. Zambrosi et al. (2007) studied ionic speciation involving sulphate and found higher susceptibility to formation of the pair between $\mathrm{SO}_{4}{ }^{2-}$ and $\mathrm{Ca}^{2+}$, however representing only $1 \%$ of the Ca ${ }^{2+}$ in solution, with more significant pair formation with $\mathrm{Mg}^{2+}, \mathrm{Al}^{3+}$ and $\mathrm{K}^{+}$(Caires et al. 2004). The layer 0.0-0.3 $\mathrm{m}$ had no decrease in $\mathrm{K}^{+}$ contents with increasing phosphogypsum rates. However, the soil $\mathrm{Ca}^{2+}$ content showed an increase (Table 6). Similar effects were observed by Carvalho et al. (2013), who found increases in $\mathrm{Ca}^{2+}$ and sulphate contents in the soil layer 0.0-0.30 $\mathrm{m}$ with the phosphogypsum additions, and a consequent increase in base saturation (V\%), which is directly related to the displacement of hydroxyl $\left(\mathrm{OH}^{-}\right)$and sulphate adsorption, enabling the formation of metal binder, increasing the cation exchange capacity $(\mathrm{CEC})$ predominantly related to the cation $\mathrm{Ca}^{2+}$. Sodium adsorption ratio $(\mathrm{SAR})$ had significant $(\mathrm{P} \leq 0.05)$ reduction in all treatments compared with control (Table 6) ranging from $44.08\left(400 \mathrm{~kg} \mathrm{fed}^{-1}\right)$ to $67.11 \%\left(600 \mathrm{~kg} \mathrm{fed}^{-1}\right)$. It was observed more reduction of SAR at higher PG additions, could be referred to replacement of $\mathrm{Na}^{+}$as monovalent on the exchange complex by $\mathrm{Ca}^{2+}$ from the soil solution (Gharaibeh et al., 2009). So, exchangeable sodium percentage (ESP) significantly (P $\leq 0.05)$ decreased from 17.6 (control) to values ranging from 10.7 to 7.0 resulting from PG additions (Table 5) representing reduction percentages of 39.20 , 40.91 and $50.00 \%$ for 400, 500 and $600 \mathrm{~kg}$ applied PG fed ${ }^{-1}$, respectively. The decreased ESP could be attributed to desalinisation resulting from increased exchangeable efficiency of $\mathrm{Ca}^{2+}$ on the exchange complex (Amstrong and Tanton, 1992). As showed in Table 7, phosphogypsum treatments significantly decreased extractable Fe, Mn, Zn, and Ni in post-peanut soil compared to control, with the decrease being greatest $(31.44,41.22,30.92$ and $6.58 \%)$ and least $(7.15,33.00,16.36$ and $2.88 \%)$ with gypsum additions at rates of 400 and $600 \mathrm{~kg} \mathrm{fed}^{-1}$, respectively. It observed that extractable $\mathrm{Cu}$ and Ni concentrations significantly increased in the postharvest soil with all PG treatments compared to the control (Table 7). Also, the application of PG caused significant increase in $\mathrm{N}, \mathrm{P}, \mathrm{K}, \mathrm{Fe}, \mathrm{Mn}$, and $\mathrm{Cu}$ in the shoots. Generally at the greater levels of PG, the concentration of these elements in the shoots increased compared to control owing to additional availability of plant nutrients from sparingly soluble 
Citation: Sahar Mohamed Ismail; Sherine Shehata Marid and Doaa Taha Eissa Monitoring and Remediation of Environmental Aspects of Fe-rich Soils of Bahariya Oases and their Effects on peanut Quality Australian Journal of Basic and Applied Sciences, 13(9): 66-91. DOI: 10.22587/ajbas.2019.13.9.7

sulphate, phosphate and hydroxide as well as from its own decomposition (Table 7). On the other hand, it appears that PG treatments reduced $\mathrm{Zn}$ and $\mathrm{Ni}$ concentrations in the shoots, due to more complexion of phosphate and/or carbonate with $\mathrm{Zn}$ and $\mathrm{Ni}$ metals (Nardi et al. 2002). Zn, Ni and Cd concentrations decreased in peanut grains with increasing PG additions compared to control, maybe due to their translocation from shoot to grains (Cao et al. 2003). According to Bolan et al. (2003), Ca ${ }^{2+}$ addition as PG inhibited the translocation of these metals from root to shoot as these metals are accumulated primarily on cell walls of roots with only limited amounts translocate to shoot and grains (Xiong 1997). The N, P, K, Fe and Zn concentrations significantly increased in the grains with higher PG additions compared to the control referring to high translocation of these elements from shoot to grains with increasing PG applications (Table 8). The productivity per fedden of peanuts also increased with highest PG additions compared to other gypsum treatments and control, where the greatest rate of increase reached 1.349 ton at a rate of 600 $\mathrm{kg} \mathrm{fed}^{-1}(86.48 \%)$ compared to the control ( $\left.0.72 \mathrm{ton}\right)$. Also, the size of pod increased (i.e. pod quality) from $42 \mathrm{pod} / 100 \mathrm{~g}$ in the control treatment to $35 \mathrm{pod} / 100 \mathrm{~g}$ at the highest $\mathrm{PG}$ addition $\left(600 \mathrm{~kg}\right.$ feed $\left.{ }^{-1}\right)$, which related to more increase of pod densities than those in gypsum treatments (Table 8).

\subsubsection{Sulphur treatment}

Fig. 9 implied presence of $\mathrm{O}=\mathrm{S}=\mathrm{O}$ and some aromatic, alkyne and alkene groups. One important fact is the oxidation of $\mathrm{S}$ to $\mathrm{S}_{-} \mathrm{SO}_{4}{ }^{2-}$ by certain groups of acidophilic bacteria notably thiobacillus spp. Some elements, including iron, zinc, and copper precipitate as sulfides and sulfates to produce forms that are relatively immobile in the soil profile (Kabata-Pendias 1992). On the other hand, metal can form inorganic ligands with $\mathrm{S}_{-} \mathrm{SO}_{4}{ }^{2-}$ (Mclaughlin et al., 1996). Indeed, the elemental sulfur addition resulted in the noticeable presence of $\mathrm{SO}_{4}{ }^{2-}$ concentration in the soil and increased with $\mathrm{S}$ applications and the solubility of the Fe was significantly increased in all treatments with $\mathrm{S}$ application and can enhance metal uptake by peanut plants. No Fe-complexes were formed for Fe- immobilization (only few Fe (III)-sulfides, sulfate and inorganic ligands) and thus application of S did not affect the removal of Fe-red pigment from peanut pods even with high sulfur additions as shown in Fig. 16. The higher addition of $\mathrm{S}$ (200 kg S fed ${ }^{-1}$ ) appeared slightly Fe (III)-red pigment. It has been suggested that elemental S can be used to reduce soil $\mathrm{pH}$ and increase solubility of some metals in soils (Kayser et al. 2000). The mobile fraction of soil metals is strongly affected by soil pH, and, generally, $\mathrm{S}$ increases as soil $\mathrm{pH}$ decreases (Kayser et al. 2000). The $\mathrm{pH}_{\mathrm{s}}$ of soil at the start of experiment (control) was 7.88 and 7.94 at 0-30 and 30-60 cm depths, respectively (Table 6). Post-harvest peanut soil $\mathrm{pH}_{\mathrm{s}}$ were significantly decreased especially at 0-30 $\mathrm{cm}$ soil depth (Table 6). Maximum $\mathrm{pH}_{\mathrm{s}}$ decreasing in post-peanut soil was observed at highest $\mathrm{S}$ addition (200 kg fed ${ }^{-1}$ ) and it was 3.55 and $2.89 \%$ larger in 0-30 and 30-60 cm depths, respectively. Minimum $\mathrm{pH}_{\mathrm{s}}$ decreasing in post-peanut soil was observed at lowest $\mathrm{S}$ addition $\left(100 \mathrm{~kg} \mathrm{fed}^{-1}\right)$ whose reduction values were 2.41 and $1.89 \%$ in $0-30$ and $30-60 \mathrm{~cm}$ depths, respectively compared to control. Post-harvest soil differed in $\mathrm{pH}$, electrical conductivity (ECe), Sodium adsorption ratio (SAR), and exchangeable sodium percent (ESP) in the two depths compared with the control (Table 6). The mean reduction of ECe reached 33.38 to $24.75 \%$ due to increasing the sulpher application rate from 100 to $200 \mathrm{~kg}$ sulphur fed ${ }^{-1}$, respectively, (Table 6 ).

Table (6). Effect of different inorganic amendments on some chemical characteristics of post-peanut soil irrigated by with well water pivot.

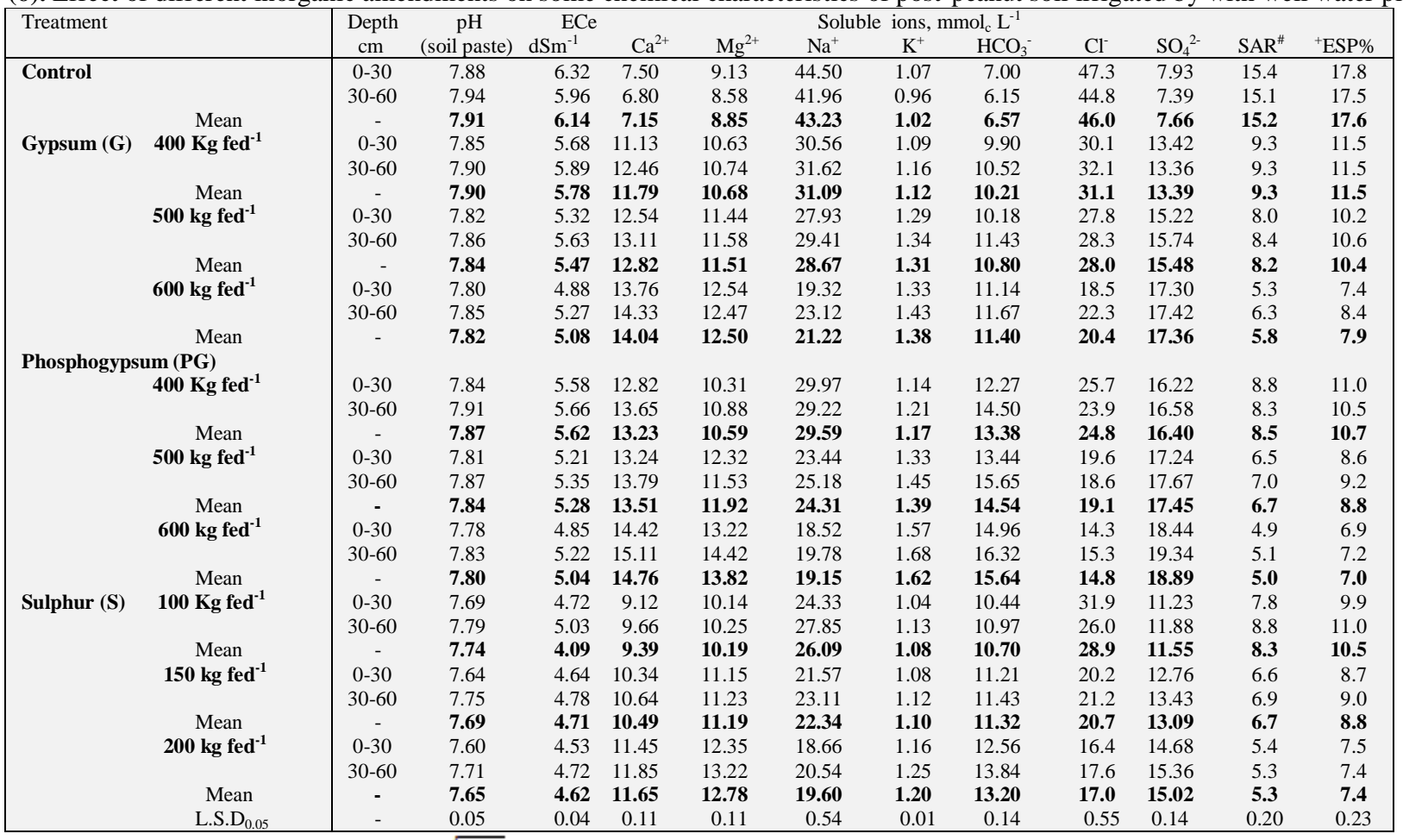

*SAR: Sodium Adsorption Ratio: $\left.\mathrm{Na}^{+} / \sqrt{(\mathrm{Ca}}+\mathrm{Mg}\right) / 2$

${ }^{+}$ESP: calculated by equation $1.95+1.03$ SAR (Mohsen, 2009). 
Citation: Sahar Mohamed Ismail; Sherine Shehata Marid and Doaa Taha Eissa Monitoring and Remediation of Environmental Aspects of Fe-rich Soils of Bahariya Oases and their Effects on peanut Quality Australian Journal of Basic and Applied Sciences, 13(9): 66-91. DOI: 10.22587/ajbas.2019.13.9.7

Table (7). Effect of different inorganic amendments on soil DTPA-extractable heavy metal contents of post-peanut soil irrigated by well water

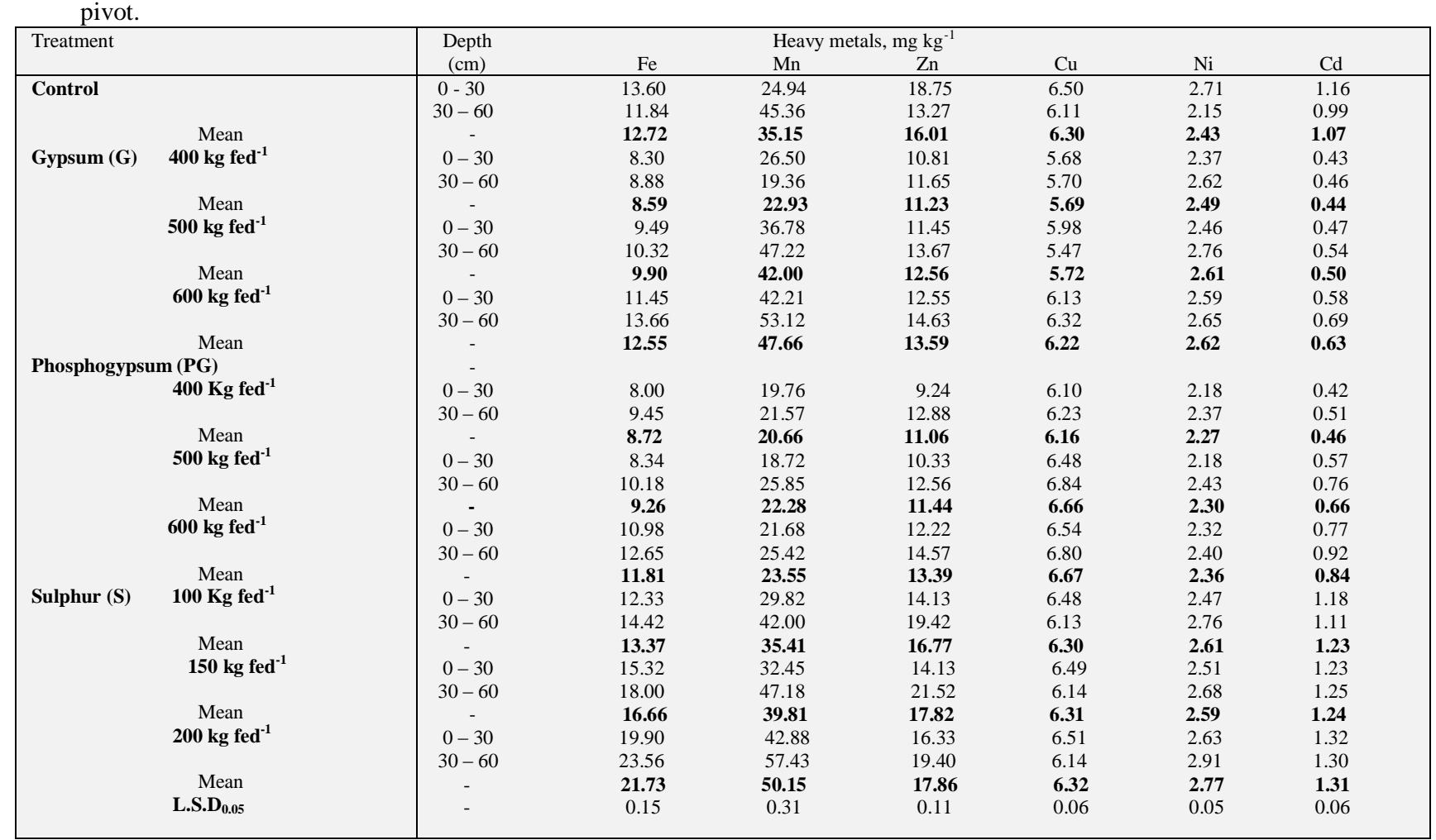

Table (8). Pod yields, weight of 100 pods, NPK and heavy metals concentrations of peanut shoot and grains cultivated in Bahariya Oases soil as affected by different Fe-inorganic amendments and irrigated by well water pivot.

\begin{tabular}{|c|c|c|c|c|c|c|c|c|c|c|c|c|c|}
\hline Treatment & & $\begin{array}{l}\text { Pods yield } \\
\left(\mathrm{kg} / 100 \mathrm{~m}^{2}\right)\end{array}$ & $\begin{array}{l}\text { weight of } 100 \\
\text { pods }(\mathrm{g})\end{array}$ & $\begin{array}{c}\text { Part of } \\
\text { plant }\end{array}$ & $\begin{array}{l}\mathrm{N} \\
(\%)\end{array}$ & $\begin{array}{l}\mathrm{P} \\
(\%)\end{array}$ & $\begin{array}{l}\mathrm{K} \\
(\%)\end{array}$ & $\begin{array}{c}\mathrm{Fe} \\
\left(\mathrm{mg} \mathrm{kg}^{-1}\right)\end{array}$ & $\begin{array}{c}\mathrm{Mn} \\
\left(\mathrm{mg} \mathrm{kg}^{-1}\right)\end{array}$ & $\begin{array}{c}\mathrm{Zn} \\
\left(\mathrm{mg} \mathrm{kg}^{-1}\right)\end{array}$ & $\begin{array}{c}\mathrm{Cu} \\
\left(\mathrm{mg} \mathrm{kg}^{-1}\right)\end{array}$ & $\begin{array}{c}\mathrm{Ni} \\
\left(\mathrm{mg} \mathrm{kg}^{-1}\right)\end{array}$ & $\begin{array}{c}\mathrm{Cd} \\
\left(\mathrm{mg} \mathrm{kg}^{-1}\right) \\
\end{array}$ \\
\hline \multirow[t]{2}{*}{ Control } & & 17.23 & 222.5 & Shoot & 0.63 & 0.10 & 1.04 & 1204 & 107 & 82.0 & 63.7 & 3.18 & 1.07 \\
\hline & & & & Grains & 0.45 & 0.15 & 0.45 & 833 & 82.1 & 51.5 & 32.3 & 1.31 & 1.41 \\
\hline \multirow[t]{6}{*}{ Gypsum (G) } & $400 \mathrm{~kg} \mathrm{fed}^{-1}$ & 19.14 & 226.0 & Shoot & 1.66 & 0.31 & 2.12 & 1739 & 106 & 90.9 & 33.2 & 1.95 & 1.48 \\
\hline & & & & Grains & 1.99 & 0.21 & 0.48 & 548 & 81.6 & 56.2 & 25.3 & 1.07 & 0.59 \\
\hline & $500 \mathrm{~kg} \mathrm{fed}^{-1}$ & 24.84 & 239.4 & Shoot & 1.89 & 0.42 & 2.38 & 1865 & 111 & 96.6 & 36.5 & 1.86 & 1.50 \\
\hline & & & & Grains & 2.18 & 0.33 & 0.65 & 678 & 75.4 & 47.6 & 27.6 & 1.05 & 0.60 \\
\hline & $600 \mathrm{~kg} \mathrm{fed}^{-1}$ & 27.76 & 246.3 & Shoot & 1.97 & 0.57 & 2.46 & 1948 & 119 & 106 & 38.7 & 1.90 & 1.67 \\
\hline & & & & Grains & 2.24 & 0.44 & 0.81 & 766 & 73.0 & 54.9 & 28.6 & 1.12 & 0.73 \\
\hline \multicolumn{14}{|c|}{ Phosphogypsum (P } \\
\hline & $400 \mathrm{Kg} \mathrm{fed}^{-1}$ & 23.61 & 226.6 & Shoot & 2.42 & 0.23 & 3.12 & 2218 & 186 & 41.0 & 52.4 & 1.29 & 1.12 \\
\hline & & & & Grains & 2.72 & 0.16 & 0.31 & 838 & 85.6 & 28.1 & 38.3 & 0.87 & 0.24 \\
\hline & $500 \mathrm{~kg} \mathrm{fed}^{-1}$ & 27.21 & 235.3 & Shoot & 2.83 & 0.34 & 4.33 & 2773 & 212 & 57.3 & 64.5 & 1.42 & 1.35 \\
\hline & & & & Grains & 3.10 & 0.21 & 0.47 & 948 & 88.3 & 32.4 & 58.4 & 1.02 & 0.43 \\
\hline & $600 \mathrm{~kg} \mathrm{fed}^{-1}$ & 32.13 & 245.4 & Shoot & 3.08 & 0.49 & 6.73 & 3100 & 233 & 68.2 & 71.3 & 1.68 & 1.62 \\
\hline & & & & Grains & 3.30 & 0.27 & 0.59 & 970 & 95.8 & 36.2 & 63.4 & 1.30 & 0.89 \\
\hline \multirow[t]{8}{*}{ Sulphur (S) } & $100 \mathrm{Kg} \mathrm{fed}^{-1}$ & 35.17 & 238.2 & Shoot & 3.04 & 0.60 & 4.81 & 2872 & 108 & 85.4 & 64.3 & 1.58 & 1.92 \\
\hline & & & & Grains & 2.70 & 0.18 & 0.56 & 643 & 83.1 & 53.2 & 33.1 & 1.12 & 1.46 \\
\hline & $150 \mathrm{~kg} \mathrm{fed}^{-1}$ & 38.26 & 242.2 & Shoot & 3.83 & 0.73 & 7.45 & 3212 & 110 & 93.8 & 64.9 & 1.77 & 2.03 \\
\hline & & & & Grains & 2.98 & 0.23 & 0.74 & 878 & 83.8 & 67.1 & 35.4 & 1.23 & 1.54 \\
\hline & $200 \mathrm{~kg} \mathrm{fed}^{-1}$ & 42.56 & 248.1 & Shoot & 4.76 & 0.88 & 9.88 & 3856 & 111 & 112 & 65.9 & 1.89 & 2.14 \\
\hline & & & & Grains & 3.32 & 0.29 & 0.95 & 997 & 84.6 & 89.6 & 38.4 & 1.28 & 1.58 \\
\hline & L.S.D 0.05 & 3.84 & 2.90 & Shoot & 0.06 & 0.006 & 0.08 & 16.5 & 1.22 & 0.68 & 0.64 & 0.06 & 0.08 \\
\hline & & & & Grains & 0.03 & 0.004 & 0.006 & 6.53 & 1.03 & 0.72 & 0.70 & 0.03 & 0.003 \\
\hline
\end{tabular}


Citation: Sahar Mohamed Ismail; Sherine Shehata Marid and Doaa Taha Eissa Monitoring and Remediation of Environmental Aspects of Fe-rich Soils of Bahariya Oases and their Effects on peanut Quality Australian Journal of Basic and Applied Sciences, 13(9): 66-91. DOI: 10.22587/ajbas.2019.13.9.7

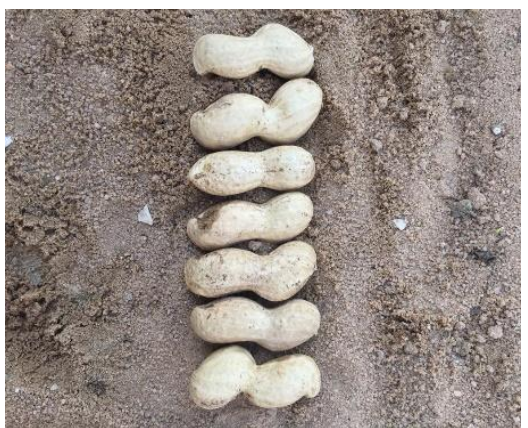

(a)

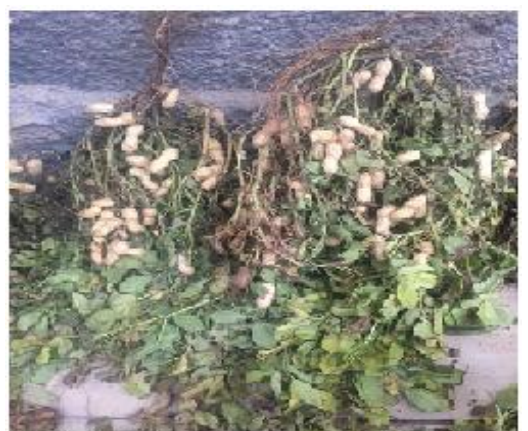

(b)

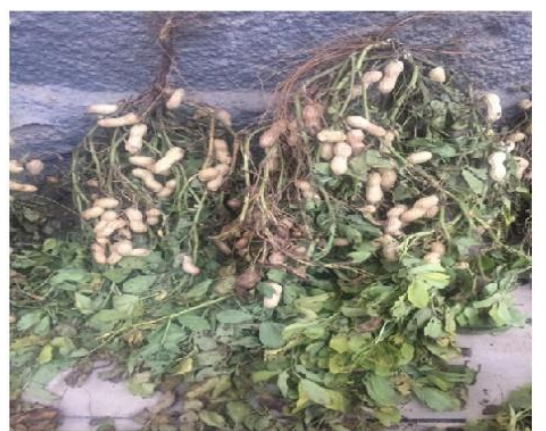

(c)

Fig. (15). Fe (III) immobilization as affected by the applied soil phosphogypsum levels compared with control. Peanut pods without red-Fe (III) pigment at higher PG addition, $600 \mathrm{~kg} \mathrm{fed}^{-1}$ (a). Peanut pods with slight red-Fe (III) pigment at PG addition $500 \mathrm{~kg} \mathrm{fed}^{-1}$ (b). Peanut pods without PG additions with red-Fe (III) pigment as control (c).

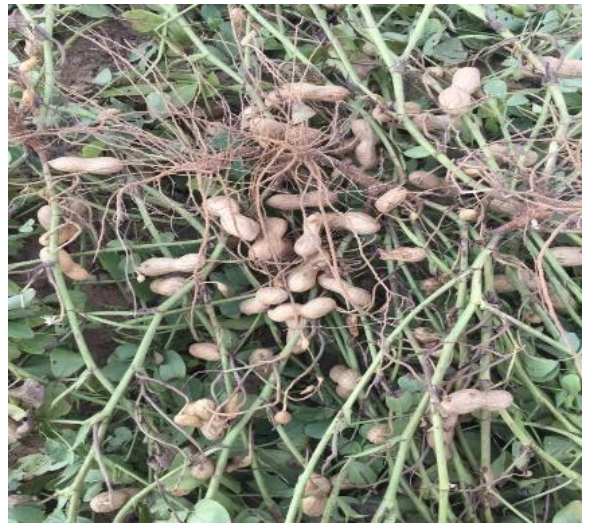

(a)

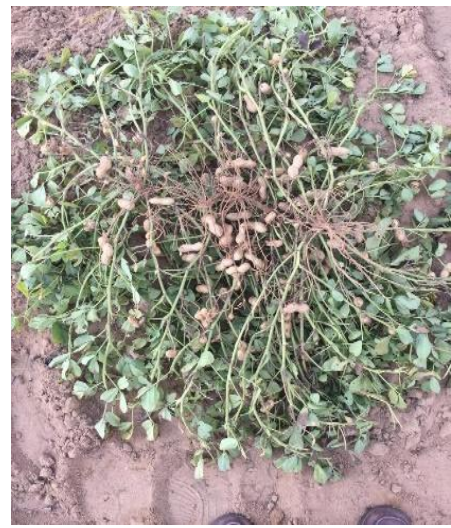

(b)

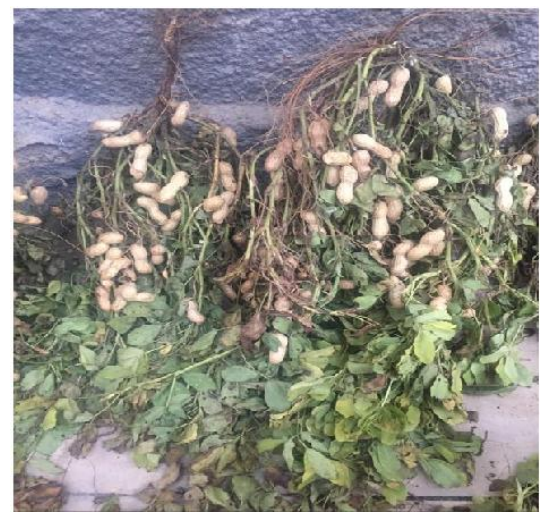

(c)

Fig. (16). Fe (III) immobilization as affected by the applied soil sulpher levels compared with control. Peanut pods with slightly Fe (III)-red pigment at higher $\mathrm{S}$ addition, $200 \mathrm{~kg} \mathrm{fed}^{-1}$ (a). Peanut pods with Fe (III)-red pigment at $\mathrm{S}$ addition $500 \mathrm{~kg}^{-1}$ fed (b). Peanut pods without $\mathrm{S}$ additions with Fe (III)-red pigment as control (c).

(SAR) had significant $(\mathrm{P} \leq 0.05)$ mean reduction due to all $\mathrm{S}$ treatments compared with control (Table 6). This reduction could be due to replacement of $\mathrm{Na}^{+}$as monovalent cation on the exchange sites by $\mathrm{Ca}^{2+}$ from the soil solution (Gharaibeh et al., 2009). Exchangeable sodium percentage (ESP) was significantly $(\mathrm{P} \leq 0.05)$ reduced from 17.6 (control) due to $\mathrm{S}$ treatment to values ranging from 10.5 to 7.4 (Table 6) corresponding reduction percentages of 40.34, 50.00 and $57.95 \%$ for 100 , 150 and 200 $\mathrm{kg} \mathrm{S}$ fed $^{-1}$, respectively. The decreased ESP could be ascribed to desalinisation resulting from increased exchangeable efficiency of $\mathrm{Ca}^{2+}$ on the exchange sites (Amstrong and Tanton, 1992). As observed in Table (6), S treatments significantly increased soluble $\mathrm{S}_{-} \mathrm{SO}_{4}{ }^{2-}$ concentrations with increasing $\mathrm{S}$ additions compared to control. The highest and least mean increase values of soluble $\mathrm{S}$ $\mathrm{SO}_{4}{ }^{2-}$ concentrations were 96.08 and $50.78 \%$ for 100 and $200 \mathrm{~kg} \mathrm{~S} \mathrm{fed}^{-1}$, respectively. At Post-harvest peanut soil, soil extractable $\mathrm{Zn}$ concentration changed a little with S application that mean Zn concentration ranged from 16.01 (control) to $17.86 \mathrm{mg} / \mathrm{kg}$ (200 $\mathrm{kg} \mathrm{fed}^{-1}$ ), irrespective of sulphur applied dose. This is in agreement with the results of Kaya et al. (2009). Copper concentration tended to increase in the treatment with sulphur at rate of $200 \mathrm{~kg} \mathrm{fed}^{-1}$, however, no significant change occurred in the copper content of soil and these data went almost to similar results of Martinez et al. (2000). Fe, Mn, Ni and Cd markedly increased with soil $\mathrm{pH}$ decrease for all rates of sulphur application. One of the adverse effects of sulphur application is an increase in Mn solubility and the mobilization of heavy metals from both natural and anthropogenic sources (James and Riha 1984). Extractable $\mathrm{Fe}, \mathrm{Mn}, \mathrm{Ni}$ and $\mathrm{Cd}$ in post-peanut soil increased by the highest percentages i.e. $70.83,42.67,13.99$ and $22.43 \%$, however, with least percentages i.e. 5.11, 2.16, 7.41 and $14.95 \%$ due to sulphur addition at the rates 100 and $200 \mathrm{~kg}^{-1}$, respectively (Table 7) compared to control. This means that $\mathrm{S}$-amended sandy soil supplied greater concentrations of extractable-Fe, $\mathrm{Mn}, \mathrm{Ni}$ and $\mathrm{Cd}$ due to sulphur addition at a rate of $200 \mathrm{~kg} \mathrm{fed}^{-1}$ which might be due to less adsorption and fixation of these metals in S-amended coarse-textured soils (Singh et al., 2003). Also, application of sulfur was more effective on increasing $\mathrm{N}$ concentration in shoot and peanut grains. It was observed that addition of $200 \mathrm{~kg} \mathrm{~S}^{-1} \mathrm{f}^{-1}$ increased the $\mathrm{N}$ concentration to 4.76 and $3.32 \%$ as compared with control (0.63 and $0.45 \%)$ in shoot and grains, respectively (Table 8). The results in Table (8) reveal that application of sulphur increased the P-concentration in shoots and grains, due to the acidification effect of the rhizospere through oxidation products of sulphur which can mobilize considerable amounts of phosphorous (Khater, 1981). Potassium concentration was affected by the maximum S-application $\left(200 \mathrm{~kg} \mathrm{fed}^{-1}\right)$ and $\mathrm{K}$ increased significantly in both shoots and grains by 9.88 and $0.95 \%$, respectively. Singh et al., (1995) found that S application increased N, K and S of groundnut plants on alkaline calcareous soil. Table (8) indicates that sulphur application increased Fe content and the increase was more obvious by increasing the sulphur applied rates. This may be ascribed to the formation of sulphuric acid and consequently the decrease in soil $\mathrm{pH}$ which increased extractable iron in the soil. No significant change occurred in $\mathrm{Mn}$ or $\mathrm{Cu}$ contents in relation to rate of the $\mathrm{S}$-application in both 
Citation: Sahar Mohamed Ismail; Sherine Shehata Marid and Doaa Taha Eissa Monitoring and Remediation of Environmental Aspects of Fe-rich Soils of Bahariya Oases and their Effects on peanut Quality Australian Journal of Basic and Applied Sciences, 13(9): 66-91. DOI: 10.22587/ajbas.2019.13.9.7

shoots and grains. On the other hand, the concentrations of $\mathrm{Zn}$ and $\mathrm{Cd}$ in both peanut shoots and grains increased with the increase in the rate of the applied sulphur than without sulphur. Compared to without application of S (control), concentrations of $\mathrm{Zn}$ increased in peanut shoot by $4.15,14.39$ and $36.58 \%$ and in grains by 3.3, 30.29 and $73.98 \%$ with application of S at the rate of 100,150 and $200 \mathrm{~kg} \mathrm{fed}^{-1}$, respectively. Cd concentration increased in peanut shoot by $79.44,89.72$ and $100 \%$ and in peanut grains by $3.54,9.22$ and $12.05 \%$ owing to the application of $\mathrm{S}$ at the rates 100,150 and $200 \mathrm{~kg} \mathrm{fed}^{-1}$, respectively (Table 8). There are certain groups of acidophilic soil bacteria in the soil, predominantly the genus thiobacillus, which can oxidize $\mathrm{S}$ and change it to $\mathrm{SO}_{4}{ }^{2-}$ and hence, soil pH decreased (Kayser et al., 2000). Finally, extractable Ni decreased in peanut shoot by $50.31,44.34$ and $40.56 \%$ and in peanut grains by $14.50,6.11$ and $2.29 \%$ due to $\mathrm{S}$ application at the rates of 100,150 and $200 \mathrm{~kg}$ fed ${ }^{-1}$, respectively. This reduction is attributed to that $\mathrm{Ni}$ is an immobile metal in soil since it readily forms a precipitate with a low aqueous solubility within the soil matrix (Martinez and Motto, 2000). In addition, many plants retain Ni in their roots via sorption and precipitation with minimal transport to the harvestable plant portions (Kumar et al., 1995). The peanut productivity per fedden increased with highest sulphur additions compared to control and lower S rates, where the increase has been reached 1,787 ton at $200 \mathrm{~kg} \mathrm{fed}^{-1}$ compared to the control ( 0.72 ton). Also, the size of pod increased (i.e. pod quality) from $42 \mathrm{pod} / 100 \mathrm{~g}$ as control to $34 \mathrm{pod} / 100 \mathrm{~g}$ at highest sulphur addition rate $\left(200 \mathrm{~kg} \mathrm{fed}^{-1}\right)$ as shown in Table 8.

\subsection{Effect of different applied soil organic amendments on the removal of Fe-red pigment from peanut pods: \\ 2.4.1. Rice Husk Biochar treatment}

\section{In-Situ immobilization of Fe and other heavy metals in soil by RH biochar}

The removal of heavy metals by biochar is mainly reflected in two aspects: One is the sorption of heavy metals in the pores of biochar to reduce the residual amount in the soil; the other is the ion exchange or redox reaction between the effective components in biochar and heavy metal ions to stabilize the formation of heavy metal precipitates or to reduce toxicity by transforming them into low-valent states (Browdowski et al., 2005). Thus, it was observed that the removal Fe-red pigment on the peanut pods with percent $100 \%$ due to the highest rate of the applied RH biochar (Fig.17a) compared to the other lower biochar rates and control (Fig. 17b and c). Surface sorption of Fe (III) into biochar can be due to the complexion of the Fe with different functional groups (e.g., O-alkylated carbons and anomeric $\mathrm{O}-\mathrm{C}-\mathrm{O}$ carbons as well as fused-ring aromatic structures and aromatic C-O groups) present in the biochar (Uchimiya et al. 2011) as shown in Fig. 10 and Table 4. The exchange of Fe proceeds with cations associated with biochar, such as $\mathrm{Ca}^{2+}$ and $\mathrm{Mg}^{2+}$ ( $\mathrm{Lu}$ et al. 2012), $\mathrm{K}^{+}$and $\mathrm{Na}^{+}$(Uchimiya et al. 2011), or due to physical adsorption ( $\mathrm{Lu}$ et al. 2012). Biochar can also reduce the mobility of heavy metals, altering their redox state. Indeed, biochar is a reductant, but its electrochemical properties are dependent on the temperature and the concentration of the various redox-active minerals. Hence, when biochars are added to soils, they interact with plant roots, soil organic matter and microorganisms to form organo-mineral- biochar complexes (Joseph et al. 2015). Uchimiya et al. (2010) suggested that biochar application can increase the soil $\mathrm{pH}$ and cation exchange capacity and subsequently enhance the immobilization of heavy metals in soil.

\section{Effect of rice husk biochar on soil properties}

Addition of the highest rate of RHB ( 3 ton $\mathrm{fed}^{-1}$ ) to soil increased the mean pH value by 0.6 units from 7.55 (control) to 8.16, but the $\mathrm{pH}$ increase was not significant $(\mathrm{P} \leq 0.05)$. This is in line with Lu et al. (2014) who found that soil $\mathrm{pH}$ will increase by adding rice straw biochar. The RHB could increase soil $\mathrm{pH}$ through the hydrolysis of alkaline metal ion, which produces $\mathrm{OH}^{-}$into the soil from the ash of biochar (Glaser et al., 2002). All RH biochar treatments had no differences in their influences on soil pH, as shown in Table (9). Rice husk biochar had a significantly highest mean EC value $\left(6.33 \mathrm{dSm}^{-1}\right)$ with the RHB rate $\left(3\right.$ ton fed $\left.{ }^{-1}\right)$ compared to control $\left(5.48 \mathrm{dSm}^{-1}\right)$. This means that rice husk biochar had great quantities of dissolved ions (Table 9). Based on that (SAR) showed significant $(\mathrm{P} \leq 0.05)$ mean reduction due to all $\mathrm{RH}$ biochar treatments compared with control (Table 9) ranging from greatest percentages of 59.87 due to the applied of 1 ton fed ${ }^{-1}$ to least percentage of $54.14 \%$ due to the applied 3 ton fed ${ }^{-1}$. This EC reduction increased by decreasing the rate of the applied, probably because the highest rate of RH biochar contained the greatest amounts of soluble ions. Exchangeable sodium percentage (ESP) was significantly (P $\leq 0.05)$ decreased from 18.3 (control) to 9.4 (highest rate of RH biochar), table 9 that means reduction percentages of $56.02,52.88$ and $50.78 \%$ due to the

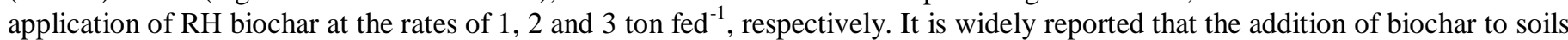
can result in an increase in $\mathrm{pH}$ and decline of metal solubility (Dai et al., 2017). From Table 10, it can be detected that extractable$\mathrm{Fe}, \mathrm{Mn}, \mathrm{Zn}, \mathrm{Cu}, \mathrm{Ni}$ and $\mathrm{Cd}$ concentrations were significantly $(\mathrm{P} \leq 0.05)$ decreased with increasing $\mathrm{RH}$ biochar additions. Mean decreasing as \% of $\mathrm{Fe}, \mathrm{Mn}, \mathrm{Zn}, \mathrm{Cu}, \mathrm{Ni}$, and $\mathrm{Cd}$ were $(49.29 ; 40.62 ; 32.10 ; 2.22 ; 39.09$ and $56.07 \%$, respectively, due to the greatest rate of the applied biochar $\left(3\right.$ ton $\left.\mathrm{fed}^{-1}\right)$ while least reduction percentages were $23.82 ; 14.82 ; 13.61 ; 0.32 ; 20.57$ and 28.97 $\%$, respectively, due to the lowest rate of biochar $\left(1\right.$ ton $\left.\mathrm{fed}^{-1}\right)$. These findings may indicate that heavy metals could be adsorbed by the same sites and functional groups, while competing with other metals to form a reciprocal inhibition, thus lead to decline in extractable-metal concentrations. $\mathrm{Cu}$ removal may be more related to biochar surface functional groups, which could promote complex formation and enhancing ability to bind the metals (Xu and Fang, 2015). The ash content of biochar may also influence the sorption behavior of biochar, encourage metal precipitation and immobilization (Lahori et al., 2017). Cárdenas-Aguiar et al. (2017) found a significant reduction in the mobile form of $\mathrm{Cu}$ in the soils treated by $10 \mathrm{wt} \%$ of biochar. It is clear that $\mathrm{Cu}^{2+}$ adsorption capacity of biochar decreased with increasing pyrolysis temperature, high rate addition of RHB and the inorganic pollutant $\mathrm{Cu}^{2+}$ could be more adsorbed on the surface of the rice straw biochar produced at lower temperatures as in agreement with results of Jiang et al. (2015). Also, application of RH biochar was more effective in increasing $\mathrm{N}$ concentration in both peanut shoot and grains. It was observed that addition of 3 ton RHB fed ${ }^{-1}$ increased the N concentration by 209 and $155 \%$ 
Citation: Sahar Mohamed Ismail; Sherine Shehata Marid and Doaa Taha Eissa Monitoring and Remediation of Environmental Aspects of Fe-rich Soils of Bahariya Oases and their Effects on peanut Quality Australian Journal of Basic and Applied Sciences, 13(9): 66-91. DOI: 10.22587/ajbas.2019.13.9.7

compared with control $(0.63$ and $0.45 \%)$ in peanut shoot and grains, respectively (Table 11). The results in Table (11) reveal also that application of RH biochar increased the P-concentration in peanut shoot and grains by 40; 100 and $130 \%$ in peanut shoot and 13.33; 40.00 and $66.66 \%$ in peanut grains owing to apply of the RH biochar at rates 1; 2 and 3 ton fed $^{-1}$, respectively. Biochar inhibited nitrogen and phosphorus leaching by providing a reactive surface in which nitrogen and phosphorus ions remain in the soil microbial and exchange sites, both of which regulate crop nitrogen and phosphorus availability, thus rice husk is good effect on serving nutrient (Gul, et al., 2016). Potassium concentration was affected by maximum RHB-application ( 3 ton fed $\left.{ }^{-1}\right)$ and $\mathrm{K}^{-}$ increased significantly in both shoots and grains by 9.88 and $0.95 \%$, respectively. This result was in agreement with those of Steiner et al. (2007) who found that RH biochar application increased N, P and K of groundnut plants on alkaline calcareous soil. The concentrations of metals in plant shoot and grains showed different results due to the different RHB rates. In general, soil phyto-available metal pools following RHB amendment rates was decreased for all heavy metals in peanut shoot and grains (Table 11). Mean concentrations of $\mathrm{Fe}, \mathrm{Mn}, \mathrm{Zn}, \mathrm{Cu}, \mathrm{Ni}$ and $\mathrm{Cd}$ in peanut shoots after addition of highest rate of RHB (3 ton fe $\left.\mathrm{d}^{-1}\right)$ were 762, 56, 51.2, 26.1, 0.98 and $0.21 \mathrm{mg} \mathrm{kg}^{-1}$, respectively (Table 11). Compared with control and lower RHB rates, concentration of Fe in plant shoots in all RHB rates $(\mathrm{p} \leq 0.05)$ decreased significantly (Table 11). Plant uptake and accumulation of $\mathrm{Fe}, \mathrm{Mn}, \mathrm{Zn}, \mathrm{Cu}$, Ni and $\mathrm{Cd}$ in shoots decreased by 36.71; 47.66; 37.56; 59; 69.18 and 80.37 \%, respectively, due to the application of the highest rate of RHB. Likewise, $\mathrm{Fe}, \mathrm{Mn}, \mathrm{Zn}, \mathrm{Cu}, \mathrm{Ni}$ and $\mathrm{Cd}$ concentrations in peanut grains significantly $(\mathrm{p} \leq 0.05)$ decreased by $68.42 ; 49.69 ; 28.93 ; 77.56 ; 70.99$ and 92.19 , respectively. This reduction in metal accumulation by both peanut shoot and grains is attributed principally to increase in $\mathrm{pH}$ which induced a decrease in their phyto-availability following each RHB application. In agreement with these results, Zheng et al. (2012) recorded an increase in pH, while RHB was applied as an

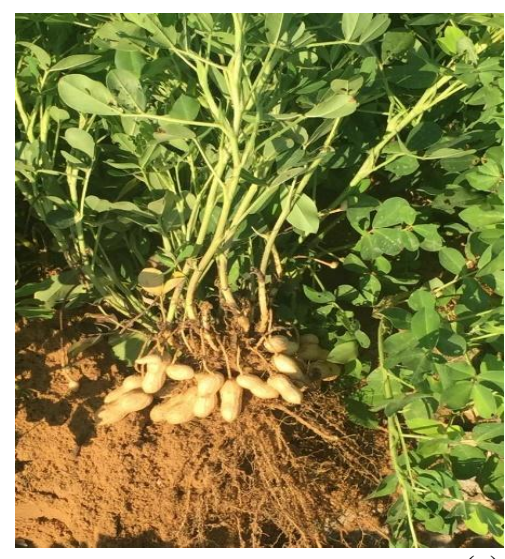

(a)

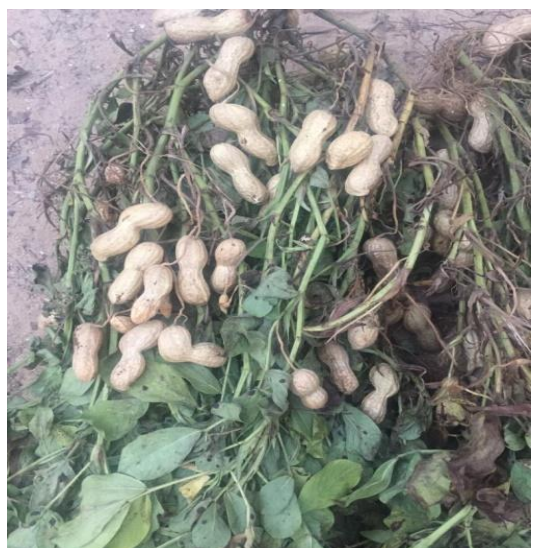

(b)

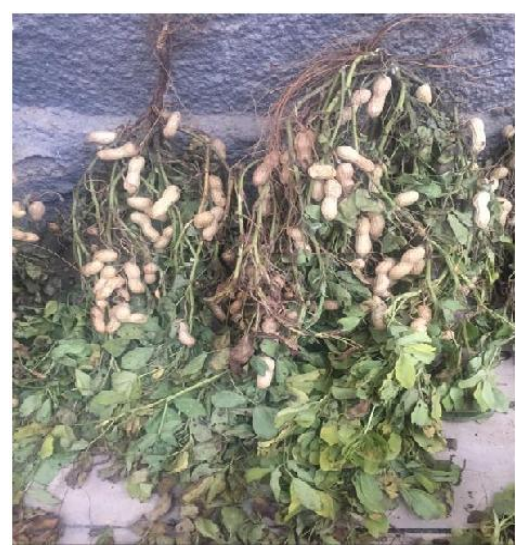

(c)

Fig. (17). Fe (III) immobilization as affected by the applied soil RH biochar levels compared with control. Peanut pods without Fe (III)-red pigment at highest biochar addition, 3 ton $\mathrm{fed}^{-1}$ (a). Peanut pods with slightly Fe (III)-red pigment at biochar addition 1 ton fed ${ }^{-1}$ (b). Peanut pods without biochar additions with Fe (III)-red pigment as control (c).

amendment, which caused immobilization of heavy metals in the soil and subsequently reduced translocation of metals in the tissues of the plant. On the other hand, the peanut productivity per fedden increased with highest biochar additions compared to control and lower biochar rates. The peanut productivity reached 1.83 ton due to application of the biocharat a rate of 3 ton fed ${ }^{-1}$, while the corresponding productivity of the control was 0.72 ton $\mathrm{fed}^{-1}$ with increasing percentages of $154.16 \%$. Also, the size of pod increased (i.e. pod quality) from $42 \mathrm{pod} / 100 \mathrm{~g}$ as control to $35 \mathrm{pod} / 100 \mathrm{~g}$ at highest biochar addition $\left(3\right.$ ton fed $\left.^{-1}\right)$, which related to increase of pod densities than control treatment (Table 11).

\subsubsection{K-humate treatment}

Data in Table (9) indicate that the addition of different K-kumate rates slightly reduced $(\mathrm{P} \leq 0.05)$ soil $\mathrm{pH}$ and soil salinity from 7.5 to 7.06 and from 5.32 to $4.31 \mathrm{dS} \mathrm{m}^{-1}$, respectively. The corresponding relative decreases were 5.86 and $18.98 \%$ as compared to the control, respectively. Khademi et al. (2009) concluded that when organic acids are added to solution they bind cations (e.g Ca) causing the release of $\mathrm{H}^{+}$from organic acids, which consequently lowers solution $\mathrm{pH}$. One of the most important properties of humic acids is its large buffering capacity in a wide $\mathrm{pH}$ range, which arises essentially from the dissociation of acidic functional groups of which they are particularly rich (Campitelli et al., 2005). SAR values were significantly $(\mathrm{P} \leq 0.05)$ reduced, due to all K-humate treatments compared with control (Table 9) ranging from greatest reduction value 51.59 when K-humate was applied at a rate of $50 \mathrm{~kg} \mathrm{fed}^{-1}$ to least reduction value $60.51 \%$ when K-humate was applied at a rate of $150 \mathrm{~kg}$ fed Exchangeable sodium percentage (ESP) was significantly $(\mathrm{P} \leq 0.05)$ decreased from 18.3 (control) to 8.3 upon application of the highest rate of K-humate as shown in Table 9. The reduction percentages were 46.44, 49.72 and $54.64 \%$ due to application of 50, 100 and $150 \mathrm{~kg} \mathrm{~K}$-humate $\mathrm{fed}^{-1}$, respectively. One of the most striking characteristics of humic substances in soils and other environments is their ability to interact with metal ions and soil minerals to form complexes of variable properties and increasing chemical stability (Filip \& Bielek, 2002). Our findings revealed that all K-humate applications had a highly significant effect on increasing extractable metals remained in soil after peanut harvesting $(\mathrm{P} \leq 0.05)$ compared to control as shown in Table 10 . 


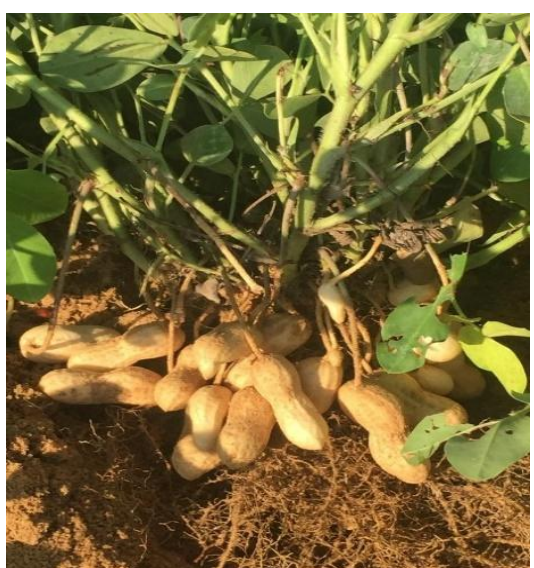

(a)

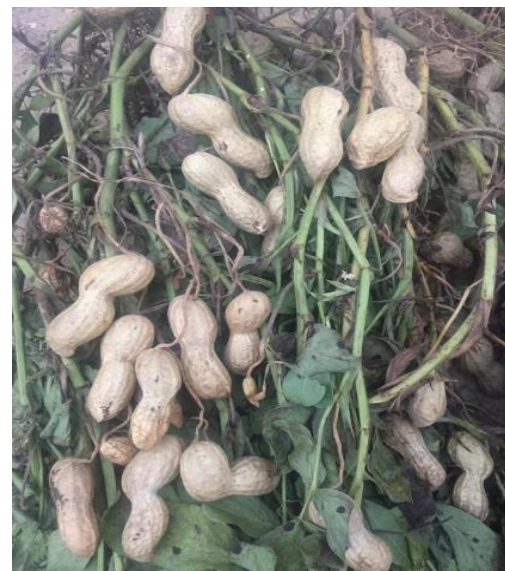

(b)

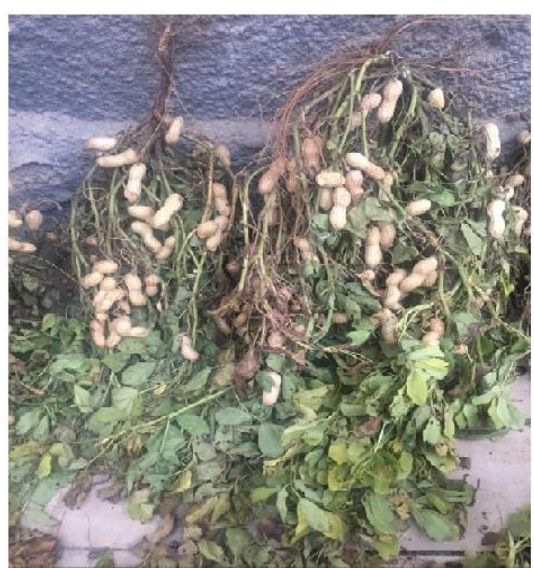

(c)

Fig. (18). Fe (III) immobilization as affected by the applied soil K-humate (KH) levels compared with control. Peanut pods without Fe (III)-red pigment at highest $\mathrm{KH}$ addition, $150 \mathrm{~kg} \mathrm{fed}^{-1}$ (a). Peanut pods with slightly Fe (III)-red pigment at $\mathrm{KH}$ addition $50 \mathrm{~kg}^{-1}$ fed (b). Peanut pods without $\mathrm{KH}$ additions with $\mathrm{Fe}$ (III)-pigment as control (c).

This can be attributed to the improving of metal supply potentials of sandy soils (Suganya and Sivasamy, 2006). Mean increasing of the extractable-metals $\mathrm{Fe}, \mathrm{Mn}, \mathrm{Zn}, \mathrm{Cu}$ and $\mathrm{Ni}$ after peanut harvest was greatest $(54.08 ; 38.18 ; 8.80 ; 12.38$ and $12.34 \%$, respectively) upon application of the highest rate of K-humate $\left(150 \mathrm{~kg} \mathrm{fed}^{-1}\right)$ and least $(28.30 ; 1.11 ; 5.49 ; 2.06$ and $1.64 \%$, respectively) upon application of the lowest rate of $\mathrm{K}$-humate $\left(50 \mathrm{~kg} \mathrm{fed}^{-1}\right)$. On the other hand, extractable-Cd was significantly $(\mathrm{P} \leq 0.05)$ decreased with higher K-humate additions, probably due to formation more stable complexes. Humic substances also promote heavy metal sorption to soil minerals like $\mathrm{Cu}, \mathrm{Zn}, \mathrm{Ni}$ and $\mathrm{Cd}$. Applications of $\mathrm{KH}$ had a significant effect on mineral elements uptake in peanut (Table 11). When compared with the control treatment, the uptake values of elements were higher. Application of KH affected the uptake of NPK which were statistically $(\mathrm{P} \leq 0.05)$ significant. The highest NPK concentrations in peanut shoot and grains were obtained with a dose of $150 \mathrm{~kg} \mathrm{KH}^{-1} \mathrm{ed}^{-1}$. However, the amounts of $\mathrm{Fe}, \mathrm{Mn}, \mathrm{Zn}$ and $\mathrm{Cu}$ in peanut shoot and grains (except $\mathrm{Ni}$ and $\mathrm{Cd}$ ) were found higher than in the control by all $\mathrm{KH}$ treatments, especially at the highest dose of KH. David et al. (1994) reported promoted growth and more nutrient uptake by plants due to the addition of humic substances and better-developed root systems. In addition, stimulation of ions uptake in the use of humic materials has resulted many researchers to suggest that these materials have an impact on membrane permeability (Zientara 1983). This relates to the surface activity of humic substances arising from the existence of both hydrophilic and hydrophobic sites. Therefore, the humic substances may interact with, and react as nutrient carriers through the phospholipid of the cell membranes. According to many investigators, humic substances may increase the uptake of some nutrients and decrease the uptake of toxic elements (Liu 1998). On the other

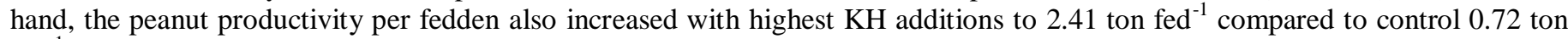
$\mathrm{fed}^{-1}$. Also, the size of pod increased (i.e. pod quality) from $42 \mathrm{pod} / 100 \mathrm{~g}$ as control to $36 \mathrm{pod} / 100 \mathrm{~g}$ at highest $\mathrm{KH}$ addition ( $150 \mathrm{~kg}$ $\mathrm{KH} \mathrm{fed}{ }^{-1}$ ), which related to increase of pod densities and degree of fullness than control treatment (Table 11).

\subsubsection{Sugar industry waste treatment (bio-sorbent)}

Any kind of plant, animal, and microbial biomass and their derivatives; plant, industrial and agricultural wastes; and byproducts discharged from various industries can be employed as bio-sorbents (Macek and Mackova, 2011). From Table 4 and Fig. 13, it was found that the $\mathrm{pH}$ of sugar beet industry waste was 8.39 . Therefore this industrial waste has alkaline nature which is dependent on processing technique. Oxides and hydroxides of potassium, sodium, magnesium and calcium probably caused this high pH (Hong et al., 2000). The total ash of sugar beet was $75.25 \%$ which indicates the high mineral contents of sample. The C/N ratio was 5.60 in the sugar beet filter cake. Suresh and Reddy (2011) mentioned that the organic carbon present in the SIW sample consisted mainly of cellulose, hemicellulose, lignin, protein, sucrose, wax, etc. The mechanism of bio-sorption is a complex process which involves the binding of sorbate onto the bio-sorbent. The absence of Fe-red pigment from peanut pods as shown in Fig. 19a was observed in our study at the highest addition of $600 \mathrm{~kg} \mathrm{SIW} \mathrm{fed}^{-1}$ compared to the lower dose (Fig.19b) and control (Fig. 19c). This may ascribed to the formation of a complex by the association of two or more species. Wu et al. (2012) indicated that the mononuclear (mono-dentate) complexes are formed between the Fe ion and the ligands in which the Fe atom occupies the central position or poly-nuclear (multi-denate) complex that formed by more than one metal ion in the center and the metal atom may carry a positive, negative, or neutral charge depending on the number of binding ligands involved. The complex formation to the mono-dentate ligand is more preferable than multi-dentate because the latter contains multiple ligands which may lead to multiple species binding. The Fe ion interacts with the ligands by covalent bonds. Beside complexion, ion exchange can occur that is an important concept in bio-sorption which involves the exchange of binary metal ions during bio-sorption with the counter-ions present on the surface of the bio-sorbent. Most of the purification process works on the mechanism of ion exchange. On the surface, three functional groups of cation exchange were recognized: phosphate, carboxyl, and hydroxyl groups (Chojnacka et al., 2005). Since the process of bio-sorption relies on the number and availability of functional groups on the surface of the bio-sorbent, modification by changing the surface characteristics can greatly influence the capacity of bio-sorbent used for the removal of metal ions (Gupta et al., 2002). 
Citation: Sahar Mohamed Ismail; Sherine Shehata Marid and Doaa Taha Eissa Monitoring and Remediation of Environmental Aspects of Fe-rich Soils of Bahariya Oases and their Effects on peanut Quality Australian Journal of Basic and Applied Sciences, 13(9): 66-91. DOI: 10.22587/ajbas.2019.13.9.7

Table (9). Effect of different organic amendments on some chemical characteristics of post-harvest peanut soil irrigated by with well water pivot.

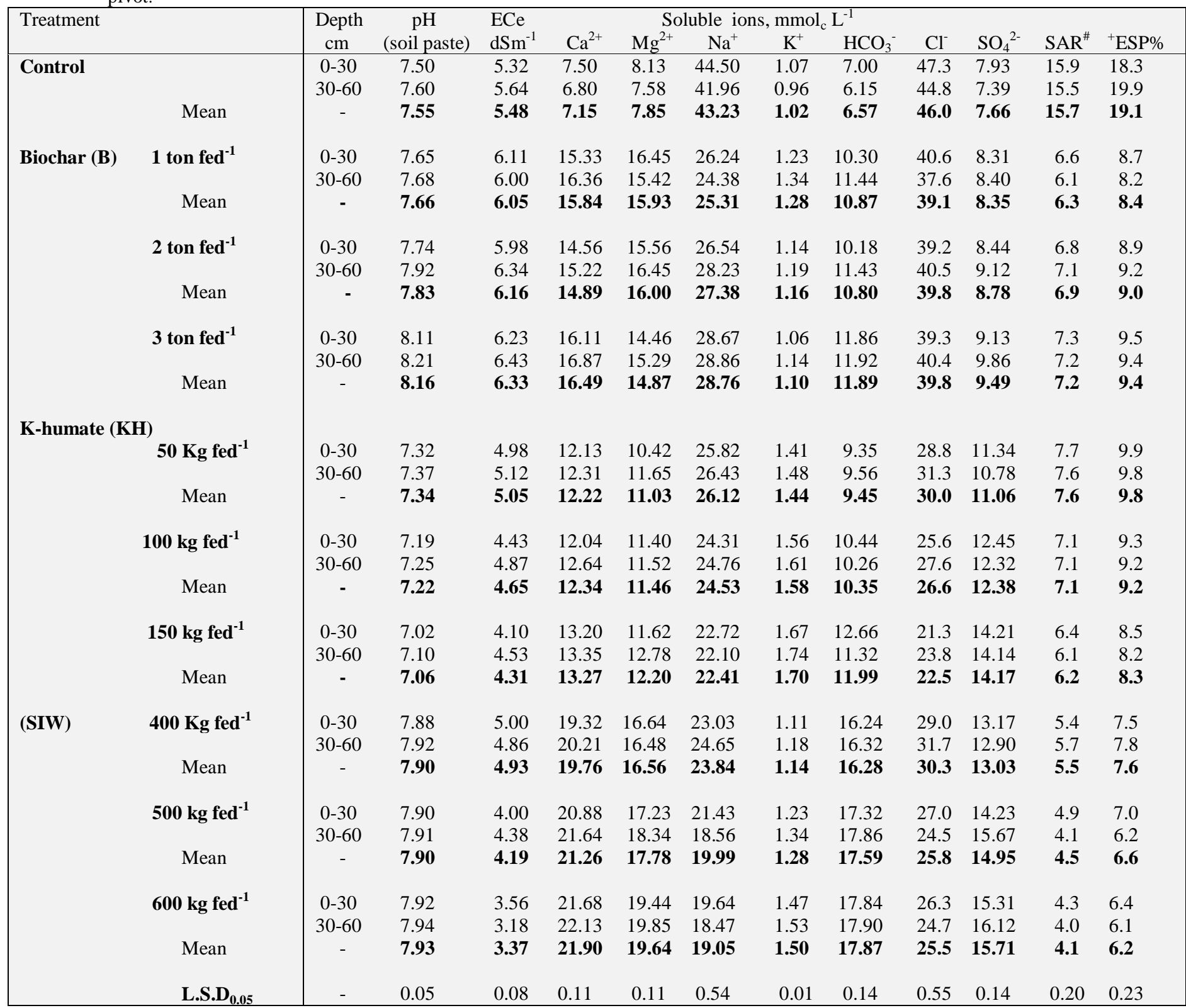

*SAR: Sodium Adsorption Ratio: $\left.\mathrm{Na}^{+} / \sqrt{(\mathrm{Ca}}+\mathrm{Mg}\right) / 2 \quad{ }^{+}$ESP: calculated by equation $1.95+1.03 \mathrm{SAR}(\mathrm{Mohsen}, 2009)$.

Hence, all these explanations have led to the removal of the Fe-red pigment by the application of the highest dose of SIW. As observed in Table 9, at harvest, the $\mathrm{pH}$ of the soil is found to be alkaline in nature (7.55), and it becomes more alkaline with an increase in the concentration of SIW (7.93) by increasing rate of SIW to $5.03 \%$. Oxides and hydroxides of potassium, sodium, magnesium and calcium were formed by SIW caused this high pH (Hong et al., 2000). SIW had a highly significant $(\mathrm{P} \leq 0.05)$ effect on decreasing salinity of the soil after harvesting of peanut plants as shown in Table 9 . Data show that the mean values of ECe were decreased by about 10.03, 23.54 and $38.50 \%$ with the application of 400,500 and $600 \mathrm{~kg} \mathrm{SIW} \mathrm{fed}^{-1}$, respectively. SIW amendment was relatively effective in reducing the EC values. This may be due to the fact that the exchanger phase acts as a sink for the dissolved Ca-ions. These findings are in the same line with those acquired by Abdurrahman et al. (2004). Data presented in Table 9 showed that SAR values were significantly $(\mathrm{P} \leq 0.05)$ decreased with increasing SIW application rates up to $600 \mathrm{~kg} \mathrm{fed}^{-1}$, comparing with the control after peanut harvest where SAR values were decreased by $64.96,71.33$ and $73.88 \%$ with application of 400, 500 and $600 \mathrm{~kg} \mathrm{SIW} \mathrm{fed}^{-1}$, respectively. The same trend was observed with ESP, where its values were significantly decreased by $60.21,49.74$ and $67.54 \%$ with application of 400, 500 and $600 \mathrm{~kg}^{\text {SIW fed }}{ }^{-1}$, respectively. This may be ascribed to the dominance of soluble $\mathrm{Ca}^{2+}$ on the exchange complex. These results are in agreement with those of Mansour et al. (2011). Table 9 outlined that at highest addition of SIW caused highest pH compared to the lower additions and control, maybe due to existence lower number of $\mathrm{H}^{+}$ions, and the number of active sites in the functional groups is free and exposed (negative charge) resulting in enhanced bio-sorption by attracting positive-charged metal ions and metal might begin to precipitate and form hydroxides and as a consequence hinder the bio-sorption process (Joseph, 2015). 
Citation: Sahar Mohamed Ismail; Sherine Shehata Marid and Doaa Taha Eissa Monitoring and Remediation of Environmental Aspects of Fe-rich Soils of Bahariya Oases and their Effects on peanut Quality Australian Journal of Basic and Applied Sciences, 13(9): 66-91. DOI: 10.22587/ajbas.2019.13.9.7

Table (10). Effect of different organic amendments on soil DTPA-extractable heavy metal contents of post-harvest peanut soil irrigated by well water pivot.

\begin{tabular}{|c|c|c|c|c|c|c|c|c|}
\hline \multirow{2}{*}{\multicolumn{2}{|c|}{ Treatment }} & \multirow{2}{*}{$\begin{array}{l}\text { Depth } \\
\text { (cm) }\end{array}$} & \multicolumn{4}{|c|}{ Heavy metals, $\mathrm{mg} \mathrm{kg}^{-1}$} & \multirow[b]{2}{*}{$\mathrm{Ni}$} & \multirow[b]{2}{*}{$\mathrm{Cd}$} \\
\hline & & & $\mathrm{Fe}$ & $\mathrm{Mn}$ & $\mathrm{Zn}$ & $\mathrm{Cu}$ & & \\
\hline \multirow{2}{*}{\multicolumn{2}{|c|}{ Control }} & $0-30$ & 13.60 & 24.94 & 18.75 & 6.50 & 2.71 & 1.16 \\
\hline & & $30-60$ & 11.84 & 45.36 & 13.27 & 6.11 & 2.15 & 0.99 \\
\hline \multirow{3}{*}{\multicolumn{2}{|c|}{ Biochar (B) }} & - & 12.72 & 35.15 & 16.01 & 6.30 & 2.43 & 1.07 \\
\hline & & $0-30$ & 10.14 & 20.75 & 14.82 & 6.35 & 1.92 & 0.85 \\
\hline & & $30-60$ & 9.24 & 39.14 & 12.85 & 6.22 & 1.95 & 0.68 \\
\hline \multicolumn{2}{|r|}{ Mean } & - & 9.69 & 29.94 & 13.83 & 6.28 & 1.93 & 0.76 \\
\hline \multirow{2}{*}{\multicolumn{2}{|c|}{2 ton fed $^{-1}$}} & $0-\overline{30}$ & 8.42 & 17.72 & 13.31 & 6.25 & 1.72 & 0.72 \\
\hline & & $30-60$ & 8.76 & 32.16 & 11.10 & 6.17 & 1.76 & 0.56 \\
\hline \multicolumn{2}{|r|}{ Mean } & - & 8.59 & 24.44 & 12.20 & 6.21 & 1.74 & 0.64 \\
\hline \multirow{2}{*}{\multicolumn{2}{|c|}{3 ton fed ${ }^{-1}$}} & $0-30$ & 6.33 & 14.80 & 10.60 & 6.21 & 1.44 & 0.53 \\
\hline & & $30-60$ & 6.58 & 26.94 & 11.14 & 6.12 & 1.53 & 0.42 \\
\hline \multicolumn{2}{|r|}{ Mean } & - & 6.45 & 20.87 & 10.87 & 6.16 & 1.48 & 0.47 \\
\hline \multicolumn{2}{|c|}{ K-humate (KH) } & $0-30$ & 14.90 & 27.17 & 17.36 & 6.32 & 2.28 & 0.56 \\
\hline \multirow{2}{*}{\multicolumn{2}{|c|}{$50 \mathrm{Kg} \mathrm{fed}^{-1}$}} & $30-60$ & 17.75 & 43.92 & 16.42 & 6.54 & 2.50 & 0.58 \\
\hline & & - & 16.32 & 35.54 & 16.89 & 6.43 & 2.39 & 0.57 \\
\hline & & $0-30$ & 17.45 & 34.23 & 16.65 & 6.88 & 2.46 & 0.73 \\
\hline \multirow{2}{*}{\multicolumn{2}{|c|}{$100 \mathrm{~kg} \mathrm{fed}^{-1}$}} & $30-60$ & 19.81 & 47.92 & 17.12 & 6.91 & 264 & 0.76 \\
\hline & & - & 18.63 & 41.07 & 16.88 & 6.89 & 2.55 & 0.74 \\
\hline \multirow[b]{4}{*}{ (SIW) } & Mean & $0-30$ & 18.46 & 45.00 & 18.11 & 6.95 & 2.68 & 0.81 \\
\hline & $150 \mathrm{~kg} \mathrm{fed}^{-1}$ & $30-60$ & 20.74 & 52.14 & 16.74 & 7.22 & 2.78 & 0.95 \\
\hline & Mean & - & 19.60 & 48.57 & 17.42 & 7.08 & 2.73 & 0.88 \\
\hline & $400 \mathrm{Kg} \mathrm{fed}^{-1}$ & $0-30$ & 8.61 & 19.82 & 15.50 & 4.92 & 1.92 & 0.86 \\
\hline & & $30-60$ & 8.82 & 34.75 & 12.20 & 4.63 & 1.71 & 0.63 \\
\hline & Mean & - & 8.71 & 27.28 & 13.85 & 4.77 & 1.81 & 0.74 \\
\hline \multirow{2}{*}{\multicolumn{2}{|c|}{$500 \mathrm{~kg} \mathrm{fed}^{-1}$}} & $0-30$ & 7.69 & 17.42 & 13.61 & 4.04 & 1.31 & 0.50 \\
\hline & & $30-60$ & 7.31 & 14.41 & 11.84 & 3.89 & 1.12 & 0.37 \\
\hline \multirow{3}{*}{\multicolumn{2}{|c|}{$600 \mathrm{~kg} \mathrm{fed}^{-1}$}} & - & 7.50 & 15.91 & 12.72 & 3.96 & 1.21 & 0.43 \\
\hline & & $0-30$ & 7.23 & 14.33 & 13.28 & 3.84 & 1.03 & 0.36 \\
\hline & & $30-60$ & 7.04 & 12.42 & 10.65 & 3.12 & 0.88 & 0.22 \\
\hline & Mean & - & 7.13 & 13.37 & 11.96 & 3.48 & 0.95 & 0.29 \\
\hline & L.S.D $0_{0.05}$ & & 0.14 & 0.28 & 0.11 & 0.06 & 0.05 & 0.06 \\
\hline
\end{tabular}

Table (11). Pod yields, weight of 100 pods, NPK and heavy metals concentrations of peanut shoot and grains cultivated in Bahariya Oasis soil as affected by different $\mathrm{Fe}$-inorganic amendments and irrigated by well water pivot.

\begin{tabular}{|c|c|c|c|c|c|c|c|c|c|c|c|c|c|}
\hline Treatment & & $\begin{array}{l}\text { Pods yield } \\
\left(\mathrm{kg} / 100 \mathrm{~m}^{2}\right)\end{array}$ & $\begin{array}{l}\text { weight of } 100 \\
\text { pods }(\mathrm{g})\end{array}$ & $\begin{array}{l}\text { Part of } \\
\text { plant }\end{array}$ & $\begin{array}{c}\mathrm{N} \\
(\%)\end{array}$ & $\begin{array}{c}\mathrm{P} \\
(\%)\end{array}$ & $\begin{array}{c}\mathrm{K} \\
(\%)\end{array}$ & $\begin{array}{c}\mathrm{Fe} \\
\left(\mathrm{mg} \mathrm{kg}^{-1}\right)\end{array}$ & $\begin{array}{c}\mathrm{Mn} \\
\left(\mathrm{mg} \mathrm{kg}^{-1}\right)\end{array}$ & $\begin{array}{c}\mathrm{Zn} \\
\left(\mathrm{mg} \mathrm{kg}^{-1}\right)\end{array}$ & $\begin{array}{c}\mathrm{Cu} \\
\left(\mathrm{mg} \mathrm{kg}^{-1}\right)\end{array}$ & $\begin{array}{c}\mathrm{Ni} \\
\left(\mathrm{mg} \mathrm{kg}^{-1}\right)\end{array}$ & $\begin{array}{c}\mathrm{Cd} \\
\left(\mathrm{mg} \mathrm{kg}^{-1}\right)\end{array}$ \\
\hline \multirow{2}{*}{\multicolumn{2}{|c|}{ Control }} & 17.23 & 265.3 & Shoot & 0.63 & 0.10 & 1.04 & 1204 & 107 & 82.0 & 63.7 & 3.18 & 1.07 \\
\hline & & & & Grains & 0.45 & 0.15 & 0.45 & 833 & 82.1 & 51.5 & 56.6 & 1.31 & 1.41 \\
\hline \multirow[t]{6}{*}{ Biochar (B) } & 1 ton fed $^{-1}$ & 22.43 & 245.6 & Shoot & 1.63 & 0.14 & 2.36 & 1092 & 88 & 70.5 & 48.5 & 2.25 & 0.86 \\
\hline & & & & Grains & 0.86 & 0.17 & 0.77 & 614 & 62.3 & 46.2 & 25.2 & 0.89 & 0.52 \\
\hline & 2 ton fed $^{-1}$ & 34.19 & 235.9 & Shoot & 1.72 & 0.20 & 2.83 & 986 & 79 & 62.8 & 37.4 & 1.61 & 0.54 \\
\hline & & & & Grains & 0.98 & 0.12 & 1.03 & 436 & 58.3 & 40.4 & 18.9 & 0.64 & 0.41 \\
\hline & 3 ton ed $^{-1}$ & 43.62 & 222.5 & Shoot & 1.95 & 0.23 & 3.12 & 762 & 56 & 51.2 & 26.1 & 0.98 & 0.21 \\
\hline & & & & Grains & 1.15 & 0.25 & 1.36 & 263 & 41.3 & 36.6 & 12.7 & 0.38 & 0.11 \\
\hline \multicolumn{14}{|c|}{ K-humate (KH) } \\
\hline \multirow{14}{*}{ (SIW) } & $50 \mathrm{Kg} \mathrm{fed}^{-1}$ & 32.53 & 250.4 & Shoot & 2.26 & 0.43 & 2.46 & 2315 & 159 & 96.5 & 64.3 & 1.64 & 0.96 \\
\hline & & & & Grains & 2.38 & 0.25 & 0.36 & 879 & 85.3 & 56.4 & 58.8 & 0.66 & 0.72 \\
\hline & $100 \mathrm{~kg} \mathrm{fed}^{-1}$ & 48.21 & 242.2 & Shoot & 2.44 & 0.58 & 3.52 & 2661 & 197 & 111 & 88.1 & 1.69 & 0.86 \\
\hline & & & & Grains & 2.53 & 0.32 & 0.58 & 969 & 92.7 & 62.5 & 61.3 & 0.74 & 0.65 \\
\hline & $150 \mathrm{~kg} \mathrm{fed}^{-1}$ & 57.34 & 230.4 & Shoot & 2.89 & 0.72 & 5.03 & 2948 & 254 & 146 & 96.7 & 1.83 & 0.68 \\
\hline & & & & Grains & 3.21 & 0.50 & 0.76 & 998 & 98.8 & 89.4 & 73.2 & 0.82 & 0.51 \\
\hline & $400 \mathrm{Kg} \mathrm{fed}^{-1}$ & 38.37 & 270.2 & Shoot & 1.78 & 0.52 & 1.26 & 1352 & 101 & 83.2 & 57.4 & 1.07 & 0.94 \\
\hline & & & & Grains & 2.15 & 0.18 & 0.22 & 285 & 52.9 & 52.4 & 38.5 & 0.42 & 0.45 \\
\hline & $500 \mathrm{~kg} \mathrm{fed}^{-1}$ & 50.14 & 287.1 & Shoot & 1.83 & 0.64 & 1.42 & 1286 & 86 & 76.9 & 46.8 & 0.90 & 0.71 \\
\hline & & & & Grains & 2.23 & 0.25 & 0.26 & 238 & 43.7 & 43.3 & 31.7 & 0.33 & 0.30 \\
\hline & $600 \mathrm{~kg} \mathrm{fed}^{-1}$ & 64.78 & 332.7 & Shoot & 1.94 & 0.72 & 1.76 & 1081 & 78 & 63.5 & 34.8 & 0.78 & 0.58 \\
\hline & & & & Grains & 2.42 & 0.31 & 0.38 & 189 & 36.4 & 32.8 & 19.8 & 0.24 & 0.23 \\
\hline & L.S.D 0.05 & 3.84 & 3.86 & Shoot & 0.08 & 0.006 & 0.07 & 16.5 & 1.33 & 0.68 & 0.64 & 0.06 & 0.08 \\
\hline & & & & Grains & 0.03 & 0.004 & 0.006 & 6.53 & 1.03 & 0.72 & 0.70 & 0.03 & 0.003 \\
\hline
\end{tabular}




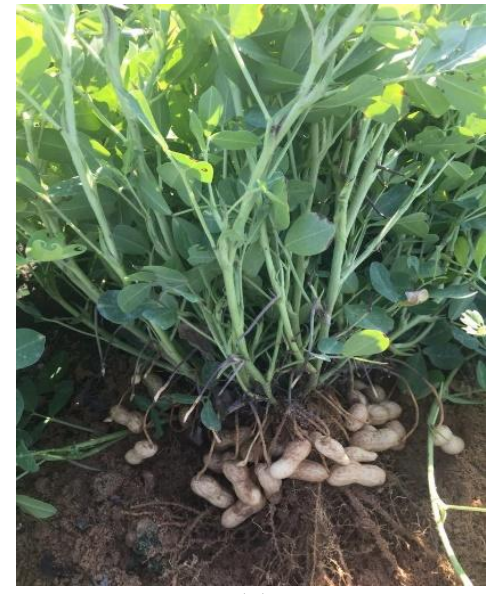

(a)

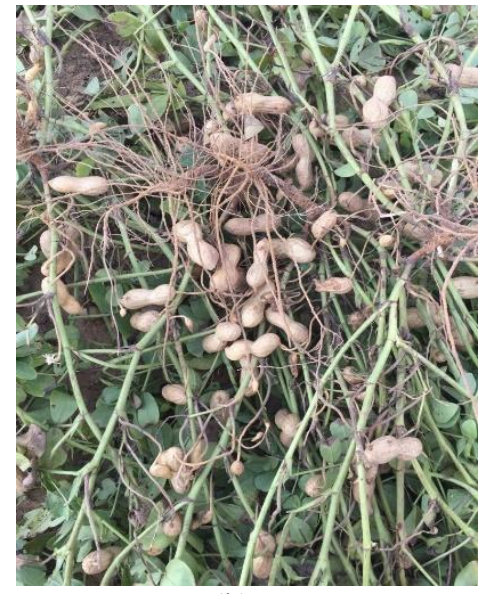

(b)

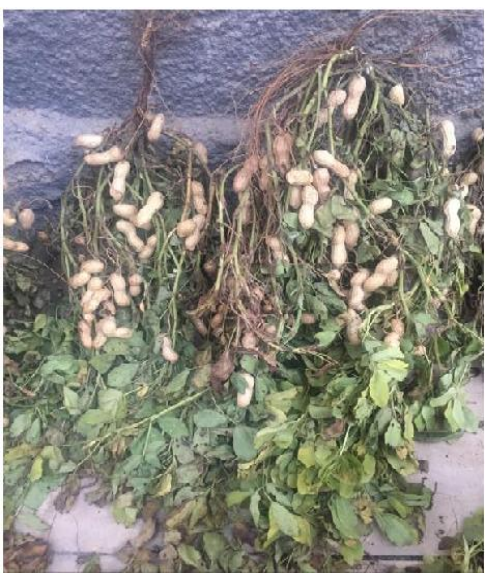

(c)

Fig. (19). Fe (III) immobilization as affected by the applied soil SIW levels compared with control. Peanut pods without Fe (III) - red pigment at highest SIW addition, $600 \mathrm{~kg} \mathrm{fed}^{-1}$ (a). Peanut pods with slightly Fe (III)-red pigment at $\mathrm{KH}$ addition $400 \mathrm{~kg}^{-1}$ fed (b). Peanut pods without SIW additions with Fe (III)-pigment as control (c).

Therefore, the extractable heavy metals $\mathrm{Fe}, \mathrm{Mn}, \mathrm{Zn}, \mathrm{Cu}, \mathrm{Ni}$ and $\mathrm{Cd}$ decreased as soil $\mathrm{pH}$ increased, where their values were significantly decreased by 43.94, 61.96, 25.29, 44.76, 60.90 and $72.89 \%$, respectively at highest rate of SIW, $600 \mathrm{~kg}$ fed $\mathrm{d}^{-1}$ (Table 10) compared to the lower concentrations and control. Table 11 reveals that SIW doses significantly (P $\leq 0.05)$ increased pods yield, 100-seeds weight and NPK levels. The highest SIW dose resulted in highest increase of pods yield per fedden $(2.72$ ton $\left.\mathrm{fed}^{-1}\right), 100$-pods weight $(332.7 \mathrm{~g})$ compared to the control $\left(0.72\right.$ ton fed ${ }^{-1}$ and $222.5 \mathrm{~g}$, respectively) and increased NPK contents by $1.78,0.52,1.26$, respectively in shoots and $2.15,0.18,0.22 \%$, respectively in grains compared to control $(0.63,0.10$, 1.04 in shoots and $0.45,0.15,0.45 \%$ in grains, respectively). Recently, it has been acknowledged that by-products of sugar industry should be regarded as helpful materials. These by-products are of excellent importance due to their elevated organic matter, N, P and K contents and probably other elements (Yassen et al. 2002). Therefore, some of these sugar industry byproducts may represent an important source of nutrients, and thereby could be used as a substitute for chemical and organic fertilizers (Gemtos et al. 1999). On the other hand, the size of pod increased (i.e. pod quality) from 42 pod/100g as control to 32 pod $/ 100 \mathrm{~g}$ at highest SIW addition $\left(600 \mathrm{~kg} \mathrm{SIW} \mathrm{fed}^{-1}\right)$, which related to increasing of pod densities and degree of fullness than control treatment (Table 11). The $\mathrm{Fe}, \mathrm{Mn}, \mathrm{Zn}, \mathrm{Cu}, \mathrm{Ni}$ and $\mathrm{Cd}$ concentrations in peanut shoot were lower than corresponding ones of the control in all SIW treatments and the lowest values were obtained when highest SIW dose was applied $\left(600 \mathrm{~kg}^{-1}\right)$, where $\mathrm{Fe}, \mathrm{Mn}, \mathrm{Zn}, \mathrm{Cu}, \mathrm{Ni}$ and $\mathrm{Cd}$ concentrations in peanut shoot were $1081,78,63.5,34.8,0.78$ and $0.58 \mathrm{mg} \mathrm{kg}-^{1}$, respectively and their concentrations in peanut seeds were $189,36.4,32.8,19.8,0.24$ and $0.23 \mathrm{mg} \mathrm{kg}^{-1}$, respectively when the highest rate of SIW was applied compared with the control (Table 11).

\section{CONCLUSION}

The main goal of in situ soil remediation techniques is to reduce mobility, bioavailability and toxicity of the Fe that contaminate soil in Bahariya Oases and remove Fe-red pigment from peanut pods based on use of inorganic and organic amendments. This soil contains a mixture of goethite and hematite minerals and tiny quantities of hematite and gangue minerals represented mainly by quartz, in addition to small quantities of halite and illite. Results from these case study revealed that the application of soil amendments, such as gypsum, phosphogypsum, sulfur, rice husk biochar, and sugar beet industry waste to Fecontaminated sites, reduced the phyto-availability of $\mathrm{Fe}$ and other metals and removed Fe-red color when these amendments were used at their highest doses: $600 \mathrm{~kg} / \mathrm{fed}, 600 \mathrm{~kg} / \mathrm{fed}, 200 \mathrm{~kg} / \mathrm{fed}, 3 \mathrm{ton} / \mathrm{fed}$ and $600 \mathrm{~kg} / \mathrm{fed}$, respectively, through binding their functional groups with $\mathrm{Fe}$ and formation of ligand-Fe. The highest addition of sugar beet industry waste had pod yields and fully absence of Fe-red color from peanut pods. Since bioavailability is the main point for remediation technology, immobilization may be a preferred option. While K-humate additions had a slightly Fe-red color on peanut pods even at its highest dose, yet, all the other inorganic and organic amendments had a highly significant effect on improving peanut pod yield quantities, pod quality as well as macro-nutrients. Micronutrient concentrations were decreased as result of metal-stabilization in soil as compared to control treatment. Globally there is a tendency to create simple, fast, inexpensive and efficient natural materials for adsorption of heavy metals. Nowadays, there is an increasing trend for using natural material for removal of pollutants from contaminated soil. Phosphogypsum, gypsum, rice husk biochar and sugar beet industry waste, as low-cost inorganic and organic sorbent materials, have been proven as a promising material for the removal of metals ( $\mathrm{Fe}, \mathrm{Zn}, \mathrm{Cu}, \mathrm{Cd}$ and $\mathrm{Ni}$ ) from contaminated soil. 
Citation: Sahar Mohamed Ismail; Sherine Shehata Marid and Doaa Taha Eissa Monitoring and Remediation of Environmental Aspects of Fe-rich Soils of Bahariya Oases and their Effects on peanut Quality Australian Journal of Basic and Applied Sciences, 13(9): 66-91. DOI: 10.22587/ajbas.2019.13.9.7

\section{REFERENCES}

Abdurrahman H.; Fatih, B.; Fatih, M. and Mustafa, Y. (2004) Reclamation of Saline-Sodic Soils with Gypsum and MSW Compost. J. Compost Science \& Utilization, 12(2:175-179).

Adriano DC. (2001) Trace Elements in terrestrial environments: biogeochemistry, bioavailability and risks of metals, 2nd edn. Springer: New York; 866.

Afia, M. S. (2004) Metallic ores in Egypt: Resources, uses and needs; economic view, Symposium of Mineral Wealth and Development in Egyp" (5), p. 10, Al-Azhar University and Egyptian Society for Mining Services, Cairo, Egypt.

Ahmad,M., Rajapaksha, A.U., Lim, J.E., Zhang,M., Bolan, N., Mohan, D., et al., (2014) Biocha as a sorbent for contaminant management in soil and water: a review. Chemosphere 99, 19-33.

Alcordo IS, Rechcigl JE. (1993) Phosphogypsum in agriculture: a review. Advances in Agronomy 49: 55-118.

Amstrong ASB and Tanton TWT (1992) Gypsum applications to aggregated saline-sodic clay topsoils. J Soil Sci 43 : $249-260$.

Athmer, W., Weller, A. El Sayed, A.M.A., (2007) Petrological characterization of the Bahariya Formation, Egypt. In: Yossef, E. (ed): Cairo Univ., $2^{\text {nd }}$ International Conf. on the Geol. Of Tethys-2007, V 1: $179-184$.

Bae, S. and Lee, W. (2013) Biotransformation of lepidocrocite in the presence of quinines and flavins. Geochimica et Cosmochimica Acta. 114: 144155.

Bagreev A. Bandosz TJ. and Locke DC. (2001) Pore structure and surface chemistry of adsorbents obtained by pyrolysis of sewage-derived fertilizer. Carbon 39: 1971-1979.

Balintova, M.; Demcak, S.; Holub, M.; Hurakova, M. (2016) Study of Precipitates from Mine Water after Defrosting and Oxidation. Solid State Phenom. 244, 234-239. [CrossRef].

Basta NT, Ryan JA, Chaney RL. (2005) Trace element chemistry in residualtreated soils: key concepts and metal bioavailability. Journal of Environmental Quality 34: 49-63.

Basso AS, Miguez FE, Laird DA, Horton R, and Westgate M. (2013) Assessing potential of biochar for increasing water-holding capacity of sandy soils. GCB Bioenergy 5: 132-143.

Boateng A.A. (2007) Characterization and thermal conversion of charcoal derived from fluidized-bed fast pyrolysis oil production of switch grass. Industrial Engineering and Chemical Research 46: 8857-8862.

Bolan NS, Duraisamy VP (2003) Role of inorganic and organic soil amendments on immobilisation and phytoavailability of heavy metals: a review involving specifi c case studies. Australian Journal of Soil Research 41: 533-555.

Bolland MDA, Posner AM, Quirk JP (1977) Zinc adsorption by goethite in the absence and presence of phosphate. Australian Journal of Soil Research 15, 279-286.

Bouyoucos, G. J. (1962) Hydrometer method improved for making particle-size analyses of soils. Agronomy Journal 54:464-465.

Brodowski, S., Amelung, W., Haumaier, L., Abetz, C. and Zech, W. (2005) Morphological and chemical properties of black carbon in physical soil fractions as revealed by scanning electron microscopy and energy-dispersive x-ray spectrometry. Geoderma 128:116-129.

Buss, W., Graham, M.C., Shepherd, J.G., Masek, O., (2016) Suitability of marginal biomass derived biochars for soil amendment. Sci. Total Environ. 547, 314-322.

Cao, R. X, L. Q. Ma, M. Chen, S. P. Singh, and W. G. Harris. (2003) Phosphate-induced metal immobilization in a contaminated site. Environmental Pollution 122:19-28.

Caires, E. F. et al. (2004) Alterações químicas do solo eresposta do milho à calagem e aplicação de gesso. Revista Brasileira de Ciência do Solo, Viçosa, v.28, n. 1. p. 125-136.

Campitelli, P.S., Velasco, M.I. \& Ceppi, S.B., (2005) Chemical and physicochemical characteristics of humic acids extracted from compost, soil and amended soil. Talanta $69,1234-1239$.

Cárdenas-Aguiar, E., Gascó, G., Paz-Ferreiro, J., Méndez, A., (2017) The effect of biochar and compost from urban organic waste on plant biomass and properties of an artificially copper polluted soil. Int. Biodeterior. Biodegrad. 124, $223-232$.

Carvalho, J. M. et al. (2013) Produtividade de cana soca sem queima em função do uso de gesso e vinhaça. Pesquisa Agropecuária Tropical, Goiânia, v. 43, n. 1, p. 1-9.

Catuneanu, O.; M.A. khalifa b. and H.A. Wanas (2006) Sequence stratigraphy of the lower cenomanian bahariya formation, Bahariya Oasis, Western Desert, Egypt. Egypt. Sed. Geol., 190, 121-137.

Chapman HD, Pratt PF. Methods of Analysis for Soils, Plants and Waters. Univ. California Div. Agric. Sci. 1978; Priced Publication, Oakland.

Chen, B.L., Chen, Z.M., (2009) Sorption of naphthalene and 1-naphthol by biochars of orange peels with different pyrolytic temperatures. Chemosphere 76, 127-133.

Chen, Z. S., G. J. Lee, and J. C. Liu. (2000) The effects of chemical remediation treatments on the extractability and speciation of cadmium and lead contaminated soils. Chemosphere 41:235-242.

Chen, Y. and Schnitzer, M. (1978) The Surface Tension of Aqueous Solutions of Soil Humic Substances. Publication: Soil Science, vol. 125, issue 1, pp. 7-15. 1978.

Chojnacka K, Chojnacki A, Gorecka H. (2005) Biosorption of $\mathrm{Cr}^{3+}, \mathrm{Cd}^{2+}$ and $\mathrm{Cu}^{2+}$ ions by blue-green algae Spirulina sp.: Kinetics, equilibrium and the mechanism of the process. Chemosphere. 59: 75-84 
Citation: Sahar Mohamed Ismail; Sherine Shehata Marid and Doaa Taha Eissa Monitoring and Remediation of Environmental Aspects of Fe-rich Soils of Bahariya Oases and their Effects on peanut Quality Australian Journal of Basic and Applied Sciences, 13(9): 66-91. DOI: 10.22587/ajbas.2019.13.9.7

Ciobotă V.; N. Tarcea; W.Salama and P. Rösch (2012) Identification of minerals and organic materials in Middle Eocene ironstones from the Bahariya Depression in the Western Desert of Egypt by means of micro-Raman spectroscopy. J. Raman Spec., 43, 405-410.

Dai, Z., Zhang, X., Tang, C., Muhammad, N., Wu, J., Brookes, P.C., et al., (2017) Potential role of biochars in decreasing soil acidification - a critical review. Sci. Total Environ. 581-582, 601-611.

David P.P., Nelson P.V., Sanders D.C. (1994): A humic acid improves growth of tomato seedling in solution culture. Journal of Plant Nutrition, 17: 173-184.

Dragun, J. (1993) An Eh-pH reactor that simulates soil-groundwater systems. J. Soil Contam. 2:27-36.

El-Aref, M. M., Mesaed, A. A. and Salama, W. S. (2005) Stratigraphic setting, facies analysis and depositional environments of the Lutetian ironstones of Gabal Ghorabi mine area, ElBahariya Depression, Western Desert, Egypt. Proceedings of the 43rd Scientific Conference, December 2005, The Geological Society of Egypt, Cairo.

El-Hendawy, A.A., (2006) Variation in the FTIR spectra of a biomass under impregnation, carbonization and oxidation conditions. J. Anal. Appl. Pyrolysis 75(2), 159-166.

Farmer, V.C. (1974) Infrared Spectra of Minerals; Mineralogical Society: Great Britain \& Ireland, Volume 4, ISBN 9780903056533. [CrossRef].

FILIP, Z. \& BIELEK, P., (2002) Susceptibility of humic acids from soils with various contents of metal to microbial utilization and transformation. Biol. Fertil. Soils 36, 426-433.

Gemtos TA, Chouliaras N, Marakis S. (1999) Vinasse rate, time of application and compaction effect on soil properties and durum wheat crop. J Agric Eng Res. 73:283-296.

Gharaibeh MA, Eltaif NI, and Shunnar OF (2009) Leaching and reclamation of calcareous saline-sodic soil by moderately saline and moderate-SAR water using gypsum and calcium chloride. J Plant Nutr Soil Sci 172: 713-719.

Glaser B, Lehmann J, and Zech W. (2002) Ameliorating physical and chemical properties of highly weathered soils in the tropics with charcoal: A review. Biology and Fertility of Soils 35: 219-230.

Gul, S., Whalen, J.K., (2016) Biochemical cycling of nitrogen and phosphorus in biochar amended soils. Soil Biol. Biochem. 103, $1-15$.

Guo, J. and Chen, B., (2014) Insights on the molecular mechanism for the recalcitrance of biochar: interactive effects of carbon and silicon components. Environ. Sci. Technol. 48, 9103-9101.

Guo GL, Zhou QX, Ma LQ (2006) Availability and assessment of fixing additives for the in situ remediation of heavy metal contaminated soils: A review. Environmental Monitoring and Assessment 116: 513-528.

Gupta R, Saxena R, Mohapatra H, Ahuja P. (2002) Microbial variables for bioremediation of heavy metals from industrial effluents. In: Singh VP, Stapleton RD, editors. Progress in Industrial Microbiology, Vol. 36. Elsevier; P. 189-229

Hong, Y., A. Procto and J. Shultz, (2000) Acid-Treated Soy Hull Carbon Structure and Adsorption Performance. Journal of American Oil chemists' Society, 77(7): 785-790.

Hussain, S. I. (2000) Irrigation of crops with sewage effluent: Implication and movement of $\mathrm{Pb}$ and $\mathrm{Cr}$ as affected by soil texture, lime, gypsum, and organic matter. PhD thesis, Apartment of Soil Science, University of Agriculture, Faisalabad, Pakistan.

James B.R., Riha S.J. (1984): Soluble aluminium in acidified organic horizons of forest soils. Canadian Journal of Soil Science, 64: $637-646$.

Janus, A., Pelfrene, A., Heymans, S., Deboffe, C., Douay, F., Waterlot, C., (2015) Elaboration, characteristics and advantages of biochars for the management of contaminated soils with a specific overview on Miscanthus biochars. J. Environ. Manag. $162,275-289$.

Jarak M, Belic M, Govendarea M, Milosevic N, Djuric S. (2003) Effect of phosphogypsum and peat on microbiological and chemical properties of arenosol. Acta Biologica Yugoslavica Senija 52: 1-6.

Jiang, J., Peng, Y., Yuan, M., Hong, Z., Wang, D., Xu, R., (2015) Rice straw-derived biochar properties and functions as Cu(II) and cyromazine sorbents as influenced by pyrolysis temperature. Pedosphere 25, 781-789.

Joseph, S., Husson, O., Graber, E. R., van Zwieten, L., Taherymoosavi, S., Thomas, T., et al. (2015) the electrochemical properties of biochars and how they affect soil redox properties and processes. Agronomy, 5(3), 322-340.

Junakova, N.; Balintova, M. (2013) Nutrient Leaching from Reservoir Bottom Sediments. Chem. Eng. Trans. 35, $1141-1146$.

Kabata-Pendias A., Pendias H. (1992) Teace elements in soils and plants. $2^{\text {nd }}$ edition. CRC Press Inc. Boca Raton, Florida.

Kaya, M., Kucukyumuk Z., Erdal, I. (2009) Effects of elemental sulfur and sulfur-containing waste on nutrient concentrations and growth of bean and corn plants grown on calcareous soil. African journal of biotechnology, 8: 448 - 449.

Kayser, A., Wenger, K., Keller, A., Attinger, W., Fellix, H.R. and Gupta, S.K. (2000) Enhancement of phytoextraction of Zn, Cd and $\mathrm{Cu}$ from calcareous soil: the use of NTA and sulphur amendments. Environ. Sci. Technol., 34, $1778-1783$.

Khademi A, Z., D.L. Jones, C.M.J. Malakouti, F. Asadi and M. Ardebili (2009) Organic acid mediated nutrient extraction efficiency in three calcareous soils. Australian J. Soil Res., 47:213-220.

Khater, A.M.H. (1981) A study of sulphur and petroleum by products as efficient materials affecting the availability of certain nutrient in soils. M.Sc. thesis, Fac. Of Agric., Ain Shams Univ.

Kumar PBAN, Dshenkov V, Mooto H and Raskin (1995) Phytoextraction: the use of plants to remove heavy metals from soils. Environ Sci. Technol, 29: 1232-8.

Kumpiene, J., A. Lagerkvist, and C. Maurice. (2008) Stabilization of As, Cr, Cu, Pb, and $\mathrm{Zn}$ in soil using amendments: A review. Waste Management 28:215-225. 
Citation: Sahar Mohamed Ismail; Sherine Shehata Marid and Doaa Taha Eissa Monitoring and Remediation of Environmental Aspects of Fe-rich Soils of Bahariya Oases and their Effects on peanut Quality Australian Journal of Basic and Applied Sciences, 13(9): 66-91. DOI: 10.22587/ajbas.2019.13.9.7

Lahori, A.H., Guo, Z., Zhang, Z., Li, R., Mahar, A., Awasthi,M.K., et al., (2017) Use of biochar as an amendment for remediation of heavy metal-contaminated soils: prospects and challenges. Pedosphere 27, 991-1014

Lee CH, Ha BY, Lee YB, Kim PJ. (2009) Effect of alkalized PG on soil chemical and biological properties. Communications in Soil Science \& Plant Analysis 40: 2072-2086.

Liu C. (1998): Effects of humic substances on creeping bentgrass growth and stress tolerance. [Ph.D. Thesis.] Philosophy Department of Crop Science, North Carolina State University, Raleigh.

Lu, H., Zhang, Y. Y., Huang, X., Wang, S., \& Qiu, R. (2012) Relative distribution of Pb2? Sorption mechanisms by sludgederived biochar. Water Research, 46(3), 854-862. doi:10.1016/j.watres.2011.11.058.

Macek T, Mackova M. (2011) Potential of biosorption technology. In: Microbial Biosorption of Metals. Netherlands: Springer;. p. 7-17.

Mansour, S.F; Mohamedin, A.A.M. and Mahmoud, M.M. (2011) Evaluation of some soil amendments and their applied methods on the reclamation of saline-sodic soils. J. of Biological Chemistry Environmental Sci.,6 (4):167-181.

Marel, H.M.V. and H. Bentelspacher, (1976) Atlas of infrared spectroscopy of clay minerals and their admixtures. New York: Elsevier Science Publishers.

Martinez, C.E. and Motto, H.L. (2000) Solubility of lead and copper added to mineral soils. Environ. Pollut. $107,153-158$.

Mckeague, J.A. (ed.) (1978) In Manual on soil sampling and methods of analysis. Canadian Society of soil science: 66-68.

Mclaughlin M.J., Tiller K.G., Neidu R., Stewers DE (1996) Review: The behavior and environmental impact of contaminants in fertilizers. Australian Journal of soil Research 34: 1- 54.

Mclean, E.O. (1982) Soil pH and time requirement. P. 199-224, In: A.L. Page (ed.) Methods of soil analysis, Part 2: chemical and microbiological properties. Am. Soc. Agron., Madison, Wise., USA.

Méndez, A., Paz-Ferreiro, J., Araujo, F., Gascó, G., (2014) Biochar from pyrolysis of deinking paper sludge and its use in the treatment of a nickel polluted soil. J. Anal. Appl. Pyrolysis

107, 46-52.

Michalovicz, L. et al. (2014) Soil fertility, nutrition and yield of maize and barley with gypsum application on soil surface in notill. Revista Brasileira de Ciência do Solo, Viçosa, v. 38, n. 5, p. 1496-1505,

Mishra A, Sharma SD, Khan GH (2003) Improvement in physical and chemical properties of sodic soil by 3, 6, and 9 years old plantation of Eucalyptus tereticonis biorejuvenation of sodic soil. Forest Ecol Manage 184: 115-124.

Moisés, M.P., C.T. Pereirada Silva, J.G. Meneguin, E.M. Girotto and E. Radovanovic, (2013) Synthesis of zeolite NaA from sugarcanebagasseash. Materials Letters, 108: 43-246.

Nardi, S., D. Pizzeghello, A. Muscolo, and A. Vianello. (2002) Physiological effects of humic Substances on higher plants. Soil Biology and Biochemistry 34:1527-1536.

Nakmo To. K. (1986) Infrared and Raman Spectra of Inorganic and Coordination Compounds. Fourth Edition. Wiley. New York. pp. 536 .

Nelson, D. W., and L. E. Sommers. (1982) Total carbon, organic carbon, and organic matter. In Methods of soil analysis, part 2: Chemical and microbiological properties, 2nd ed., ed. A. L. Page et al., 539-577. Madison, Wisc. ASA.

Page AL, Miller DR, Keeney Ed. (1982) Methods of soil analysis, 2. Chemical and microbiological properties; 2rd ed. New York.

Parr, J. F. (2006) Effect of fire on phytolith coloration, Geoarcheology, 21, 171-185.

Pauletti, V. et al. (2014) Efeitos em longo prazo da aplicação de gesso e calcário no sistema de plantio direto. Revista Brasileira de Ciência do Solo, Viçosa, v. 38, n. 2, p. 495-505.

Qadir M, Noble AD, Chartres C. (2013) Adapting to climate change by improving water productivity of soil in dry areas. Land Degradation \& Development 24: 12-21. DOI: 10.1002/ldr.1091.

Raynaud, S.; Champion, E.; Bernache-Assollant, D.; Thomas, P. (2002) Calcium phosphate apatites with variable Ca/P atomic ratio I. Synthesis, characterisation and thermal stability of powders. Biomaterials. 23, 1065-1072. [CrossRef].

Rhoades, J. D. (1982) Cation exchange capacity. In Methods of soil analysis, part 2: Chemical and microbiological properties, 2nd ed., ed. A. L. Page et al., 149-157. Madison, Wisc. : ASA.

Richards, L.A., (1954) Diagnosis and improvement of saline and alkali soils. USDA Agric. Handbook Washington D.C.

Roden, E. E. and Zachara, J. M. 1996. Microbial Reduction of Crystalline Iron (III) Oxides: Influence of Oxide Surface Area and Potential for Cell Growth. Environ. Sci. Technol. 30:1618-1628.

Ruff S.W. et al. (1997) Development of thermal infrared emission spectroscopy for geological investigations of earth and mars. JGR, 102: 14899-14913.

Rutherford PM, Dudas MJ, Samek RA. (1994) Environmental impacts of phosphogypsum. Science of the Total Environment 99: 1-38.

Saifullah, Dahlawi S., Naeem, A., Rengel, Z., Naidu, R., (2018) Biochar application for the remediation of salt-affected soils: challenges and opportunities. Sci. Total Environ. 625, 320-335.

Saito M. and Marumoto T. 2002. Inoculation with arbuscilar mycorrhizal fungi: The status quo in Japan and the future prospects. Plant and Soil 244: 273-279.

Salama W.; M.M. El Aref and R. Gaupp (2013) Mineral evolution and processes of ferruginous microbialite accretion - an example from the Middle Eocene stromatolitic and ooidal ironstones of the Bahariya Depression, Western Desert, Egypt. Geobiol, 11, 15-28.

SAS Institute, (1996)The SAS System for Windows; Release 6. 12; Statistical Analysis System Institute, Inc., Cary, NC. 
Citation: Sahar Mohamed Ismail; Sherine Shehata Marid and Doaa Taha Eissa Monitoring and Remediation of Environmental Aspects of Fe-rich Soils of Bahariya Oases and their Effects on peanut Quality Australian Journal of Basic and Applied Sciences, 13(9): 66-91. DOI: 10.22587/ajbas.2019.13.9.7

Serra, J.; González, P.; Liste, S.; Serra, C.; Chiussi, S.; León, B.; Pérez-Amor, M.; Ylänen, H.O.; Hupa, M. FTIR and XPS (2003) Studies of bioactive silica based glasses. J. Non-Cryst. Solids, 332, 20-27. [CrossRef].

Singh, O. V., S. Labana, G. Pandey, and R. Budhirahja. (2003) Phytoremediation: An overview of metallic ion decontamination from soil. Applied Microbiology and Biotechnology 61:405-412.

Singh, J.P., Marwaha, R.S., and Srivastaava O.P. (1995) Processing and nutritive qualities of potato tuber as affected by fertilizer nutrients and sulphur application. J. Indian Potato. Ass. 22 (1-2): 32 -37.

Soltanpour, P. N. (1985) Use of ammonium bicarbonate DTPA test to evaluate elemental availability and toxicity. Communications in Soil Science and Plant Analysis 16:323-338.

Soon YK (1981) Solubility and sorption of Cadmium in soils amended with sewage sludge. Journal of Soil Science 32, 85-95.

Steiner, C., Teixeira, W.G., Lehmann, J., Nehls, T., Blum, W.E.H., Zech, W., (2007) Long term effects of manure, charcoal and mineral fertilization on crop production and fertility on a highly weathered Central Amazonian upland soil. Plant Soil 291, 275-290.

Suganya, S., Sivasamy, R., (2006) Moisture retention and cation exchange capacity of sandy soil as influenced by soil additives. J. Appl. Sci. Res. 2, 949-951.

Sun, K., Ro, K., Guo, M., Novak, J., Mashayekhi, H., Xing, B., 2011. Sorption of bisphenol A, 17 $\alpha$-ethinyl estradiol and phenanthrene on thermally and hydrothermally produced biochars. Bioresour. Technol. 102, 5757-5763.

Suresh, B.N. and B.S.V. Reddy, (2011) Dried Sugarcane Press Residue as a Potential Feed Ingredient Source of Nutrients for Poultry. Asian-Aust. Journal of Animal Science, 24(11): 1595-1600.

Tanner L.H. and M.A. Khalifa (2010) Origin of ferricretes in fluvial-marine deposits of the lower cenomanian bahariya formation, bahariya oasis, western desert, Egypt. J. Afr. Earth Sci., 56, 179-189.

Tichy, R., Fajtl, J., Kuzel, S. and Kolar, L. (1997) Use of elemental sulphur to enhance a cadmium solubilization and its vegetative removal from contaminated soil. Nut. Cycl Agroecosyst. 46, 249 - 255.

Troeh FR. and Thompson LM. (2005) Soils and Soil Fertility. Iowa, USA: Blackwell Publishing. Wong SC, Li XD, Zhang G, Qi SH, and Min Y.S. 2002. Heavy metals in agricultural soils of the Pearl River Delta, South China. Environ. Pollut. 119:33-44.

Uchimiya, M., Chang, S., \& Klasson, K. T. (2011) Screening biochars for heavy metal retention in soil: Role of oxygen functional groups. Journal of Hazardous Materials, 190(1-3), 432-441.

Uchimiya, M., Lima, I. M., Klasson, K. T., \& Wartelle, L. H. (2010) Contaminant immobilization and nutrient releaseby biochar soil amendment: Roles of natural organic matter. Chemosphere, 80(8), 935-940.

Williamson, A. J., Morris, K., Shaw, S., Byrne, J.M., Boothman, C. and Lloyd, J.R., (2013) Microbial Reduction of Fe (III) under Alkaline Conditions Relevant to Geological Disposal. Appl. Environ. Microbiol. 79(11): 3320 - 3326.

Wu F, Sun F, Wu S, Yan Y, Xing B. (2012) Removal of antimony (III) from aqueous solution by freshwater Cyanobacteria microcystis biomass. Chemical Engineering Journal. 183: 172-179

Wu, W., Yang, M., Feng, Q., McGrouther, K., Wang, H., Lu, H., and Chen, Y. (2012) Chemical characterization of rice strawderived biochar for soil amendment, Biomass Bioenerg., 47, 268-276.

Wu Che-Ming, Lin Chun- (2005) I. Decomposition of Calcium Carbonate in the Temperature Range 1180-1353 K. Journal of Chemical Engineering of Japan. 38(9), 734.

Xiong, Z. T. (1997) Bioaccumulation and physiological effects of excess lead in a roadside pioneer species Sonchus oleraceus L. Environmental Pollution 97:275-279.

Xu, Y., Fang, Z., (2015) Advances on remediation of heavy metal in the soil by biochar. Environ. Eng. 33, $156-159$.

$\mathrm{Xu}$ Y, Schwartz FW, Traina SJ (1994) Sorption of $\mathrm{Zn}^{2+}$ and $\mathrm{Cd}^{2+}$ on hydroxyapatite surfaces. Environmental Science and Technology 28, $1472-1480$.

Yassen AA, Arafat SM, Zaghloul SM. (2002) Maximizing use of vinasse and filter mud as byproducts of sugar cane on wheat productions. J Agric Sci Mansoura Univ. 27:7865-7873.

Zabaniotou A, Stavropoulos G. and Skoulou V. (2008) Activated carbon from olive kernels in a twostage process: Industrial improvement. Bioresource Technology 99: 320-326.

Zambrosi, F. C. B.; Alleoni, L. R. F.; Caires, E. F. (2007) Aplicação de gesso agrícola e especiação iônica da solução de um Latossolo sob sistema plantio direto. Ciência Rural, Santa Maria, v. 37, n. 1, p. 110-117.

Zheng, R.L., Cai, C., Liang, J.H., Huang, Q., Chen, Z., Huang, Y.Z., Arp. H.P.H., Sun, G.X. (2012) The effects of biochars from rice residue on the formation of iron plaque and the accumulation of $\mathrm{Cd}, \mathrm{Zn}, \mathrm{Pb}$, As in rice (Oryza sativa $\mathrm{L}$.) seedlings. Chemosphere 89 (7), $856-862$.

Zientara M. (1983) Effect of sodium humate on membrane potential in internodal cells of Nitellopsis obtuse. Acta Societatis Botanicorum Poloniae, 52: 271-277. 